\title{
28. EOCENE TO PLEISTOCENE SILICOFLAGELLATES FROM THE NORWEGIAN-GREENLAND SEA (DSDP LEG 38)
}

\author{
Erlend Martini and Carla Müller, Geologisch-Paläontologisches Institut der Universität, \\ Frankfurt am Main, Germany
}

\section{INTRODUCTION}

During Leg 38 of the Deep Sea Drilling Project, 17 sites (336 to 352 ) were occupied in the NorwegianGreenland Sea (Figure 1). Material from most sites yielded silicoflagellates, although they were not represented at all sites. Intervals containing silicoflagellates include the middle Eocene to Quaternary. Unfortunately older sediments which, on the basis of silicoflagellates, may indicate direct correlation to diatomaceous deposits in the Paleocene/lower Eocene interval of the North Sea basin, especially Denmark and northern Germany, were not recovered during this cruise.

Since calcareous nannoplankton, which is commonly used for primary age determination, in these high latitudes is only present in sufficient numbers and diversified assemblages in a few horizons, and otherwise show rather meager assemblages with longranging species, the first age determinations are based mainly on silicoflagellates. Silicoflagellates proved to be the most important fossil group along with diatoms in this region. Although the worldwide distribution of most species and their tendency to develop regional "varieties" is still incompletely known, data from the Deep Sea Drilling Project material add a great deal to the understanding of the silicoflagellate distribution and evolution. Meanwhile, the first publication on the silicoflagellates of the Ehrenberg Collection has been published by Locker (1974), and it seems that quite a few commonly used silicoflagellate names have to be altered to avoid further confusion. In this paper, the Ehrenberg silicoflagellate types as illustrated by Locker (1974) are the basis for identification.

\section{LOCALITIES AND ASSEMBLAGES RECOVERED}

Geographical position of the DSDP holes drilled during Leg 38 are shown in Figure 1; and listed in Table 1 of Chapter 1 (this volume). With the exception of Sites 344, 347, 349, 351, and Holes 352 and 352A, silicoflagellates were generally encountered in certain intervals from the remaining holes. On the Iceland Plateau (Site 348) and Jan-Mayen Ridge (Sites 346 and 350) silicoflagellates were found only in the middle Miocene to Pliocene portions of the cored succession. In the Norway Basin (Site 337) silicoflagellates were encountered in the early Oligocene, whereas on the IcelandFaeroe Ridge (Site 336) they are present only in the late Oligocene and lowest Miocene and on the Mohns Ridge (Site 345). They are present from the late Oligocene to the middle Miocene. Site 338 on the Outer V $\phi r-$ ing Plateau yielded the best silicoflagellate succession with assemblages from the upper Eocene to the upper Miocene. At Sites 339 and 340 on the Inner V $\phi$ ring Plateau silicoflagellate assemblages from the late Eocene and early Oligocene were recovered. Miocene to Pliocene assemblages were found in the two remaining holes on the V $\phi$ ring Plateau (Sites 341 and 342). The oldest silicoflagellate assemblages (early middle Eocene) were recovered at Site 343 in the Lofoten Basin.

Concurrent with the increase in the deposition of glacial material in the late Pliocene, a sudden occurrence of reworked late Paleogene and early Miocene silicoflagellates was noted at Sites 336 (Iceland-Faeroe Ridge), 339 and 341 (V $\phi$ ring Plateau), and at Site 343 (Lofoten Basin). A summary of silicoflagellate zones identified in the present material is given in Figure 2.

\section{SILICOFLAGELLATE ZONATION IN THE NORWEGIAN-GREENLAND SEA}

The silicoflagellate zonation used in this report for the early Eocene to Middle Miocene interval is virtually the same as outlined in Martini $(1971,1972,1974)$ with necessary correction in the upper Eocene (Figure 3). For the late Miocene to Quaternary interval, a combination of zones suggested by Ling (1973) and Bukry (1973) for North Pacific sediments is used. The zonation is summarized in Figure 3 together with correlations to the standard nannoplankton zonation (Martini, 1971), and includes the following zones:

\section{Dictyocha transitoria Zone}

Definition: Interval from the first to the last occurrence of Dictyocha transitoria Deflandre.

Author: Martini, 1974.

Common species: Dictyocha transitoria Deflandre, Naviculopsis minor (Schulz).

Remarks: Not recovered in the present material.

\section{Naviculopsis minor Zone}

Definition: Interval from the last occurrence of Dictyocha transitoria Deflandre to the first occurrence of Corbisema bimucronata Deflandre.

Author: Martini, 1974.

Common species: Corbisema spinosa Deflandre, Corbisema apiculata (Lemmermann), Dictyocha rotundata Jousé, Distephanus quinquangellus Bukry and Foster, Naviculopsis foliacea Deflandre, and Naviculopsis minor (Schulz).

Remarks: Present at Site 343, Cores 5 and 6.

\section{Naviculopsis foliacea Zone}

Definition: Interval from the first occurrence of Corbisema bimucronata Deflandre to the first occurrence of Dictyocha quadria (Mandra). 


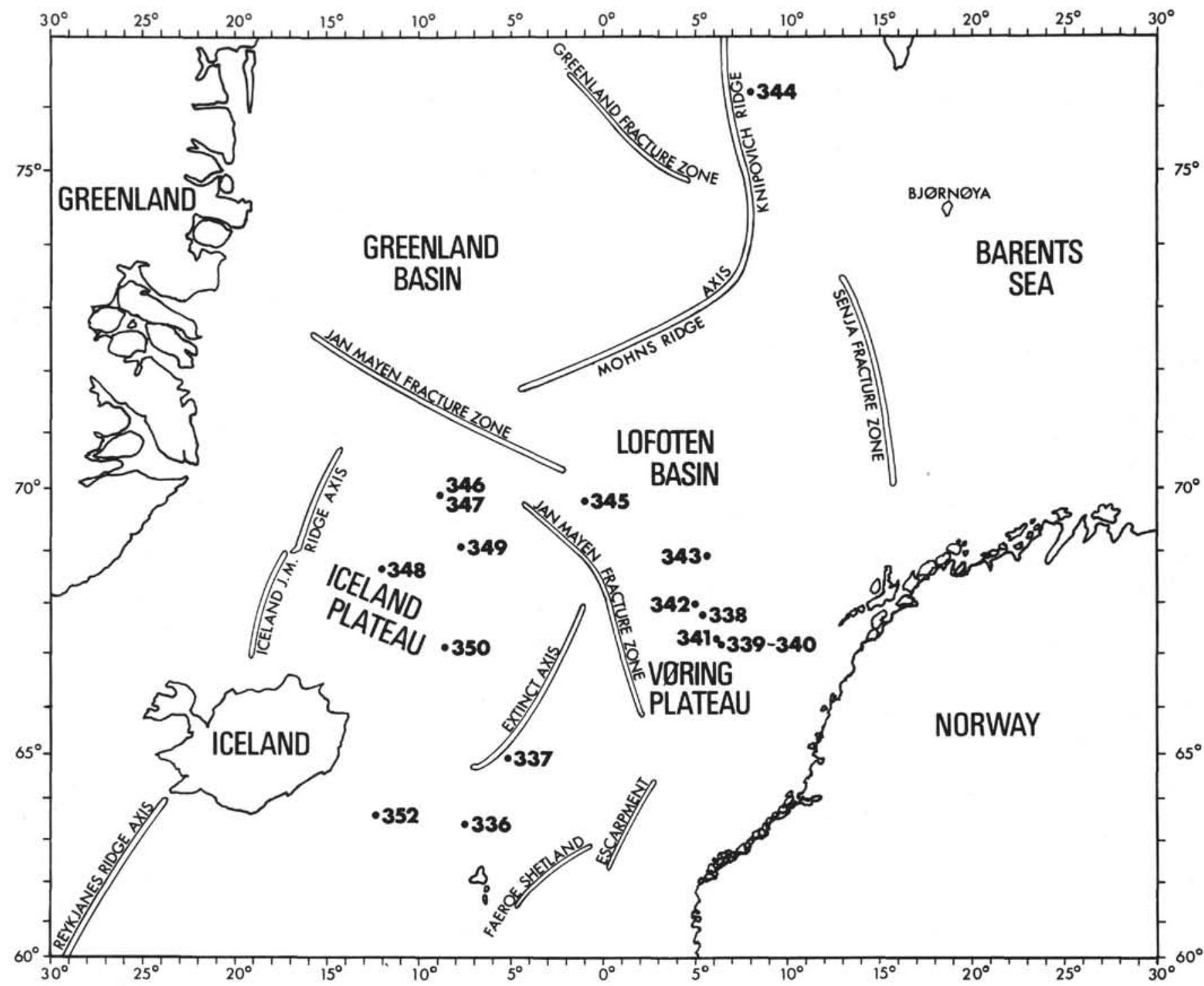

Figure 1. Sites occupied during Leg 38 in the Norwegian-Greenland Sea.

Author: Martini, 1971, emended this paper.

Common species: Mesocena oamaruensis Schulz, Naviculopsis foliacea Deflandre, Distephanus quinquangellus Bukry and Foster, Corbisema spinosa Deflandre, Corbisema bimucronata Deflandre, Phyllodictyocha schulzii Deflandre, Corbisema apiculata (Lemmermann).

Remarks: Probably recovered at Site 340, Samples 3, $\mathrm{CC}$ to $5, \mathrm{CC}$.

\section{Corbisema bimucronata Zone}

Definition: Interval from the first occurrence of Dictyocha quadria (Mandra) to the first occurrence of Mesocena apiculata (Schulz).

Author: Martini, 1974, emended this paper.

Common species: Dictyocha quadria (Mandra), Corbisema apiculata (Lemmermann), Mesocena oamaruensis Schulz, Corbisema spinosa Deflandre, Naviculopsis ponticula Perch-Nielsen, Corbisema flexuosa (Stradner), and Corbisema bimucronata Deflandre.

Remarks: In the present material, found at Site 338 , Cores 27 to 29, and Site 340 , Cores 1 to 3,6 to 11 .
Dictyocha quadria Zone

Definition: Interval from the first occurrence of Mesocena apiculata (Schulz) to the last occurrence of Dictyocha quadria (Mandra).

Authors: Martini and Müller, this paper.

Common species: Dictyocha quadria (Mandra), Corbisema apiculata (Lemmermann), Corbisema spinosa Deflandre, Naviculopsis biapiculata (Lemmermann), Mesocena apiculata (Schulz), Dictyocha frenguellii Deflandre.

Remarks: In the present material, found at Site 338, Core 26.

\section{Naviculopsis biapiculata Zone}

Definition: Interval from the last occurrence of Dictyocha quadria (Mandra) to the first occurrence of Naviculopsis lata (Deflandre).

Author: Martini, 1974, emended this paper.

Common species: Naviculopsis biapiculata (Lemmermann), Mesocena apiculata (Schulz), Distephanus crux (Ehrenberg), Cannopilus hemisphaericus (Ehrenberg). 
TABLE 1

Silicoflagellates in Selected Samples from Site 338 Representing the Upper Eocene to Middle Miocene Interval

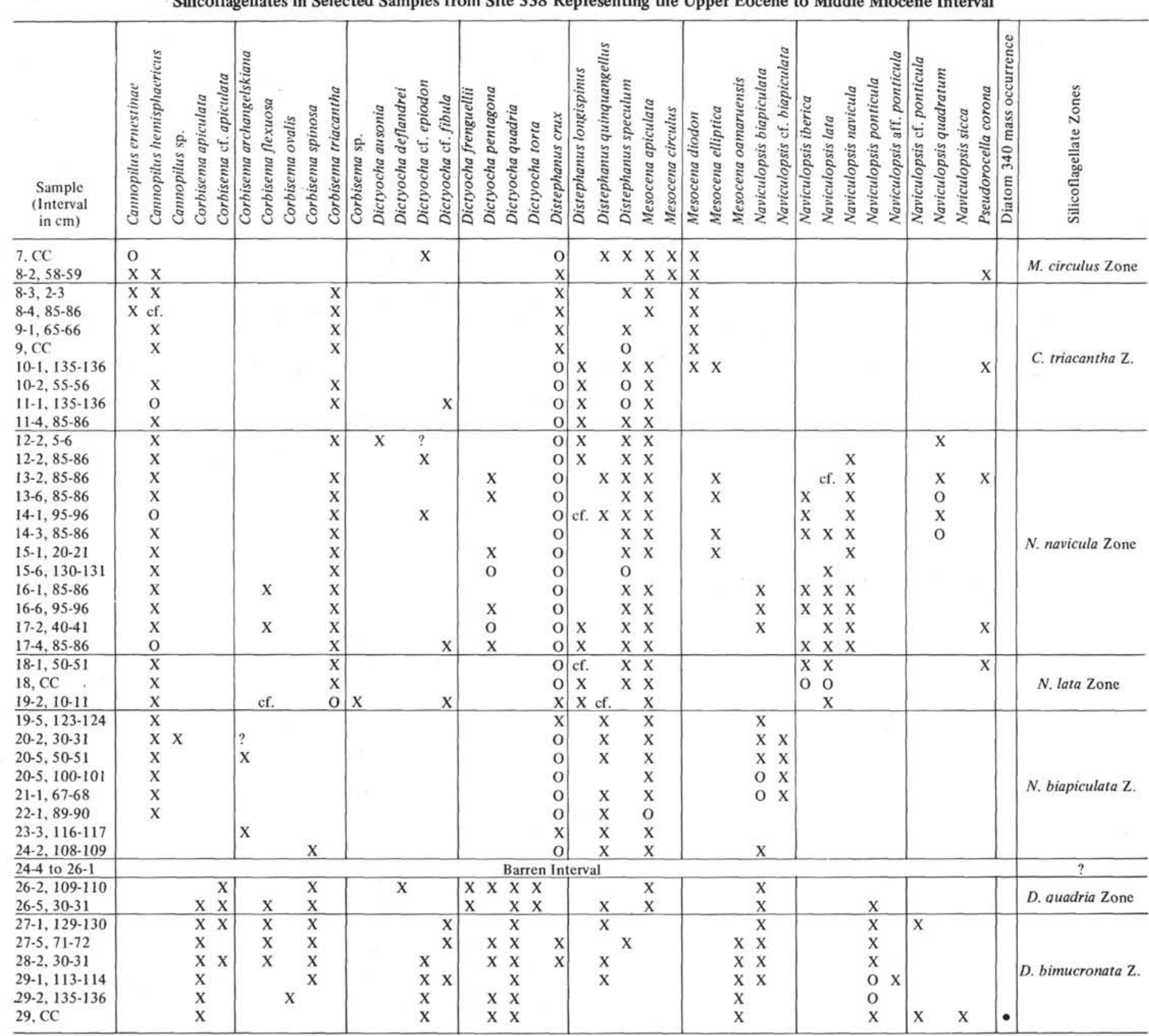

Note: $\mathrm{X}=$ rare to few, $\mathrm{O}=$ common or dominant, $\bullet=$ mass occurrence of diatom 340 (=Triceratium barbadense $)$ 
TABLE 2

Silicoflagellates in Selected Samples from Site 339 Representing Part of the Early Oligocene and Part of the Glacial Interval

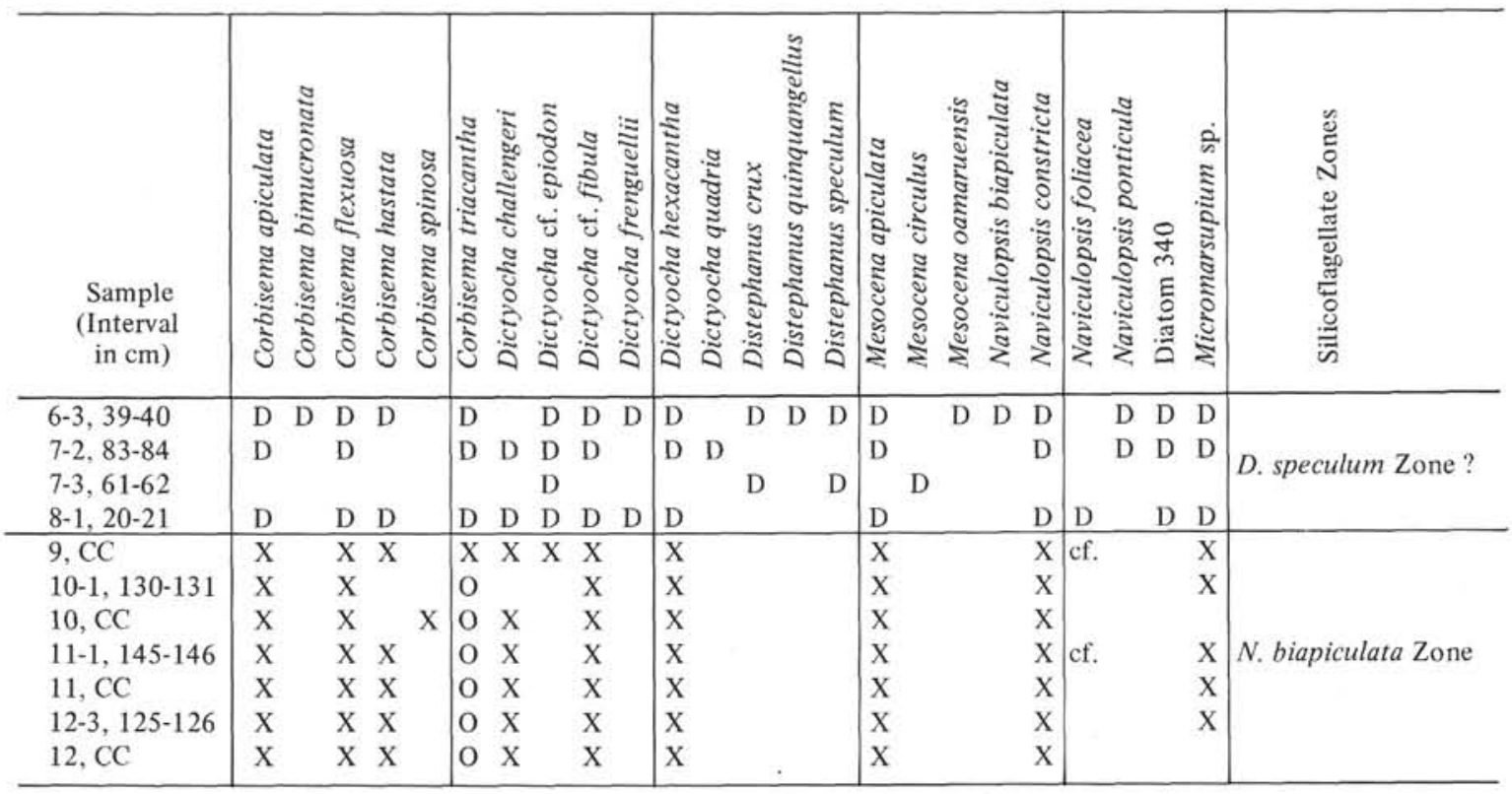

Note: $\mathrm{X}=$ rare to few, $\mathrm{O}=$ common or dominant, $\mathrm{D}=$ displaced from older strata.

Remarks: In the present material, found at Site 337, Cores 9 to 12, Site 338, Cores 19 to 24 , and Site 339, Cores 9 to 12 .

\section{Naviculopsis lata Zone}

Definition: Interval from the first occurrence of Naviculopsis lata (Deflandre) to the first occurrence of Naviculopsis navicula (Ehrenberg).

Author: Martini, 1972.

Common species: Naviculopsis lata (Deflandre), Distephanus crux (Ehrenberg), Mesocena apiculata (Schulz), Cannopilus hemisphaericus (Ehrenberg), Corbisema triacantha (Ehrenberg), Distephanus speculum (Ehrenberg), Naviculopsis iberica Deflandre.

Remarks: In the present material, found at Site 336, Cores 15 and 16, Site 338, Cores 18 and 19, Site 342, Core 6, Site 345, Cores 9 and 10.

\section{Naviculopsis navicula Zone}

Definition: Interval from the first occurrence of Naviculopsis navicula (Ehrenberg) to the last occurrence of Naviculopsis quadratum (Ehrenberg) [syn. $N$. rectangularis (Schulz)].

Author: Martini, 1972.

Common species: Naviculopsis navicula (Ehrenberg), Naviculopsis iberica Deflandre, Distephanus crux (Ehrenberg), Corbisema triacantha (Ehrenberg), Cannopilus hemisphaericus (Ehrenberg), Corbisema flexuosa (Stradner), Mesocena apiculata (Schulz), and in the upper part Naviculopsis quadratum (Ehrenberg) [syn. $N$. rectangularis (Schulz)].

Remarks: In the present material, found at Site 338, Cores 12 to 17, Site 342, Core 6, and Site 345, Core 8 .

\section{Corbisema triacantha Zone}

Definition: Interval from the last occurrence of Naviculopsis quadratum (Ehrenberg) to the last occurrence of Corbisema triacantha (Ehrenberg).
Author: Martini, 1971.

Common species: Distephanus crux (Ehrenberg), Mesocena apiculata (Schulz), Distephanus speculum (Ehrenberg), Cannopilus hemisphaericus (Ehrenberg), Distephanus longispinus (Schulz), Corbisema triacantha (Ehrenberg), and in the upper part Mesocena diodon Ehrenberg.

Remarks: In the present material, found at Site 338, Cores 8 to 11 , Site 342 , Cores 3 to 5 , Site 345 , Cores 6 to 7(?), Site 346 , Cores 5 and 6.

\section{Mesocena circulus Zone}

Definition: Interval from the last occurrence of Corbisema triacantha (Ehrenberg) to the last occurrence of Mesocena circulus (Ehrenberg).

Author: Ling, 1973, emended this paper.

Common species: Mesocena circulus Ehrenberg, Mesocena diodon Ehrenberg, Cannopilus hemisphaericus (Ehrenberg), Dictyocha cf. epiodon Ehrenberg, Distephanus speculum (Ehrenberg), Distephanus quinquangellus Bukry and Foster, Cannopilus ernestinae Bachmann, and in the lower part Mesocena apiculata (Schulz), and Distephanus longispinus (Schulz).

Remarks: In the present material found at Site 338, Cores 7 and 8 , Site 341 , Cores 25 to 34 , and Site 348, Cores 11 to 18 .

\section{Distephanus boliviensis Zone}

Definition: Interval from the last occurrence of Mesocena circulus (Ehrenberg) to the last occurrence of Distephanus boliviensis (Frenguelli).

Author: Bukry and Foster, 1973, emended this paper.

Common species: Distephanus speculum (Ehrenberg), Distephanus boliviensis (Frenguelli), Distephanus quinquangellus Bukry and Foster, Distephanus crux (Ehrenberg), and in the lower part Mesocena diodon Ehrenberg. 


\begin{tabular}{|c|c|c|c|c|c|c|c|c|c|c|c|c|}
\hline & $\begin{array}{l}\text { Silicoflagellate } \\
\text { Zones }\end{array}$ & 336 & 337 & 338 & 339 & 340 & 341 & 342 & 343 & 345 & 346 & 348 \\
\hline \multicolumn{13}{|l|}{ Quat. } \\
\hline \multirow{2}{*}{ Plio. } & D. specutum Zone & $8-9 ?$ & & & $\star(6-8)$ & *(1) & *(4-7) & & *(3) & & & 5 \\
\hline & D. boliviensis $Z$. & & & & & & & & & & & $6-10$ \\
\hline \multirow{3}{*}{ 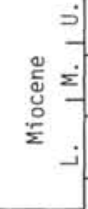 } & M. circulus Zone & & & $7-8$ & & & $25-34$ & & & & & $11-18$ \\
\hline & c. triacantha Zone & & & $8-11$ & & & & $3-5$ & & $6-7 ?$ & $5-6$ & \\
\hline & N. navieula Zone & & & $12-17$ & & & & 6 & & 8 & & \\
\hline \multirow{2}{*}{$\begin{array}{l}\dot{0} \\
\dot{0} \\
\dot{0}\end{array}$} & N. Lata Zone & $15-16$ & & $18-19$ & & & & 6 & & $9-10$ & & \\
\hline & N. Biapiculata Z. & & $9-12$ & $19-24$ & $9-12$ & & & & & & & \\
\hline \multirow{5}{*}{ 岕 } & D. quadria Zone & & & 26 & & & & & & & & \\
\hline & c. bimucronata $Z$. & & & $27-29$ & & \begin{tabular}{|c|}
$8-11$ \\
$1-3,6-8$ \\
\end{tabular} & & & & & & \\
\hline & N. foliacea Zone & & & & & $3-5 ?$ & & & & & & \\
\hline & N. mingor Zone & & & & & & & & $5-6$ & & & \\
\hline & D. transitoria $Z$. & & & & & & & & & & & \\
\hline & & & & & & & & & & & & \\
\hline
\end{tabular}

Figure 2. Silicoflagellate zones found in cores recovered in holes drilled during Leg 38. Brackets with star indicate reworked assemblages from the late Eocene to early Miocene redeposited during "glacial" time (probably in the Distephanus speculum Zone.

Remarks: In the present material found at Site 348 Cores 6 to 10 .

\section{Distephanus speculum Zone}

Definition: Interval from the last occurrence of Distephanus boliviensis (Frenguelli) to the first occurrence of Distephanus octangulatus Wailes.

Author: Bukry, 1975, emended this paper.

Common species: Distephanus speculum (Ehrenberg), Distephanus octonarius (Ehrenberg).

Remarks: In the present material found at Site 336, Cores 8, 9, Site 348, Core 5. Reworked silicoflagellates from the upper Eocene to lower Miocene, masking the autochthonous assemblage, are present at Site 339, Cores 6 to 8 , Site 340 , Core 1, Site 341 , Cores 4 to 7 , Site 343, Core 3, which may belong to the Distephanus speculum Zone.

The youngest sediments at the sites above the $D i$ stephanus speculum Zone were barren of silicoflagellates, and the high latitude species Distephanus octangulatus Wailes has not been found. The first occurrence of this species was used by Ling to define the late Pleistocene to recent Distephanus octangulatus Zone in the North Pacific. It is assumed that this zone is represented at Site 348 by unfossiliferous sediments (Cores 3 and 4) and by nannoplankton (Zone NN 21) bearing sediments in Cores 1 and 2.

Perch-Nielsen (in press) recently suggested two silicoflagellate zones in the Norwegian Sea based on a piston core (Vema 28/43) from the V $\phi$ ring Plateau.

The Naviculopsis vemae Zone (interval from the first to the last occurrence of Naviculopsis vemae Perch-
Nielsen) and the Naviculopsis ponticula Zone (last occurrence of Naviculopsis vemae Perch-Nielsen to the last occurrence of Naviculopsis ponticula Perch-Nielsen). The position of these zones in the zonation used on Leg 38 is not entirely known, as Naviculopsis vemae was not encountered in the material recovered on the V $\phi$ ring Plateau, and Naviculopsis ponticula seems to range probably from the Naviculopsis foliacea Zone to the higher part of the Dictyocha quadria Zone, with a maximum in the Corbisema bimucronata Zone. However, in the assemblage present in her Naviculopsis vemae Zone, Perch-Nielsen listed "Septamesocena" apiculata which has its first occurrence at the base of the Dictyocha quadria zone, restricting the Naviculopsis vemae Zone to a level within the Dictyocha quadria Zone, which is, however, not in accordance with the occurrence of Naviculopsis ponticula.

\section{CORRELATION TO THE NANNOPLANKTON ZONATION}

Correlation of the present material to the standard nannoplankton zonation is rather restricted as only a few horizons contain datable nannoplankton assemblages (Müller, this volume). Correlations shown in Figure 3 are based on other previously published data. The following nannoplankton zones have been determined, and can be used for correlation of the silicoflagellate assemblages. The Recent to late Pleistocene zone (NN 21) is present in Cores 1 and 2 of Site 348 $(0.0-18.5 \mathrm{~m})$. Cores 3 and 4 are barren of calcareous nannoplankton and silicoflagellates. The latter first 


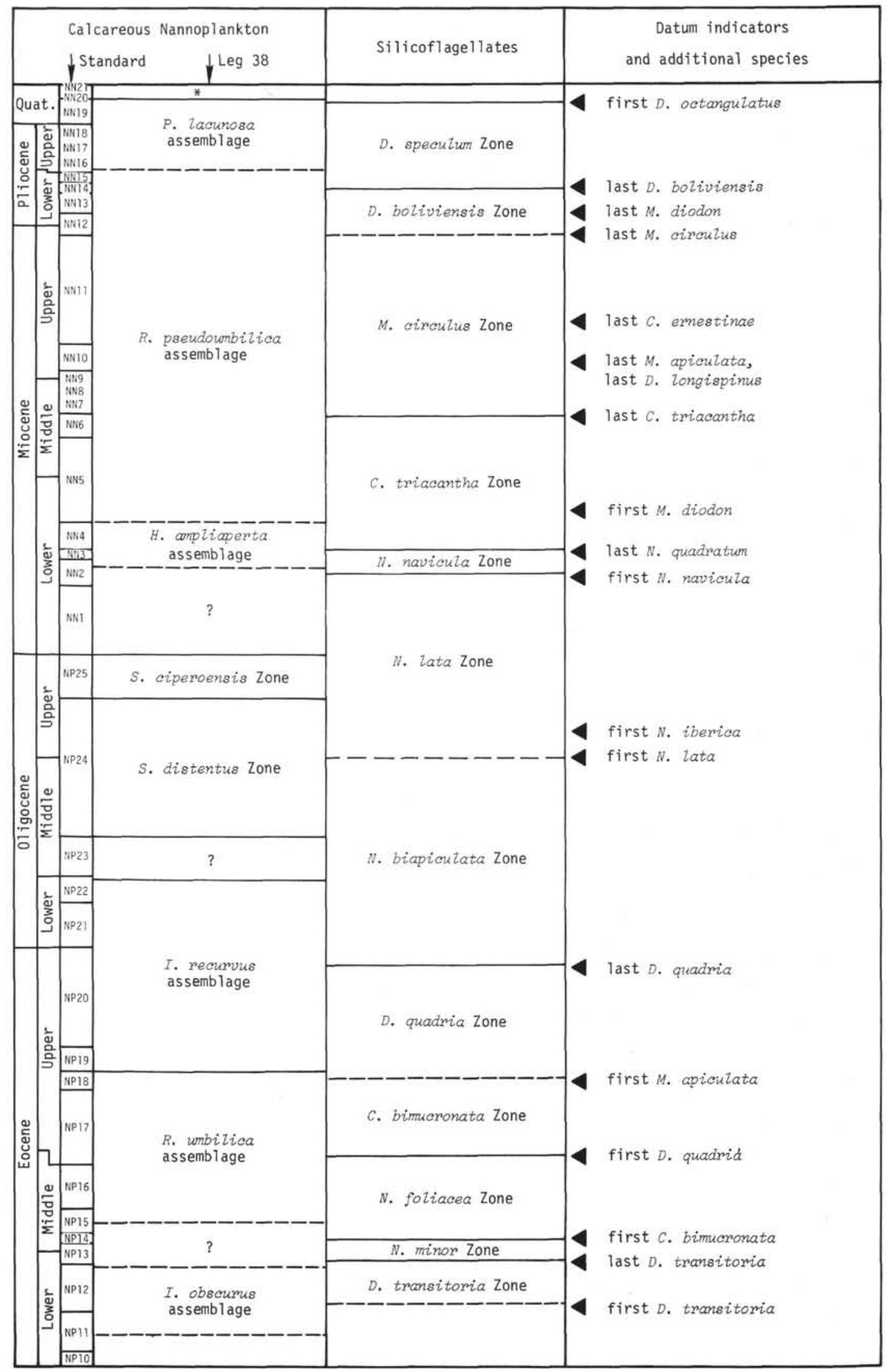

Figure 3. Silicoflagellate zonation used on Leg 38 and correlation to the standard nannoplankton zonation (Martini, 1971), and Leg 38 nannoplankton zonation. 
appear in sufficient numbers in Core $5(56.5-66.0 \mathrm{~m})$ and can be attributed to the Distephanus speculum Zone.

The combined lower Miocene Zones NN 3/NN 4 are present in Cores 24 and 25 (341.5-378.5 m) from Site 348. The overlying Cores 19 to 23 are barren of nannoplankton and silicoflagellates. Core 18 (256.0-265.0 $\mathrm{m}$ ) is attributed to the Mesocena circulus Zone on basis of the rare occurrence of Mesocena circulus in Sample 18 , CC. However, the common occurrence of this particular species is in Core 14, some 66 meters above Sample 18, CC. Since Corbisema triacantha is rather rare near its upper limit, part of the interval from Cores 15 to 18 may belong to the Corbisema triacantha Zone.

Nannoplankton Zone NP 24 is present at Site 338, Sections 19-2 to 26-1 (187.5-248.0 m). Silicoflagellates found in these cores belong to the Naviculopsis lata Zone (Core 18 and 19), and Naviculopsis biapiculata Zone (Cores 19 to 24). Cores 25 and 26, Section 1 are barren of silicoflagellates. In Core 26, Section 2, silicoflagellates of the upper Eocene Dictyocha quadria Zone are present, indicating a hiatus between Section 26-1 and 26-2, which includes the lower Oligocene and uppermost Eocene.

The lowest silicoflagellate assemblage at Site 338 can be attributed to the Corbisema bimucronata Zone, and is present in Cores 27 to 29 , CC $(257.5-285.0 \mathrm{~m})$. Cores 30 and 31 are barren of silicoflagellates and calcareous nannoplankton. In Core $32(304.0-313.5 \mathrm{~m})$, calcareous nannoplankton of the lower Eocene nannoplankton Zone NP 12 is present. Standard nannoplankton Zone NP 12 is also present at Site 343 (Core 8, 212.0-221.5 m) and below. The first silicoflagellate assemblage occurs above in Core $6(193.0-202.5 \mathrm{~m})$ and can be attributed to the Naviculopsis minor Zone.

All these data are in accordance with the correlation concept shown in Figure 3.

\section{SITE SUMMARIES}

\section{Site 336 - Iceland-Faeroe Ridge}

Cores 1 to 8 (upper part) are barren of silicoflagellates. From Sample 8-5, 100-101 cm to Sample 122, $100-101 \mathrm{~cm}$ only few specimens of Distephanus speculum are present, together with sponge spicules and some diatoms. In Sample 9-4, 50-51 cm, rare specimens of Distephanus cf. octonarius were found. These samples $(72.0-135.0 \mathrm{~m})$ are tentatively placed in the Distephanus speculum Zone. Cores 10 to 14 lack silicoflagellates.

From Sample 15-1, 13-14 cm to Sample 16-4, 101-102 $\mathrm{cm}(168.5$ to $184.5 \mathrm{~m})$, the following assemblage was found: Corbisema triacantha, Distephanus crux, Distephanus speculum, Cannopilus hemisphaericus, Naviculopsis lata, Mesocena apiculata, and Rocella gem$m a$. This assemblage belongs to the Naviculopsis lata Zone, which includes the stratigraphic interval of the upper Oligocene and the lowermost Miocene. Samples $16-5,111-112 \mathrm{~cm}$ to $18-3,28-29 \mathrm{~cm}(184.5-202.5 \mathrm{~m})$ show a decrease in silicoflagellate species, and may represent the Naviculopsis lata Zone or Naviculopsis biapiculata Zone.
Samples $18-4,5-6 \mathrm{~cm}$ to $20-3,50-51 \mathrm{~cm}$ (203.0 to $220.5 \mathrm{~m}$ ) are barren of silicoflagellates. Only sponge spicules, some diatoms, and archaemonads were observed.

\section{Site 337 - Norway Basin}

Samples from the upper part of this hole are barren of silicoflagellates. The assemblage observed from Sample $9-4,140-141 \mathrm{~cm}$ to $11, \mathrm{CC}(81.5-104.0 \mathrm{~m})$ consists of Corbisema triacantha, Distephanus crux, Distephanus speculum, Naviculopsis biapiculata, Cannopilus hemisphaericus, Dictyocha cf. fibula, Dictyocha frenguellii, and Corbisema apiculata belonging to the Naviculopsis biapiculata Zone which includes the uppermost Eocene, lower and middle Oligocene.

\section{Site 338 - Outer Vфring Plateau}

Cores 1 to $7(0.0-76.0 \mathrm{~m})$ are barren of silicoflagellates. Sample 7, CC to 8-2, 58-59 cm (76.0-79.0 m) belong to the Mesocena circulus Zone, including the upper part of the middle Miocene and the upper Miocene. The assemblage consists of Distephanus crux, Mesocena circulus, Mesocena apiculata, Distephanus speculum, Mesocena diodon, Cannopilus hemisphaericus. Sample 8-3, 70-71 cm to Sample 11-4, 85-86 $\mathrm{cm}(79.0-106 \mathrm{~m})$ contain the assemblage of the Corbisema triacantha Zone without Mesocena circulus, but with Corbisema triacantha and Distephanus longispinus.

The Naviculopsis navicula Zone of the lower Miocene was determined from Sample 12-2, 5-6 cm to Sample $17-4,85-86 \mathrm{~cm}(117.0-167.5 \mathrm{~m})$, and is indicated by the presence of Naviculopsis navicula and Naviculopsis quadratum. Other species are: Distephanus crux, Distephanus speculum, Corbisema triacantha, Distephanus longispinus, Cannopilus hemisphaericus, Mesocena apiculata, and few specimens of Naviculopsis lata, Pseudorocella corona, and Mesocena elliptica. Distephanus crux and Dictyocha pentagona are abundant in most of the samples (Table 1).

Sample 18-1, $50-51 \mathrm{~cm}$ to Sample $19-2,10-11 \mathrm{~cm}$ (171.0-184.0 m) belong to the Naviculopsis lata Zone of the upper Oligocene/lower Miocene. The assemblage is the same described from the Naviculopsis navicula Zone without Naviculopsis navicula. Naviculopsis lata becomes more frequent, and Naviculopsis biapiculata was observed in this zone.

From Sample 19-2, 85-86 cm to Sample 24-4, 37-38 $\mathrm{cm}(185.0-234.0 \mathrm{~m})$ the Naviculopsis biapiculata Zone was determined with following species: Distephanus speculum, Distephanus crux, Cannopilus hemisphaericus, Mesocena apiculata, Dictyocha hexacantha. Silicoflagellates are less common in the nannofossil ooze, and disappear in Sample 24-4, $144-145 \mathrm{~cm}$ to Sample 26-1, 67-68 cm (234.0-248.0 m). Between Core 26 , Section 1 and Core 26, Section 2, a hiatus is indicated by the presence of a silicoflagellate assemblage of the upper Eocene (Dictyocha quadria Zone) in the latter and calcareous nannoplankton of Zone NP 24 (middle Oligocene) in Core 26, Section 1.

The Dictyocha quadria Zone was determined from Sample 26-2, 109-110 cm to Sample 26-5, 30-31 cm (249.0-254.5 m), with Naviculopsis ponticula, Dictyocha 
quadria, Mesocena apiculata, Dictyocha hexacantha, Distephanus speculum, Dictyocha frenguellii. The assemblage below, which lacks Mesocena apiculata, can be attributed to the upper Eocene Corbisema bimucronata Zone. The sediments below Core 29 are barren of silicoflagellates.

\section{Site 339 - Inner Vøring Plateau}

Siliceous ooze is intercalated in Quaternary sediments probably due to slumping. From Sample 6-3, 39$40 \mathrm{~cm}$ to Sample 8-1, 20-21 cm (51.0-67.0 m) mixed assemblages from the upper Eocene to lower Oligocene were noted. In Sample 7-3, 61-62 cm, a displaced assemblage of the Mesocena circulus Zone was found (Table 2). These assemblages were probably redeposited during the time of deposition of the Distephanus speculum Zone elsewhere. In Sample 9, CC to Sample 12, CC (84.0-108.0 m) Corbisema triacantha, Corbisema apiculata, Corbisema flexuosa, Dictyocha challengeri, Dictyocha hexacantha, Mesocena apiculata, Naviculopsis constricta, and probably a new species of Micromarsupium are present, indicating the late Eocene to middle Oligocene Naviculopsis biapiculata Zone.

\section{Site 340 - Inner Vøring Plateau}

Silicoflagellates are present from Core 1, Section 4 to Sample 11, CC (6.0-106.5 m). The assemblages indicate a middle to late Eocene age. The sequence is mixed probably due to diapiric activities in this area. It is possible to recognize three units $(\mathrm{A}, \mathrm{B}$, and $\mathrm{C})$ with typical assemblages (Table 3). Unit B (Core 1 to Core 3, Section 1 and Core 6 to Core 8 Section 5) and C (Sample 8, CC to Sample 11, CC) belong to the Corbisema bimucronata Zone with the following species present: Corbisema triacantha, Distephanus crux, Naviculopsis ponticula, Mesocena apiculata, Dictyocha quadria, Dictyocha spinosa, Corbisema bimucronata, Naviculopsis foliacea, and Corbisema flexuosa. In the lower part of Unit B, a mass occurrence of the diatom Triceratium barbadense (diatom 340 in Table 3) was noted. Unit C (Sample 8, CC to Sample 11, CC) probably represents the youngest part of this zone.

Unit A (Sample 3, CC to Sample 5, CC), intercalated in repeated parts of Unit B, probably belongs to the Naviculopsis foliacea Zone of the middle Eocene with Mesocena oamaruensis, Naviculopsis ponticula, Distephanus speculum, and Corbisema spinosa. Dictyocha quadria is missing.

\section{Site 341 - Inner V $\phi$ ring Plateau}

Silicoflagellates observed in the siliceous ooze which is intercalated in Quaternary sediments of Sample 4, CC to Sample 7, CC (38.0-66.5 m) indicate a middle Miocene age, and represent displaced material with common Distephanus crux, Distephanus speculum, Cannopilus hemisphaericus, and rare Mesocena apiculata and Distephanus longispinus. Cores 8 to 25 (66.5-342.0 m) are barren of silicoflagellates. In Core 25, only sponge spicules, some diatoms, and archaeomonads were found. Silicoflagellate assemblage of Sample 25, CC to Sample 34, CC (342.0-456.0 m) consists of the following species: Distephanus crux, Mesocena diodon, Distephanus speculum, Cannopilus hemisphaericus,
Mesocena circulus, Mesocena elliptica, Mesocena apiculata, and Dictyocha cf. fibula indicating a middle to late Miocene age (Mesocena circulus Zone). Archaeomonads are common in some samples.

\section{Site 342 - Outer Vøring Plateau}

Silicoflagellates are not present in Cores 1 and 2, but are common in Sample 3-1, 95-96 cm to Core 6, CC (85.0-151.5 m). The assemblage of Sample 3-1, 95-96 $\mathrm{cm}$ to Sample 3-4, $45-46 \mathrm{~cm}$ consists of Distephanus crux, Mesocena diodon, and Distephanus speculum. From Sample 3-4, 145-146 cm to Sample 5-6, 115-116 $\mathrm{cm}$, Distephanus longispinus, Cannopilus hemisphaericus, and Mesocena apiculata are present, while Mesocena diodon is missing. This interval belongs to the Corbisema triacantha Zone of the lower Miocene to middle Miocene.

The sequence from Sample 6-2, 30-31 cm to Sample 6-4, 65-66 $\mathrm{cm}$ belongs to the Naviculopsis navicula Zone of the lower Miocene, as indicated by the presence of rare Naviculopsis navicula and common Naviculopsis lata. In the Sample 6-4, 115-116 cm and Sample 6, CC, Naviculopsis navicula was not observed. This part seems to belong to the Naviculopsis lata Zone of upper Oligocene to lower Miocene.

\section{Site 343 - Lofoten Basin}

Displaced silicoflagellates were found in Sample 3-5, $84-85 \mathrm{~cm}$ in a siliceous ooze, which is intercalated into Quaternary sediments. The assemblage consists of Corbisema triacantha, Dictyocha frenguellii, Dictyocha $\mathrm{cf}$. fibula, and Corbisema apiculata. From Sample 5-3, 100$101 \mathrm{~cm}$ to Sample 6-1, 128-129 cm (149.5-194.0 m) an assemblage (Table 4) consisting of Distephanus speculum, Corbisema spinosa, Naviculopsis foliacea, Dictyocha rotundata, Dictyocha cf. fibula, Corbisema apiculata, Dictyocha deflandrei, Dictyocha frenguellii, and Naviculopsis cf. minor is present, probably belonging to the middle Eocene Naviculopsis minor Zone. This assemblage is similar to that of part of the so-called "Unter Eozän 4" of the micropaleontological subdivision of the Paleogene in northwestern Germany (Martini, 1974).

\section{Site 345 - Mohns Ridge}

First silicoflagellates were found in Sample 6-1, 123$124 \mathrm{~cm}(56.5 \mathrm{~m})$ : Mesocena apiculata, Cannopilus hemisphaericus, Distephanus speculum, Distephanus crux, Distephanus longispinus, indicating a middle Miocene age (probably Corbisema triacantha Zone). Corbisema triacantha and Naviculopsis quadratum are present in Sample 8-1, 139-140 cm $(85.5 \mathrm{~m})$, together with the same species as in Cores 6 and 7. According to Martini (1972), Naviculopsis quadratum in its typical form indicates an early Miocene age and is present in the upper part of the Naviculopsis navicula Zone.

In Core $9(112.5-122.0 \mathrm{~m})$ only very few silicoflagellates are present, such as Distephanus crux, Corbisema triacantha, Distephanus speculum, and Naviculopsis lata. They are more frequent in the upper part of Core $10(131.5-141.0 \mathrm{~m})$. The assemblage with Corbisema triacantha, Distephanus crux, Dictyocha fibula, Naviculopsis lata, Distephanus speculum, Mesocena 
TABLE 3

Silicoflagellates in Selected Samples from Site 340 Representing the Upper Eocene Interval

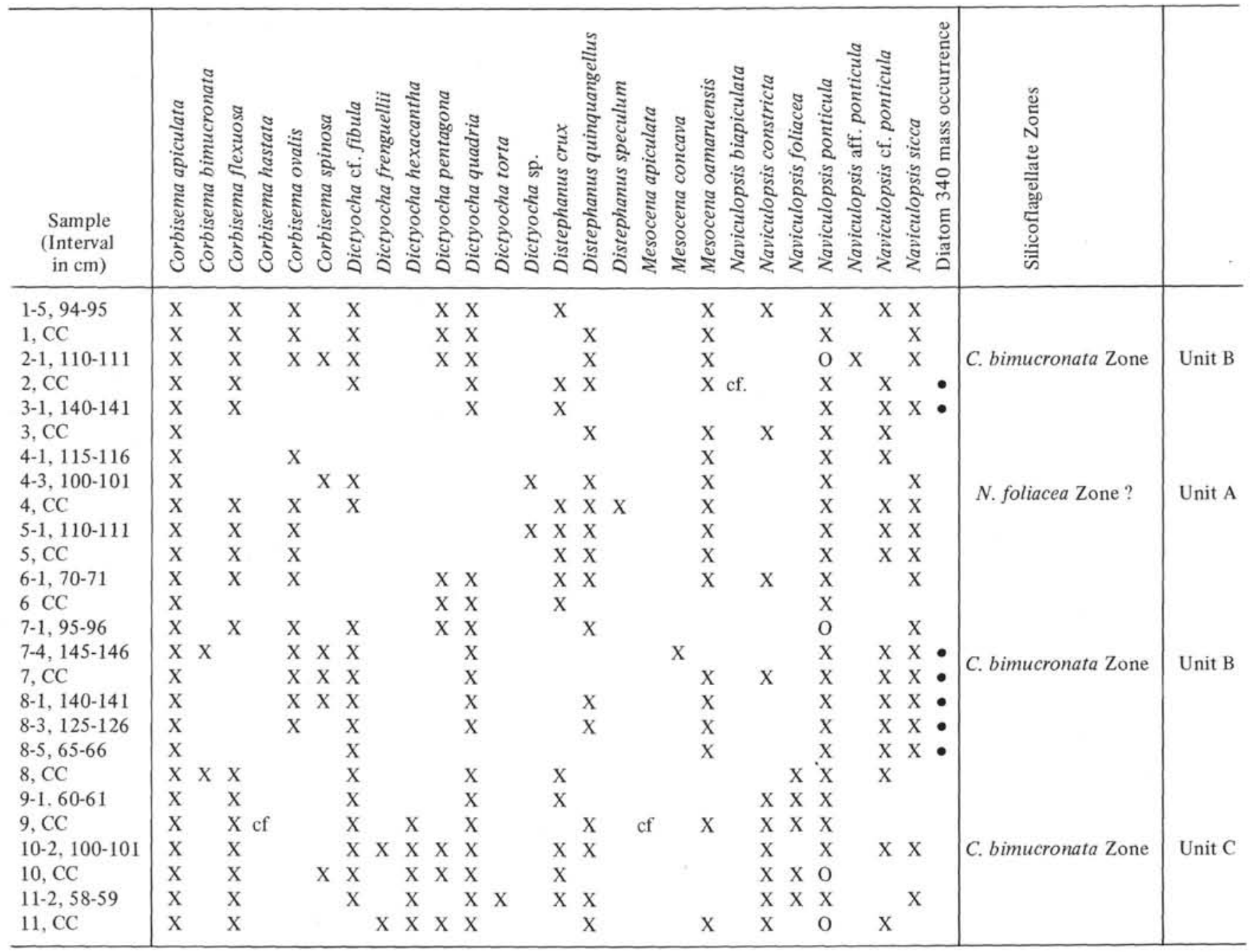

Note: $\mathrm{X}=$ rare to few, $\mathrm{O}=$ common or dominant, $\mathrm{O}=$ mass occurrence of diatom $340(=$ Triceratium barbadense $)$. Note that the succession in this particular hole is not in order due to diapiric processes. Unit A probably is the oldest and Unit C is the youngest part.

TABLE 4

Silicoflagellates in Selected Samples from Site 343

Representing the Early Middle Eocene Interval

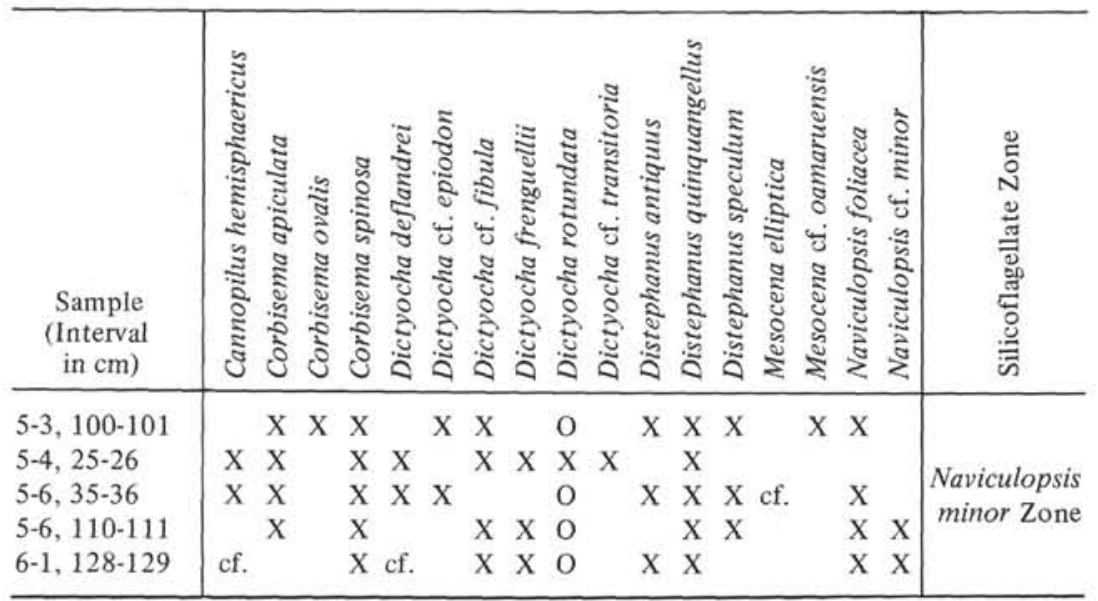

Note: $\mathrm{X}=$ rare to few $\mathrm{O}=$ common or dominant. 
apiculata probably belongs to the late Oligocene to early Miocene Naviculopsis lata Zone. In the lower part of Core 10, silicoflagellates are only sporadically present. Below Core 10, they are missing. Archaeomonads are common in some samples.

\section{Site 346 - Jan-Mayen Ridge}

Cores 1 to 3 and upper part of Core 4 are barren of silicoflagellates. They are rare from Sample 4-5, 40-41 $\mathrm{cm}$ to Sample 11-4, 75-76 cm (33.5-98.0 m), below only sponge spicules and archaeomonads were found. Few silicoflagellates were observed from Sample 4-5, 40-41 $\mathrm{cm}$ to Sample 5-2, 131-132 cm. They become more common from Sample 5-3, 50-51 cm to Sample 6-2, 84-86 $\mathrm{cm}$. Below, a decrease in abundancy down to Sample $12, \mathrm{CC}$ is noted. The assemblage consists of Corbisema triacantha, Distephanus crux, Mesocena apiculata, Cannopilus hemisphaericus, Dictyocha cf. fibula, and Distephanus speculum indicating the middle Miocene Corbisema triacantha Zone. Archaeomonads are generally abundant in all samples. Below Core 12, CC, sediments are barren of silicoflagellates.

\section{Site 348 - Iceland Plateau}

The first silicoflagellates are present in Core 5 (56.5$66.0 \mathrm{~m}$ ) with Distephanus octonarius and several varieties of Distephanus speculum, indicating cold water temperatures. The assemblage belongs to the upper Pliocene-Pleistocene Distephanus speculum Zone. The Distephanus boliviensis Zone was noted from Sample 6$1,105-106 \mathrm{~cm}$ to Sample 10, CC (66.0-142.0 m), and represents the uppermost Miocene to lower Pliocene. Species found include: Distephanus boliviensis, Distephanus speculum, Distephanus quinquangellus, and Mesocena diodon, which has its last occurrence within this zone (Table 5).

The Mesocena circulus Zone is determined from Sample 11-1, 20-21 cm to Sample 18, CC (151.5-265.0 $\mathrm{m})$. The assemblage consists of Mesocena circulus, Mesocena diodon, Mesocena apiculata, Distephanus crux, Distephanus speculum, Mesocena elliptica, Cannopilus hemisphaericus, and Dictyocha fibula. The lower part of this interval lacks Mesocena circulus, except for one specimen in Sample 18, CC. As Corbisema triacantha is rather rare near its upper limit, part of the interval from Cores 15 to 18 may belong to the Corbisema triacantha Zone. Also, a strong increase in aberrant forms was noted in Cores 15 and 16 (A in Table 5), indicating abnormal conditions. Noteworthy is the mass occurrence of "diatom 348" (=Stephanogonia horridus) in the lower part of Core 16.

\section{Site 350 - Jan-Mayen Ridge}

Silicoflagellates were observed only in Core 3, CC $(65.0 \mathrm{~m})$ indicating a probable middle Miocene age. The assemblage consists of few specimens of Distephanus crux, Distephanus speculum, and Dictyocha cf. fibula.

\section{Hole 352A - Iceland-Faeroe Ridge}

Only few silicoflagellates were found in Sample 352A-3-1, 65-66 cm. The assemblage consists of Dic- tyocha speculum, and Cannopilus hemisphaericus. Nannoplankton above and below this sample indicates an Oligocene age. The sample is rich in volcanic glass.

\section{SKELETAL CHARACTERISTICS OF SILICOFLAGELLATES}

\section{Spherical-like Protuberances in Silicoflagellates}

Deflandre (1933) reported two cases of "sphères énigmatiques" in a study of skeletal abnormalities found in fossil silicoflagellates. One "sphère énigmatique" was present in the central bar of a "Dictyocha fibula Ehr. var brevispina Lemm." from Sendai, Japan. According to the illustrations (Deflandre 1933, pl. 9 fig. 1,2 ; pl. 10 fig. 1) and the description given, there is a globular thickening at the connecting point of the central bar with the two supporting bars. The second specimen with "sphères énigmatiques" probably represents an abnormal specimen of "? Distephanus speculum (Ehr.) Haeck." from Redondo, in which globular thickenings are again present at the connecting points, in this case between the supporting bars and the basal ring (Deflandre 1933, pl. 1 fig. 3-5; pl. 2 fig. 2).

Mesocena nodulifera Tsumura and Mesocena nodulifera var. triangula Tsumura, described in Tsumura (1963), and, showing globular thickenings on the basal ring, may also represent morbid specimens of already described species, in this case most likely Mesocena diodon Ehrenberg and Mesocena oamaruensis (Schulz). Mandra (1969) described several specimens of silicoflagellates found during the study of Vema cruise 17 (South Atlantic Ocean, lat $51^{\circ} 08.5^{\prime} \mathrm{S}$, long $54^{\circ} 22^{\prime} \mathrm{W}$ ) sediments. They had spherical protuberances at each of the four corners of the basal ring. As these structures seem to be unknown in any described silicoflagellate genus, Mandra erected the new genus Hannaites, and named the forms in Eocene sediments Hannaites quadria. During Leg 29, this species was recovered in late Eocene sediments at Sites 281 and 283 in the Tasman Sea (Perch-Nielsen, 1975; Bukry, 1975b).

In the late Eocene silicoflagellate assemblage at Site 340 (Leg 38, Inner V $\phi$ ring Plateau), aside from some broken corners with spheres, a complete specimen of Mesocena apiculata (Schulz) was found (Plate 10, Figure 5). This had spherical-like protuberances at each of the three corners of the basal ring, which are identical with those found in Hannaites quadria. The spherical protuberances in both species occupy corner positions in all specimens found so far. The surface of the spheres are covered by numerous bosses, which was noted by Mandra (1969), and are illustrated for the present species on Plate 10, Figures $3 \mathrm{~b}, \mathrm{c}$ (this paper). Unfortunately, these forms are relatively rare, and, up to now, were not investigated with the scanning electron microscope. However, it is speculated that the surface structures at the spheres are enlarged silicoflagellate fine structure of knobs, with connecting ridges and depressions in between.

Hannaites quadria is reported from the late Eocene from the South Atlantic and from the Tasman Sea. The same stratigraphic interval was recovered during Leg 7 in the equatorial Pacific (Hole 65/1), and during Leg 38 
TABLE 5

Silicoflagellates in Selected Samples from Site 348 Representing the Middle Miocene to Early "Glacial" Interval

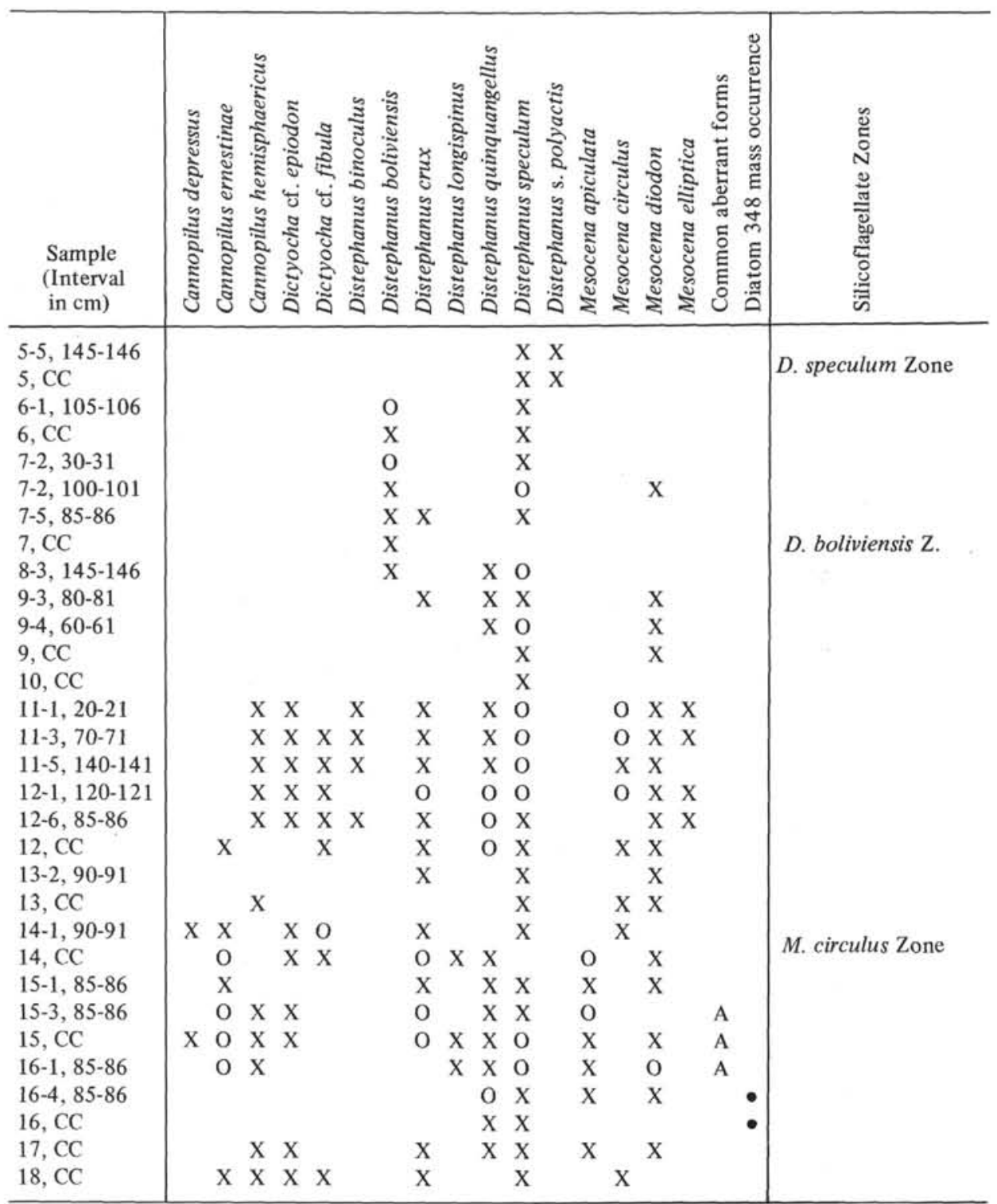

Note: $\mathrm{X}=$ rare to few, $\mathrm{O}=$ common or dominant, $\bullet=$ mass occurrence of diatom 348 ( $=$ Stephan . ogonia horridus) $\mathrm{A}=$ common occurrence of aberrant silicoflagellate specimens.

(Sites 338 and 340). However, Hannaites quadria with the typical spherical corners was not found. In the Norwegian-Greenland Sea (Sites 338 and 340), specimens identical with Hannaites, except in the corner protuberances were found in fair numbers in the interval in question (Plate 2, Figure 4; Plate 10, Figure 1). The corners of the Leg 38 specimens are rounded, whereas specimens encountered in Hole $65 / 1$ in the equatorial Pacific show somewhat flattened corners, but without spines (Plate 8, Figure 15).

These occurrences, and the Mesocena specimens with spherical protuberances (Plate 10, Figures 3-5), lead to the conclusion that this peculiar structure cannot be used for generic differentiation, and that Hannaites Mandra is a synonym of Dictyocha Ehrenberg. The occurrence of Dictyocha quadria (Mandra) nov. comb. with spherical protuberances at the corners and obviously restricted to the southern hemisphere are too rare and incompletely known to give speculation on the global development of this species. However, they certainly represent an aberrant and morbid development as Deflandre (1933) suggested and described for the aberrant specimens of "Dictyocha fibula var. brevispina" and "?Distephanus speculum."

\section{Silicoflagellate Surface Ornamentation}

Surface ornamentation of Neogene and Quaternary silicoflagellates were described by several authors (Deflandre, 1950; Jerković, 1969; Bachmann and Keck, 1969 ) as being a network of crests and depressions in most species investigated. A few specimens of the 
aberrant genus Deflandryocha were reported to lack surface ornamentation (Jerković, 1969), whereas specimens of Distephanus speculum seem to have only knots on the surface of the skeleton (Wornhardt, 1971).

Martini (in press) reported that Neogene and Quaternary silicoflagellates from the equatorial Pacific, in most cases, exhibit only small knots on an otherwise smooth surface, and that assemblages from California show better developed surface ornamentation. This probably indicates a dependence for the presence of surface structures on temperature, the presence of calcareous ingredients in the bottom sediment, and solution. Bachmann and Keck (1969) and Jerković (1969), on the other hand, related the development of surface ornamentation to the life span of silicoflagellates, inasmuch as well developed surface ornamentation is present only in the adult stage.

Silicoflagellates, found in sediments recovered in the Norwegian-Greenland Sea during Leg 38, can be divided into several groups with regard to their surface ornamentation, and are described below. Details of skeletons of several species are illustrated on Plates 5 and 6 .

The first group is characterized by a system of long crests with rare ridge-like knots approximately $90^{\circ}$ to the axis of the long crest. These were described in Mesocena diodon (Plate 6, Figure 7) and Mesocena elliptica (Plate 6, Figure 6). Closely related is the second group including Corbisema triacantha (Plate 1, Figures 8, 9), Corbisema apiculata (Plate 5, Figures 4, 5), and Naviculopsis ponticula (Plate 6, Figure 8), which show a similar ornamentation on the radial and supporting spines. However, in this group, most of the basal ring and apical structure is covered by a net-like ornamentation of short crests and depressions. Also belonging to this group are forms in which the entire distal side is covered by net-like crests (some long and some short) and peaks like Dictyocha pentagona (Plate 5, Figure 11), Dictyocha cf. epiodon (Plate 5, Figure 7), and Dictyocha cf. fibula (Plate 5, Figure 8).

Net-like ornamentation, in which the crests are of almost equal length on the basal ring, are found in the fourth group which includes Mesocena apiculata (Plate 6, Figure 5), as well as Dictyocha challengeri (Plate 1, Figure 10) and Dictyocha quadria (Plate 1, Figure 9) with the same ornamentation on the basal ring, but with faint ornamentation of short crests and peaks or without on the apical structure.

A combination of the morphologic feature of groups 1 to 3 is present in another group including Distephanus speculum (Plate 6, Figures 1a-c) and Cannopilus ernestinae (Plate 6, Figures 2-4). The basal ring is covered by long crests (Plate 6, Figures 1a, 2), with a few knots on crossing points at the basal part (Plate 6, Figures $1 b, 2)$ of the apical ring or structure. On the apical structure, knots and connecting ridges are most common on the higher parts (Plate 6, Figures 1c, 4), but apical spines seem to have a reduced number of knots (Plate 6, Figure 4). The last group is characterized by knots, which concentrate on the apical bar or apical structure, but are present also, to a lesser extent, on the basal ring. Distephanus boliviensis (Plate 5, Figure 12), and Naviculopsis lata (Plate 6, Figures 9, 10) belong to this group.
An extremely coarse surface ornamentation on silicoflagellate skeletons was noted in the late Eocene Corbisema bimucronata Zone of Hole 340, and in the early to middle Oligocene Naviculopsis biapiculata Zone of Hole 339, both from the Inner V $\phi$ ring Plateau. At Site 339, the following species are involved: Corbisema apiculata, Dictyocha cf. fibula, Dictyocha quadria, Dictyocha pentagona, Mesocena oamaruensis, Naviculopsis biapiculata, and at Site 340, Cannopilus hemisphaericus, Corbisema triacantha, Dictyocha hexacantha, Dictyocha challengeri, Mesocena apiculata, and Mesocena schulzii (Plates 1, 5, and 6).

A very peculiar surface ornamentation was noted in a specimen of Corbisema sp. (Plate 1, Figure 11) in Sample 339-7, CC (Distephanus speculum Zone), which may be reworked from older strata. The three apical bars form a plate (Plate 5, Figure 6), which shows a thickening along the rim of the otherwise smooth apical plate, with faint ridges pointing towards the center. The presence of well-developed surface ornamentation in almost all specimens found during electron-microscope studies of Leg 38 material, indicate a relation to temperature, and possibly solution. Some lower latitude species were reported (by some authors), to lack a well-developed surface ornamentation, or to exhibit only a faint one. However, a detailed study of some selected species on a more global scale is necessary to get a solid basis for the present theories.

\section{SYSTEMATIC PALEONTOLOGY}

In the description of species encountered during Leg 38 no attempt is made to give full references to all synonyma, but reference to the first description of a species and reference to a more recent description and figure will be given. In a few cases, a more detailed reference list is presented, where in recent times different names have been used for the same taxa.

The present authors are not satisfied with the generic differentiation, especially between Corbisema, Dictyocha, Distephanus, and Cannopilus, as all gradiations are present between these genera and aberrant forms of a given genus show often the characteristics of another genus. However, they remain in this paper with the differentiation used by most authors in order to avoid further confusion: Corbisema including triangular forms with apical rods or apical plate connected by rods to the basal ring; Dictyocha including four- to eight-sided forms with apical rods only; Hannaites is regarded as junior synonym of Dictyocha; Distephanus including four- and more sided forms with apical windows connected by rods to the basal ring; Cannopilus having at least a semiglobular apical structure with a number of apical windows; Mesocena including all forms consisting of an apical ring only; and Naviculopsis showing navicular outline and two radial spines in direction of the long axis.

Splitting of the mesocenid forms in a number of genera (Dumitrica, 1973; Bachmann, 1970; Locker, 1974), or extensive splitting of species in a vast number of "subspecies" (Bukry, 1975), seems unrealistic and not useful, and is not followed by the present authors.

Type specimens are deposited in the Natur-Museum und Forschungs-Institut Senckenberg, Frankfurt am Main, Germany, under catalogue numbers SM.B 12796-12799.

Class Silicoflagellatophyceae Borgert, 1891

Family DICTYOCHACEAE Lemmermann, 1901

Genus CANNOPILUS Haeckel, 1887

Cannopilus depressus (Ehrenberg)

(Plate 3, Figures 11, 12)

1854 Halicalyptra depressa Ehrenberg, Mikrobiologie, pl. 18, fig. 111.

1974 Cannopilus depressus (Ehrenberg), Locker, Eclog. Geol. Helv., v. 67, p. 639, pl. 4 , fig. 3 . 
Remarks: Included here, are globular forms which are similar or identical with those figured by Locker (1974) for the type material of Ehrenberg.

Occurrence: Rare specimens were encountered in the Mesocena circulus Zone of Site 348 (Icelandic Plateau).

\section{Cannopilus ernestinae Bachmann}

(Plate 3, Figures 8-10; Plate 6, Figures 2-4; Plate 9, Figures 6, 7)

1962 Cannopilus ernestinae Bachmann, Mikrokosmos, v. 51, p. 255, fig. 1 .

1969 Cannopilus ernestinae Bachmann, Bachmann and Keck, Mikrokosmos, v. 58, p. 204, pl. 2, fig. 2 .

Remarks: Specimens found show well-developed apical horns and are identical with those described by Bachmann and Keck (1969) from the upper Miocene of Santa Barbara, California. Specimens commonly have six radial spines, but some with five radial spines were also found.

Occurrence: In the present material ranging from the upper part of the Corbisema triacantha Zone to the middle part of the Mesocena circulus Zone at Sites 338 (V $\phi$ ring Plateau) and 348 (Icelandic Plateau).

\section{Cannopilus hemisphaericus (Ehrenberg)}

(Plate 3, Figure 7; Plate 9, Figure 5)

1844 Dictyocha hemisphaerica Ehrenberg, Ber. Akad. Wiss, Berlin, p. 266.

1974 Cannopilus hemisphaericus (Ehrenberg), Locker, Ecolog. Geol. Helv., v. 67 , p. 639 , pl. 4 , fig. $1,4,5,7,8$.

Remarks: Basal ring and radial spines are generally in one plane. Apical structure semiglobular with varying number of apical "windows."

Occurrence: Rare occurrence in the Naviculopsis minor Zone at Site 343. Consistent occurrence from the Naviculopsis biapiculata Zone to the top of the Mesocena circulus Zone. Present at Sites 336, $338,339,340,341,343,345,348$.

\section{Cannopilus sp.}

$$
\text { (Plate 8, Figure 10) }
$$

Remarks: A badly preserved single specimen possibly related to Cannopilus depressus was found in Sample 338-20-2, 30-31 cm in the upper part of the Naviculopsis biapiculata Zone ( $\mathrm{V} \phi$ ring Plateau).

\section{Genus CORBISEMA Hanna, 1928}

Corbisema apiculata (Lemmermann)

(Plate 1, Figures 1-3; Plate 5, Figures 4, 5; Plate 7, Figures 1, 2)

1901 Dictyocha triacantha apiculata Lemmermann, Ber. Dtsch. Bot. Ges., v. 19, p. 259 , pl. 10, fig. 19, 20.

1975 Corbisema apiculata (Lemmermann), Perch-Nielsen, Initial

Rept. Deep Sea Drilling Project, v. 29, p. 685, pl. 2, fig. 15, 16 ,

19; pl. 3 fig. 19, 20, 24; pl. 5, fig. I, 2.

Remarks: This species shows a great variation in size and outline, as well as in length of apical spines, and in shape of supporting spines, which may have hooks in some specimens (Plate 1, Figure 1).

Occurrence: Consistent occurrence at least from the Naviculopsis minor Zone to the top of the Mesocena circulus Zone. Present at Sites 338, 339, 340 (V $\phi$ ring Plateau), 343 (Lofoten Basin), and 348 (Icelandic Plateau).

\section{Corbisema ef. archangelskiana (Schulz) (Plate 7, Figure 5)}

1928 Dictyocha triacantha archangelskiana Schulz, Bot. Archiv, v. 21, p. 250 , fig. $33 \mathrm{a}-\mathrm{c}, 77,78$.

1975 Corbisema archangelskiana (Schulz), Perch-Nielsen, Initial Rept. Deep Sea Drilling Project, v. 29, p. 685, pl. 3, fig. 17, 22.

Remarks: A few specimens, some of which show very short radial spines and are not as angular in outline as that illustrated in Schulz (1928), were noted in the Oligocene.

Occurrence: Rare specimens in the Naviculopsis biapiculata Zone at Site 338 (V $\phi$ ring Plateau)

\section{Corbisema bimucronata Deflandre \\ (Plate 7, Figure 12)}

1950 Corbisema bimucronata Deflandre, Microscopie, v. 2, p. 191, fig. $174-177$
1974 Corbisema bimucronata Deflandre, Bukry and Foster, J. Res. U.S. Geol. Surv., v. 2, p. 307, fig. 1a.

Occurrence: Rare specimens in the Corbisema bimucronata Zone at Site 340 (V $\phi$ ring Plateau).

Corbisema flexuosa (Stradner)

(Plate 1, Figure 7; Plate 7, Figure 7)

1961 Corbisema triacantha flexusoa Stradner, Erdöl u. Kohle, v. 14 , p. 89 , pl. 1, fig. 1-8.

1975 Corbisema flexuosa (Stradner), Perch-Nielsen, Initial Rept. Deep Sea Drilling Project, v. 29, p. 685, pl. 3, fig. 10.

Remarks: Included are forms with somewhat concave sides and broad apical bars, sometimes forming a plate-like structure. Larger specimens with shorter radial spines illustrated as Corbisema $\mathrm{sp}$ (Plate 7, Figure 6) may also belong to this species.

Occurrence: In the present material, ranging from the Naviculopsis foliacea Zone(?) to the lower part of the Naviculopsis navicula Zone, found at Sites 338, 339, 340 (V $\phi$ ring Plateau).

\section{Corbisema hastata (Lemmermann)}

(Plate 1, Figure 10)

1901 Dictyocha triacantha hastata Lemmermann, Ber. Dtsch. Bot. Ges., v. 19 , p. 259 , pl. 10 , fig. 16,17 .

1975 Corbisema hastata (Lemmermann), Perch-Nielsen, Initial Rept.

Deep Sea Drilling Project, v. 29, p. 685, pl. 3, fig. 2-4, 8.

Remarks: This species, which was reported as common throughout the early Paleogene in warmer waters by Bukry and Foster (1974), is remarkably rare in the material from the Norwegian-Greenland Sea.

Occurrence: Rare in the Naviculopsis biapiculata Zone at Site 339 and a cf. specimen in Sample 340-9, CC (Corbisema bimucronata Zone) from the $\mathrm{V} \phi$ ring Plateau).

\section{Corbisema ovalis Perch-Nielsen}

(Plate 1, Figures 4, 5; Plate 7, Figures 3, 4)

In press Corbisema ovalis Perch-Nielsen, Geol. Soc. Denmark Bull. pl. 1, fig. 12, 13, pl. 2, fig. 7 .

Remarks: Specimens show rounded triangular outline with strongly concave sides, and very short radial spines pointing downwards. Some specimens have hooks on the supporting spines (Plate 7, Figure 3).

Occurrence: Rare or few in the Naviculopsis minor Zone at Site 343 (Lofoten Basin), in the Naviculopsis foliacea Zone (?) at Site 340 , and in the Corbisema bimucronata Zone at Sites 338 and 340 (V $\phi$ ring Plateau).

\section{Corbisema spinosa Deflandre}

(Plate 7, Figure 9)

1950 Corbisema spinosa Deflandre, Microscopie, v. 2, p. 193 fig. $178-182$.

1975 Corbisema spinosa Deflandre, Perch-Nielsen, Initial Rept. Deep Sea Drilling Project, v. 29 , p. 686, pl. 3, fig. 23.

Remarks: Often confused with Dictyocha hexacantha by various authors. This species shows apical spines on the apical rods, which are not in the same plane as the basal ring.

Occurrence: In the present material, rare to frequent in the Naviculopsis minor Zone to the lower part of the Naviculopsis biapiculata Zone. Found at Sites 338, 339, 340 (V $\phi$ ring Plateau), and 343 (Lofoten Basin).

\section{Corbisema triacantha (Ehrenberg)}

(Plate 1, Figures 8, 9)

1845 Dictyocha triacantha Ehrenberg, Ber. Akad. Wiss. Berlin, 1844 , p. 80 .

1974 Corbisema triacantha (Ehrenberg), Locker, Eclog. Geol. Helv., v. 67 , p. 634 , pl. 1 , fig. 10

Occurrence: Rare to frequent from the Naviculopsis biapiculato Zone to the top of the Corbisema triacantha Zone. Present at Sites 336 (Iceland-Faeroe Ridge), 337 (Norway Basin), 338, 339, 341, 342 (V $\phi r-$ ing Plateau), 345 (Mohns Ridge), and 346 (Jan-Mayen Ridge).

Corbisema sp.

(Plate 1, Figure 11)

Remarks: Rare specimens of a Corbisema species with a large flat apical plate, similar to Corbisema flexuosa, were found in the 
Distephanus speculum Zone at Site 339, and may be reworked from older strata.

\section{Genus DICTYOCHA Ehrenberg, 1840}

\section{Dictyocha ausonia Deflandre}

1950 Dictyocha ausonia Deflandre, Microscopie, v. 2, p. 195, fig. 194-202.

Remarks: Forms included are within the variation of Dictyocha ausonia published by Deflandre (1950). Specimens found were covered by diatom debris and they are not illustrated.

Occurrence: Rare specimens are present in the Naviculopsis lata Zone and Naviculopsis navicula Zone at Site 338 (V $\phi$ ring Plateau).

Dictyocha challengeri n. sp.

(Plate 2, Figure 8; Plate 5, Figure 10; Plate 8, Figure 3)

Description: Large pentagonal form with simple apical structure and short radial spines. Outline of the basal ring slightly concave at the connecting points with the apical rods. Apical structure triradiate in the central part with two bifurcating rods and one straight rod, leading to the basal ring, resulting in three larger and two smaller "windows." Surface ornamentation on the distal side of the basal ring net-like, apical structure with faint ornamentation of short crests and peaks, or without ornamentation.

Size: $110-125 \mu \mathrm{m}$.

Remarks: Distinguished from the similarly constructed Dictyocha pentagona by the large size and the concavity of the basal ring at the connecting points with the apical rods. Surface ornamentation similar to that of Dictyocha quadria.

Occurrence: Few in the late Eocene to middle Oligocene Naviculopsis biapiculata Zone at Site 339 (V $\phi$ ring Plateau).

Holotype: SM.B 12796.

Type locality: Site 339 (V $\phi$ ring Plateau) Core 12 , Section 3.

\section{Dictyocha deflandrei Frenguelli}

(Plate 7, Figure 11)

1940 Dictyocha deflandrei Frenguelli, Rev. Mus. La Plata, ser. 2, v. 2 , p. 65 , fig. $14 a-d$

1975a Dictyocha deflandrei Frenguelli, Bukry, Initial Rept. Deep Sea Drilling Project, v. 28, p. 711, pl. 1, fig. 7-10.

Occurrence: Rare specimens have been found in the Naviculopsis minor Zone at Site 343 (Lofoten Basin), and in the Dictyocha quadria Zone at Site 338 (V $\phi$ ring Plateau).

Dictyocha cf. epiodon Ehrenberg

(Plate 5, Figure 7; Plate 8, Figure 1)

1845 Dictyocha epiodon Ehrenberg, Ber. Akad. Wiss. Berlin 1844, p. 79 .

1974 Dictyocha epiodon Ehrenberg, Locker, Eclog. Geol. Helv., v. 67, p. 634 , pl. 1, fig. $1,4$.

Remarks: Although the type material of the Ehrenberg collection was recently revised by Locker (1974), the confusion within the "Dictyocha fibula" group and "Dictyocha epiodon" group is not solved. A detailed study and application of statistical methods seems necessary which is beyond the scope of the present paper. All forms of more or less quadrate outline with four radial spines, and vertical central bar supported by four apical rods are included here. A differentiation in subspecies or varieties was not attempted.

Occurrence: Rare in Naviculopsis minor Zone at Site 343 (Lofoten Basin), in the Corbisema bimucronata Zone, the Naviculopsis navicula Zone, and Mesocena circulus Zone at Site 338 (V $\phi$ ring Plateau). Few in the Mesocena circulus Zone at Site 348 (Icelandic Plateau) (compare Tables 1 to 5). Also occasionally present at Sites 339 and 342 (V $\phi$ ring Plateau).

\section{Dictyocha cf. fibula Ehrenberg}

(Plate 2, Figures 1-3; Plate 5, Figure 8; Plate 8, Figures 2, 4)

1838 Dictyocha fibula Ehrenberg, Abh. Akad. Wiss. Berlin 1836, p. 129.

1974 Dictyocha fibula Ehrenberg, Locker, Eclog. Geol. Helv., v. 67,

p. 635 , pl. 1, fig. $3,6,11$.

Remarks: As discussed in Dictyocha cf. epiodon, the confusion within the "Dictyocha fibula" group is not yet solved. Included in Dictyocha cf. fibula are forms of more or less quadrate basal ring with four radial spines and horizontal central bar supported by four apical rods. Size of the basal ring and length of the radial spines are rather variable. A few examples are illustrated on the plates listed. A very large variety was found in Core 27 at Site 341, and in Core 14 at Site 348 , both in the Mesocena circulus Zone (Plate 2, Figures 1, 2 and Plate 8, Figure 2).

Occurrence: Present in the Naviculopsis minor Zone at Site 343 (Lofoten Basin), and the Naviculopsis foliacea Zone (?) and Corbisema bimucronata Zone at Site 340 (V $\phi$ ring Plateau). Rare in the Corbisema bimucronata Zone, Naviculopsis lata Zone, the Naviculopsis navicula Zone and Corbisema triacantha Zone at Site 338 (V $\phi$ ring Plateau). Few to fairly common in the Mesocena circulus Zone at Site 348 (Icelandic Plateau). Also occasionally present at Site 336 (Iceland-Faeroe Ridge), 339 and 342 (V $\phi$ ring Plateau), 345 (Mohns Ridge), and 346 (Jan-Mayen Ridge).

\section{Dictyocha frenguellii Deflandre}

(Plate 2, Figure 9)

1950 Dictyocha frenguellii Deflandre, Microscopie, v. 2, p. 194, fig. 188-193.

1975 Dictyocha frenguellii Deflandre, Perch-Nielsen, Initial Rept. Deep Sea Drilling Project, v. 29, p. 686, pl. 4, fig. 14, 17; pl. 5, fig. 1 .

Remarks: The few specimens found show only short spines near the base of the apical rods supporting the basal ring. A five-sided specimen, with well-developed spines (Plate 2, Figure 9), was found in Sample 340-11, CC.

Occurrence: Present in the Naviculopsis minor Zone at Site 343 (Lofoten Basin), very rare in the Corbisema bimucronata Zone at Site 340 , and few in the Dictyocha quadria Zone at Site 338 (both V $\phi$ ring Plateau).

\section{Dictyocha hexacantha Schulz}

(Plate 2, Figure 7; Plate 7, Figure 10)

1928 Dictyocha hexacantha Schulz, Bot. Arch., v. 21, p. 255, fig. 43. 1975 Corbisema hexacantha (Schulz), Perch-Nielsen, Initial Rept. Deep Sea Drilling Project, v. 29, p. 685, pl. 3, fig. 13, 14.

Remarks: This species is characterized by a triagonal apical structure and six radial spines, three of which originate from the connecting point of the apical bars with the basal ring, and which are in the same plane as the basal ring.

Occurrence: In the present material found in the Corbisema bimucronata Zone at Site 340 and in the Naviculopsis biapiculata Zone at Site 339 (both V $\phi$ ring Plateau).

\section{Dictyocha pentagona (Schulz)}

(Plate 2, Figures 5, 6; Plate 5, Figure 11; Plate 8, Figures 5, 8, 9) 1928 Dictyocha fibula var. pentagona Schulz, Bot. Arch., v. 21, p. 255 , fig. $41 \mathrm{a}$.

1973 Dictyocha pentagona (Schulz), Bukry and Foster, Initial Rept.

Deep Sea Drilling Project, v. 16, p. 827, pl. 3, fig. 10.

Remarks: Forms included here are five- or six-sided, and show a crooked apical structure which is connected to the basal ring by five or six, respectively, bars of unequal length. They differ from Dictyocha challengeri in the smaller size and the more angular outline.

Occurrence: Present in fair number in the Corbisema bimucronata Zone and Dictyocha quadria Zone at Sites 338 and 340. More common in the Naviculopsis lata Zone and Naviculopsis navicula Zone at Site 338 (V $\phi$ ring Plateau).

Dictyocha quadria (Mandra) nov. comb.

(Plate 2, Figure 4; Plate 10, Figures 1, 2; Plate 5, Figure 9)

1969 Hannaites quadria Mandra, Occ. Pap. Calif. Acad. Sci., no. 77, p. 3, fig. 1-7.

1975 Hannaites quadria Mandra, Perch-Nielsen, Initial Rept. Deep Sea Drilling Project, v. 29, p. 688, pl. 8, fig. 9, 10, 12-14.

1975b Hannaites quadria Mandra, Bukry, Initial Rept. Deep Sea Drilling Project, v. 29, pl. 3, fig. 1.

Remarks: As discussed earlier, "Hannaites" is a synonym of Dictyocha, and Hannaites quadria should be transferred to Dictyocha quadria, including forms with rounded corners, flattened or inflated corners. Typical is the outline of the basal ring, which is more or less concave at the connecting points with the four supporting rods of the apical bar.

Occurrence: It is present in the late Eocene Corbisema bimucronata Zone and Dictyocha quadria Zone, which can be correlated with 
most of the standard nannoplankton Zone NP 17 (Discoaster saipanensis Zone), to most of Zone NP 20 (Sphenolithus pseudoradians Zone). In the present material found at Site 340, Cores 1 to 3 and 6 to 11 , and Site 338, Cores 26 to 29 (Tables 1 and 3). Also known from the equatorial Pacific (DSDP 65/1-8, CC) with flattened corners, and from the southwest Pacific Ocean (Tasman Sea, DSDP Site 281, Cores 14 to 16 and DSDP Site 283, Cores 3 to 6), and the South Atlantic Ocean (Vema 17-107), where it was reported the first time with spherical protuberances at the corners.

\section{Dictyocha rotundata Jousé \\ (Plate 7, Figure 16)}

1955 Dictyocha rotundata Jousé, Akad. Nauk. SSSR, Bot, Inst. Bot. Mater., v. 10, p. 78, fig. 2-3a.

Remarks: Very small rounded species with five or six irregular apical bars, which may be fused together like a small plate in the central part. Bars arched, counterfeiting corners on the basal ring.

Occurrence: Common in Cores 5 and 6 at Site 343 (Lofoten Basin), belonging to the Naviculopsis minor Zone.

\section{Dictyocha torta n. sp. \\ (Plate 8, Figure 7)}

Description: Four-sided forms with radial spines of more or less equal length at the corners. A pical structure strongly arched and built of four apical bars. Connecting points of bars at the basal ring not in the same direction as crossing lines of bars at the top of the apical structure, resulting in an obvious curvature of bars when viewed from top or from below.

Size: of basal ring: $20-27 \mu \mathrm{m}$, length of radial spines: 10-12 $\mu \mathrm{m}$.

Remarks: The curvature of apical bars distinguished this species from other forms with a cross-like apical structure like Dictyocha medusa and Dictyocha deflandrei, in which the central part of the apical structure is enlarged to an apical plate.

Occurrence: Few in the Corbisema bimucronata Zone (Unit C) at Site 340, and in the Dictyocha quadria Zone at Site 338, both from the V $\phi$ ring Plateau.

Holotype: SM.B 12797.

Type locality: DSDP Site 338 (V $\phi$ ring Plateau), Core 26, Section

\section{Dictyocha ef. transitoria Deflandre}

(Plate 7, Figure 14)

1932 Dictyocha transitoria Deflandre, Soc. Zool. France Bull., v. 79. p. 500 , fig. 32,33 .

Remarks: The specimen illustrated shows some similarity with Dictyocha transitoria, but the central bar in the apical structure is longer, and on one side of the basal ring a third spine, although very small, is present.

Occurrence: The only specimen was found in Sample 343-5-4, 25 . $26 \mathrm{~cm}$ (Lofoten Basin), belonging to the Naviculopsis minor Zone.

\section{Dictyocha sp.}

(Plate 7, Figures 8, 13)

Remarks: Elongated fibula-like form with four spines, of which those along the long axis are distinctly longer than those along the short axis. Apical structure built by a horizontal bar and four supporting rods.

Occurrence: Rare in Sample 340-4-3, 100-101 cm from the Naviculopsis foliacea Zone(?).

\section{Genus DISTEPHANUS Stöhr, 1880 \\ Distephanus antiquus Glezer \\ (Plate 7, Figures 17, 18)}

1964 Distephanus antiquus Glezer, Akad. Nauk. SSSR, Novosti Sistematiki Rasteniy, Otdel. Ottisk, p. 57, pl. 2, fig. 6-9.

Remarks: Five or six short-spined, rounded forms with a large apical ring connected to the basal ring by short rods. Apical ring slightly smaller than basal ring.

Occurrence: Present in Cores 5 and 6 of Site 343 (Lofoten Basin), belonging to the Naviculopsis minor Zone.

\section{Distephanus binoculus (Ehrenberg)} (Plate 9, Figure 1)

1845 Dictyocha binoculus Ehrenberg, Ber. Akad. Wiss. Berlin 1844, p. 79.
1973 Cannopilus binoculus (Ehrenberg), Bukry and Foster, Initial Rept. Deep Sea Drilling Project, v. 16, p. 825, pl. 1, fig. 1, 2.

Remarks: Although this form probably is a variety of Distephanus speculum, it seems to be restricted to the late Neogene. Specimens found have spines on the apical ring.

Occurrence: In the present material, found in the upper part of the Mesocena circulus Zone at Site 348 (Icelandic Plateau).

Distephanus boliviensis (Frenguelli)

(Plate 3, Figures 5, 6; Plate 5, Figure 12; Plate 9, Figure 3)

1940 Dictyocha boliviensis Frenguelli, Rev. Mus. La Plata, ser. 2, v. 2 , p. 44 , fig. 4 .

1975 Distephanus boliviensis jimlingii Bukry, Initial Rept. Deep Sea Drilling Project, v. 32, p. 683 , pl. 1, fig. 6,7 ; pl. 2, fig. 1 .

Remarks: Forms included here are relatively large and have an apical ring, which is subdivided to a number of small openings. The basal ring shows distinct supporting spines on its proximal side.

Occurrence: Present in Cores 6 to 8 at Site 348 (Icelandic Plateau) in the Distephanus boliviensis Zone, where it is especially common in the upper part of its occurrence.

\section{Distephanus crux (Ehrenberg)}

(Plate 2, Figures 10-12; Plate 7, Figure 15; Plate 9, Figure 2)

1841 Dictyocha crux Ehrenberg, Ber. Akad. Wiss. Berlin 1840, p. 207.

1974 Distephanus crux (Ehrenberg), Locker, Eclog. Geol. Helv., v. 67, p. 637, Taf. 3 , fig. 8,10 .

Remarks: Included here are all forms which have a more or less quadrate basal ring, four radial spines of equal length, and an apical ring supported by four rods. Since all gradients, from specimens with small apical ring to specimens with large apical ring were found, and since the size varies considerably, no subdivision into varieties or subspecies was attempted.

Occurrence: Few or rare in the Naviculopsis foliacea Zone (?) and Corbisema bimucronata Zone at Sites 338 and 340 (V $\phi$ ring Plateau), common to abundant from the Naviculopsis lata Zone to the Mesocena circulus Zone at Site 338 (V $\phi$ ring Plateau), and fairly common in the Mesocena circulus Zone, but rare in the Distephanus boliviensis Zone at Site 348 (Icelandic Plateau). Also present at Site 336 (Iceland-Faeroe Ridge), and Site 342 (V $\phi$ ring Plateau).

\section{Distephanus longispinus (Schulz)}

(Plate 8, Figure 11)

1928 Distephanus crux f. longispina Schulz, Bot. Arch, v. 21, p. 256, fig. 44.

1973 Distephanus longispinus (Schulz), Bukry and Foster, Initial Rept.

Deep Sea Drilling Project, v. 16, p. 828, pl. 4, fig. 7, 8.

Remarks: The radial spines along the long axis are distinctly longer than those along the short axis. Otherwise, this form is similar to Distephanus crux.

Occurrence: Occasionally found from the Naviculopsis lata Zone to the lower part of the Mesocena circulus Zone, but only in a few samples in fair numbers. Present at Sites 338, 342 (V $\phi$ ring Plateau), 345 (Mohns Ridge), and 348 (Icelandic Plateau).

\section{Distephanus octonarius (Ehrenberg)}

(Plate 8, Figure 13)

1845 Dictyocha octonaria Ehrenberg, Ber. Akad. Wiss. Berlin 1844, p. 201.

1970 Distephamus speculum (Ehrenberg), Ling, Am. Paleontol. Bull., v. 58 , p. 98 , pl. 19 , fig. 16-19.

1974 Distephanus speculum (Ehrenberg), Locker, Eclog. Geol. Helv., v. 67, p. 638, pl. 3 , fig. 7 .

Remarks: This species commonly occurs with eight, and rarely with seven or nine radial spines. It is considered by many authors as being a variant of Distephanus speculum. Its occurrence, however, seems to be rather restricted, and in this paper it is treated as distinct species.

Occurrence: Rare to few in Core 5 at Site 348 (Icelandic Plateau), and in Core 9 at Site 336 in the Distephanus speculum Zone (IcelandFaeroe Ridge). 


\section{Distephanus quinquangellus Bukry and Foster}

(Plate 3, Figure 1: Plate 9, Figure 4)

1901 Distephanus speculum var. pentagonus Lemmermann, Ber. Dtsch. Bot. Ges., v. 19, p. 264, pl. 11, fig. 19.

1973 Distephanus quinquangellus Bukry and Foster (nom. nov.), Initial Rept. Deep Sea Drilling Project, v. 16, p. 828, pl. 5, fig. 4 .

Remarks: Pentagonal form with supporting spines on the basal ring and radial spines of equal length. Simple apical ring connected by five rods with the basal ring.

Occurrence: In the present material, frequently found from the Naviculopsis minor Zone to the Naviculopsis biapiculata Zone. A few rare occurrences were noted in the Naviculopsis lata Zone and Naviculopsis navicula Zone. Few to common in the Mesocena circulus Zone and lower part of the Distephanus boliviensis Zone. Present at Sites 336 (Iceland-Faeroe Ridge), 337 (Norway Basin), 338, 340, 341, 342 (V $\phi$ ring Plateau), 343 (Lofoten Basin), 346 (Jan-Mayen Ridge), and 348 (Icelandic Plateau).

\section{Distephanus speculum (Ehrenberg)}

(Plate 3, Figures 2-4; Plate 6, Figure 1; Plate 8, Figure 12

1840 Dictyocha speculum Ehrenberg, Abh. Akad. Wiss. Berlin 1838, p. 129.

1974 Distephanus speculum (Ehrenberg), Locker, Eclog. Geol. Helv., v. 67, p. 638, pl. 3 , fig. $1-4,11(?)$.

Remarks: Included are all forms of hexagonal outline with six radial spines of equal or various length and simple apical ring connected by six rods with the basal ring. Supporting spines on the basal ring are commonly present. Specimens from the upper Miocene/Pliocene interval at Site 348 have spines on the apical ring (Plate 8 , Figure 12). Forms with large apical ring and short radial spines are listed as Distephanus antiquus.

Occurrence: Few to common at all sites drilled in the Norwegian-Greenland Sea. This species becomes abundant in some horizons of the upper Oligocene-lower Miocene, and in the Plio/Pleistocene. However, it was not found in the Corbisema bimucronata Zone of Site 340, and in the Dictyocha quadria Zone and Naviculopsis biapiculata Zone of Site 338 , both V $\phi$ ring Plateau. For details see Tables I to 5 .

\section{Genus MESOCENA Ehrenberg, 1841}

Mesocena apiculata (Schulz)

(Plate 4, Figures 1, 2; Plate 6, Figure 5; Plate 11, Figures 2, 12)

1928 Mesocena oamaruensis apiculata Schulz, Bot Arch., v. 21, p. 240 , fig. 11.

1975b Mesocena apiculata (Schulz), Bukry, Initial Rept. Deep Sea

Drilling Project, v. 29 , p. 856 , pl. 5, fig. 6-9.

Remarks: Angular or rounded three-spined rings, probably originating from Mesocena oamaruensis and first occurring at the base of the upper Eocene Dictyocha quadria Zone. Extreme large specimens (Plate 11, Figure 12) occur in the Naviculopsis biapiculato Zone at Site 339.

Occurrence: Few to common from the base of the upper Eocene Dictyocha quadria Zone to the middle to upper Miocene Mesocena circulus Zone. Present at Sites 336 (Iceland-Faeroe Ridge), 337 (Norway Basin), 338, 339, 342 (V $\phi$ ring Plateau), 345 (Mohns Ridge), and 346 (Jan-Mayen Ridge).

\section{Mesocena circulus Ehrenber}

(Plate 4, Figures 7, 8; Plate 11, Figure 4)

1841 Dictyocha (Mesocena) circulus Ehrenberg, Ber. Akad. Wiss. Berlin 1840 , p. 208.

1973 Paradictyocha circulus (Ehrenberg), Dumitrica, Initial Rept.

Deep Sea Drilling Project, v. 21, p. 853, pl. 9, fig. 7-10.

Remarks: Circular ring with two rows of short spines, the arrangement of which is best seen in the side view of the specimens illustrated on Plate 4, Figure 8. Spines may be very short in some specimens of the population.

Occurrence: Rare to few in the lower part and common in the upper part of the Mesocena circulus Zone (middle to late Miocene) at Sites 338, 341 (V $\phi$ ring Plateau), and 348 (Icelandic Plateau).

\section{Mesocena concava Perch-Nielsen}

(Plate 11, Figure 1)

In press Mesocena concava Perch-Nielsen, Geol. Soc. Denmark Bull., pl. 1 , fig. 11 ; pl. 2 , fig. 9 .

Remarks: A single specimen of this recently described species was found in Sample 340-7-4, 145-146 $\mathrm{cm}$ ( $\mathrm{V} \phi$ ring Plateau) belonging to the Corbisema bimucronata Zone.

\section{Mesocena diodon Ehrenber}

(Plate 4, Figure 5; Plate 11, Figures 5, 7, 11; Plate 6, Figure 7)

1845 Mesocena diodon Ehrenberg, Ber. Akad. Wiss. Berlin 1844, p. 84 .

1974 Bachmannocena diodon (Ehrenberg), Locker, Eclog. Geol. Helv., v. 67, p. 636 , Taf. 2 , fig. 9 .

Remarks: This species, commonly oval in shape and with two short spines, shows a tendency to produce aberrant specimens in certain horizons, probably indicating abnormal living conditions.

Occurrence: Ranging from about the middle part of the lower Miocene Corbisema triacantha Zone into the lower Pliocene Distephanus boliviensis Zone. Present in varying numbers at Sites 338 (V $\phi$ ring Plateau) and 348 (Icelandic Plateau). Aberrant specimens are common in Sample 348-16-1, 85-86 cm (Mesocena circulus Zone).

\section{Mesocena cf. diodon Ehrenberg}

(Plate 11, Figure 6)

Remarks: Almost circular specimens with somewhat crenulate outline and two only very short spines are present together with good specimens of Mesocena diodon in Core 8 and Core 9 at Site 338 (V $\phi \mathrm{r}$ ing Plateau) in the upper part of the Corbisema triacantha Zone.

\section{Mesocena elliptica Ehrenberg}

(Plate 4, Figures 5, 6; Plate 11, Figures 8, 9; Plate 6, Figure 6)

1841 Dictyocha (Mesocena) elliptica Ehrenberg, Ber. Akad. Wiss. Berlin, 1840 , p. 208

1974 Mesocena elliptica Ehrenberg, Locker, Eclog. Geol. Helv., v. 67 , p. 634 , pl. 2 , fig. 4 .

Remarks: Quadrangular ring with four short spines. The older occurrences (Plate 11, Figure 9) compare well with the lectotype from Xante. Specimens from the Mesocena circulus Zone (Plate I1, Figure 8 ) are more rounded, and the four spines show a blunt termination (Plate 4, Figures 5, 6)

Occurrence: Rare occurrences were noted from the Naviculopsis navicula Zone to the Mesocena circulus Zone at Sites 338, 342 (V $\phi$ ring Plateau), and 348 (Icelandic Plateau).

\section{Mesocena cf. elliptica (Ehrenberg}

(Plate 11, Figure 10)

Remarks: A single specimen, showing relatively long spines on a rounded quadrangular ring with a distinct offset of the spines along the short axis was found in Sample 343-5-6, 35-36 cm (Lofoten Basin) in the Naviculopsis minor Zone.

Mesocena oamaruensis Schulz

(Plate 4, Figure 4; Plate 10, Figures 3-5)

1928 Mesocena oamaruensis Schulz, Bot. Arch., v. 21, p. 240 , fig. 10a-b.

1975 Mesocena oamaruensis Schulz, Perch-Nielsen, Initial Rept. Deep Sea Drilling Project, v. 29, p. 688, pl. 10, fig. 12, 20.

Remarks: Triangular rounded ring without spines at the corners. Aberrant specimens with spherical-like protuberances were found in the Corbisema bimucronata Zone at Site 340, and are discussed in detail in a special section of this paper.

Occurrence: Frequently noted from the Naviculopsis foliacea Zone to the top of the Corbisema bimucronata Zone at Sites 338 and 340 (V $\phi$ ring Plateau).

\section{Mesocena cf. oamaruensis Schulz}

(Plate 11, Figure 14)

1975 Mesocena oamaruensis Schulz, Perch-Nielsen, Initial Rept. Deep Sea Drilling Project, v. 29, p. 688, pl. 10, fig. 13.

Remarks: A single specimen, which is nearly circular and without spines, was found in Sample 343-5-3, 100-101 cm of the Naviculopsis minor Zone (Lofoten Basin). An identical specimen was 
illustrated by Perch-Nielsen from the late Eocene of Hole 280A to the west of Tasmania.

Mesocena schulzii n. sp.

(Plate 11, Figures 3, 13)

1928 Mesocena oamaruensis cf. quadrangula Schulz, Bot Arch., v. 21, p. 240 , fig. 13.

1975 Septamesocena cf. S. quadrangula (Schulz), Perch-Nielsen, Initial Rept. Deep Sea Drilling Project, v. 29, p. 690, pl. 10, fig. 17,18 .

Description: Quadrate ring with slightly concave sides and short spines at the four corners. Septae are commonly present, net-like surface ornamentation of crests and depressions as in Mesocena apiculata.

Size: Diameter 75 to $160 \mu \mathrm{m}$.

Remarks: The rare, but consistent, occurrence in the interval from the uppermost Eocene to the lower Miocene and its distinct shape not present in any other Miocene Mesocena species seem to justify the erection of a new species. Extremely large specimens were found in the Naviculopsis biapiculata Zone at Site 339 (V $\phi$ ring Plateau).

Occurrence: Rare specimens in Samples 339-10-2, 50-51 cm (Naviculopsis biapiculata Zone) and 338-16-5, 50-51 cm (Naviculopsis navicula Zone), both from the $\mathrm{V} \phi$ ring Plateau. Originally reported from the upper Eocene of Oamaru by Schulz (1928). Also present in the late Eocene and early Miocene of Leg 29, south of New Zealand.

Holotype: SM.B 12798.

Type locality: Sample $338-16-5,50-51 \mathrm{~cm}$ (Vфring Plateau).

Genus NAVICULOPSIS Frenguelli, 1940

\section{Naviculopsis biapiculata (Lemmermann)} (Plate 12, Figure 13)

1901 Dictyocha navicula var. biapiculata Lemmermann, Ber. Dtsch. Bot. Ges., v. 19 , p. 258 , pl. 10, fig. $14,15$.

1975 Naviculopsis biapiculata (Lemmermann), Perch-Nielsen, Initial Rept. Deep Sea Drilling Project, v. 29, p. 689, pl. 12, fig. 18-22.

Remarks: Navicular form with two long spines along the long axis and a small apical bridge. The basal ring is slightly concave at the connecting points of the apical bridge.

Occurrence: In the present material, found from the Corbisema bimucronata Zone to the lower part of the Naviculopsis navicula Zone, with common occurrences in the Naviculopsis biapiculata Zone at Sites 338, 340 (cf.) V $\phi$ ring Plateau, and 337 (Norway Basin).

\section{Naviculopsis ef. biapiculata (Lemmermann)}

(Plate 12, Figure 14)

Remarks: Included are forms which have a broader basal ring, but are otherwise identical with the nominate form. They occur in a position just prior to the first occurrence of Naviculopsis lata and may be regarded as transitional forms of Naviculopsis biapiculata to Naviculopsis lata.

Occurrence: Rare to few in the upper Naviculopsis biapiculata Zone at Site 338 (V $\phi$ ring Plateau).

\section{Naviculopsis constricta (Schulz)}

(Plate 5, Figure 1; Plate 12, Figure 8)

1928 Dictyocha navicula var. constricta Schulz, Bot. Arch., v. 21, p. 245 , fig. 21 .

1975 Naviculopsis constricta (Schulz), Perch-Nielsen, Initial Rept. Deep Sea Drilling Project, v. 29, p. 689, pl. 12, fig. 16, 17, 23.

Remarks: Navicular form with long spines, and a rather broad apical bridge. Basal ring distinctly concave at the connecting points of the apical bridge.

Occurrence: Rare or few in the Naviculopsis foliacea Zone and Corbisema bimucronata Zone at Site 340, and in the Naviculopsis biapiculata Zone at Site 339, both V $\phi$ ring Plateau.

\section{Naviculopsis foliacea Deflandre}

(Plate 12, Figure 4 )

1950 Naviculopsis foliacea Deflandre, Microscopie, v. 2, p. 204 , fig. 235-240.

1972 Naviculopsis foliacea Deflandre, Ling, Am. Paleontol. Bull., v. 62 , p. 184, pl. 30, fig. 9-11.

Remarks: Slender navicular form with a very broad, but thin apical bridge. Closely related to Naviculopsis sicca.
Occurrence: Present in the Naviculopsis minor Zone at Site 343 (Lofoten Basin), in the Corbisema bimucronata Zone at Site 340 (V $\phi \mathrm{r}$ ing Plateau), and rare cf. specimens in the Naviculopsis biapiculata Zone at Site 339 (V $\phi$ ring Plateau).

\section{Naviculopsis iberica Deflandre}

(Plate 4, Figure 10; Plate 12, Figure 17)

1950 Naviculopsis iberica Deflandre, Microscopie, v. 2, p. 202, fig. 231-234.

1971 Naviculopsis iberica Deflandre, Bachmann, Verh. Geol. Bundesanst. Wien, 1971, p. 556, pl. 1, fig. 4.

Remarks: Although considered by some authors as synonym of Naviculopsis quadratum, this species with broad, but rounded basal ring, has a different range as the typical rectangular forms of Naviculopsis quadratum, and, therefore, is listed separately (compare Table 5). It is regarded as intermediate form between Naviculopsis lata and Naviculopsis quadratum.

Occurrence: Fairly frequent in the Naviculopsis lata Zone and lower part of the Naviculopsis navicula Zone at Site 338 (V $\phi$ ring Plateau).

\section{Naviculopsis lata (Deflandre)}

(Plate 4, Figure 11; Plate 6, Figures 9, 10; Plate 12, Figure 15)

1932 Dictyocha biapiculata lata Deflandre, Soc. Géol. France Bull., v. 79 , p. 500 , fig. 30,31 .

1972 Naviculopsis lata (Deflandre), Martini, Senckenberg. Lethaea, v. 53 , p. 129 , fig. 1 .

Remarks: Short but broad navicular form with tubular apical bridge and two relatively short spines at the ends. Transitional forms to Naviculopsis biapiculata are listed separately as Naviculopsis of. biapiculata.

Occurrence: Few to common in the Naviculopsis lata Zone and lower part of the Naviculopsis navicula Zone at Sites 336 (IcelandFaeroe Ridge), 338, 342 (V $\phi$ ring Plateau), and 345 (Mohns Ridge).

\section{Naviculopsis ef. minor (Schulz)}

(Plate 12, Figure 12)

1928 Dictyocha navicula var. minor Schulz, Bot. Arch., v. 21, p. 246, fig. 22 .

1966 Naviculopsis biapiculata var. minor (Schulz), Glezer, Cryptogamic Plants USSR, v. 7, p. 274, pl. 16, fig. 6-8; pl. 17, fig. 13, 6 .

Remarks: Short navicular basal ring with arched and broad apical bridge. Specimens from the "lower Eocene" in Germany are more robust, but all are within the morphologic range as indicated by Glezer (1966).

Occurrence: In the present material, found as rare specimens in the lower part of Core 5 and upper part of Core 6 at Site 343 (Lofoten Basin), belonging in the Naviculopsis minor Zone. In northern Germany occurring in the Dictyocha transitoria Zone and Naviculopsis minor Zone of the local "lower Eocene 4," a part of which, already belongs to the middle Eocene in the international sense.

\section{Naviculopsis navicula (Ehrenberg)}

(Plate 4, Figure 9; Plate 12, Figure 16)

1840 Dictyocha navicula Ehrenberg, Abh. Akad. Wiss. Berlin 1838, p. 129.

1845 Dictyocha ponticulus Ehrenberg, Ber. Akad. Wiss. Berlin 1844, p. 267.

1972 Naviculopsis navicula (Ehrenberg), Martini, Senckenberg. Lethaea, v. 53 , p. 120 , fig. 2.

1974 Naviculopsis navicula (Ehrenberg), Locker, Eclog. Geol. Helv., v. 67, p. 635 , pl. 2 , fig. 1,2 .

Remarks: Navicular basal ring, lacking distinct spines at the ends. End of the basal ring commonly broad and flat, somewhat rectangular or rounded, with or without very small horns instead of spines. Apical bridge tubular and slightly arched.

Occurrence: Frequently found in the Naviculopsis navicula Zone at Sites 338, 342 (V $\phi$ ring Plateau) and 345 (Mohns Ridge).

\section{Naviculopsis ponticula Perch-Nieisen}

(Plate 5, Figures 2, 3; Plate 6, Figure 8; Plate 12, Figures 1, 2) In press Naviculopsis ponticula Perch-Nielsen, Geol. Soc. Denmark Bull., pl. 1, fig. 1. 
Remarks: Specimens found are identical with the description and figures by Perch-Nielsen (in press), and includes navicular forms with a tubular bridge supported by two rods on each side.

Occurrence: Few to common in the Naviculopsis foliacea Zone (?), Corbisema bimucronata Zone, and lower part of the Dictyocha quadria Zone at Sites 338 and 340 (Vфring Plateau).

\section{Naviculopsis aff. ponticula Perch-Nielsen}

(Plate 12, Figures 9-11)

Remarks: Forms have a rather short navicular basal ring, with two long spines and a tubular bridge connected to the basal ring by two rods on each side. The apical bridge is strongly arched. It differs from typical Naviculopsis ponticula by the extremely short basal ring.

Occurrence: Rare specimens in Samples 338-29-1, 113-114 cm and $340-2-1,110-111 \mathrm{~cm}$ from the V $\phi$ ring Plateau. Both samples belong to the same level above the mass occurrence of diatom " 340 " (=Triceratium barbadense), and are within the range of typical Naviculopsis ponticula.

\section{Naviculopsis ef. ponticula Perch-Nielsen}

$$
\text { (Plate 12, Figure 3) }
$$

Remarks: Specimens similar to Naviculopsis ponticula, but instead of having a tubular bridge, these specimens have a slightly arched plate connected to the basal ring by four rather broad, but thin rods. Navicular ring not as broad as in typical Naviculopsis ponticula.

Occurrence: In fair numbers together with typical Naviculopsis ponticula in the Naviculopsis foliacea Zone (?) and Corbisema bimucronata Zone at Site 340 , in some samples even more common than the typical form. Also present (rare) in a few samples of the Corbisema bimucronata Zone at Site 338 , both situated on the $\mathrm{V} \phi$ ring Plateau.

\section{Naviculopsis quadratum (Ehrenberg) \\ (Plate 4, Figure 12; Plate 12, Figure 18)}

1845 Dictyocha quadratum Ehrenberg, Ber. Akad. Wiss. Berlin 1844, p. 267.

1928 Dictyocha navicula rectangulare Schulz, Bot Arch., v. 21, p. 243 , fig. $17 \mathrm{a}, \mathrm{b}$.

1972 Naviculopsis rectangularis (Schulz), Martini, Senckenberg. Lethaea, v. 53, p. 120 , fig. 3

1974 Naviculopsis quadratum (Ehrenberg), Locker, Eclog., Geol. Helv., v. 67 , p. 635 , pl. 2 , fig. 3 .

Remarks: Typical rectangular basal ring with a short spine at each end. Apical bridge tubular and slightly arched. Not included here are rounded forms, as these have a different stratigraphic range (see Naviculopsis iberica).

Occurrence: Common to frequent in the upper part of the Naviculopsis navicula Zone at Sites 338, 342 (V $\phi$ ring Plateau) and 345 (Mohns Ridge).

\section{Naviculopsis sicca n, sp.}

(Plate 12, Figures 5-7)

Description: Elongated and extreme slender form with a long spine at each end. The navicular basal ring is incorporated in the apical bridge, which is rather thin, but covers most of the space between the two spines. Only at each end of the navicular basal ring is a small opening present. Near the base of the radial spine a short supporting spine seems to be present in some specimens (Plate 12, Figure 6).

Size: Total length $100-150 \mu \mathrm{m}$, length of navicular basal ring 65 $80 \mu \mathrm{m}$, width: $8-12 \mu \mathrm{m}$.

Remarks: Distinguished from the related Naviculopsis foliacea by the extreme slender form, and the very small openings near the ends of the basal body.

Occurrence: Present in fair numbers in the upper part of the Naviculopsis foliacea Zone (?) and in the lower part of the Corbisema bimucronata Zone at Site 340 and in Sample 29, CC at Site 338 (Corbisema bimucronata Zone) on the V $\phi$ ring Plateau.

Holotype: SM.B 12799.

Type locality: Sample 340-5-1, 110-111 cm (V $\phi$ ring Plateau).
Incertae Sedis or Diatoms

Genus PSEUDOROCELLA Deflandre, 1938

Pseudorocella corona Deflandre

(Plate 8, Figure 14)

1947 Pseudorocella corona Deflandre, Soc. Bot. France Bull., v. 93, p. 397 , fig. 4.

1975b Pseudorocella corona Deflandre, Bukry, Initial Rept. Deep Sea Drilling Project, v. 29, p. 857, pl. 7, fig. 8, 9.

Remarks: Specimens are identical with figures and description of Deflandre (1947) and compare well with illustrations by Bukry (1975b).

Occurrence: Rare specimens occur from the Naviculopsis lata Zone to the Mesocena circulus Zone at Site 338 (V $\phi$ ring Plateau).

\section{Genus ROCELLA Hanna, 1930}

\section{Rocella gemma Hanna}

1930 Rocella gemma Hanna, J. Paleontol., v. 4, p. 415, pl. 40, fig. 818.

1973 Rocella gemma Hanna, Dumitrica, Initial Rept. Deep Sea Drilling Project, v. 21, p. 855 , pl. 11, fig. 7-12.

Remarks: A fairly common occurrence of this species was noted in the late Oligocene to early Miocene Naviculopsis lata Zone at Site 336 (Iceland-Faeroe Ridge), especially in Sample 336-16-2, 11-12 cm. This species is not illustrated.

\section{REFERENCES}

Bachmann, A. and Keck, A., 1969. Die Oberflächenstruktur der Silicoflagellaten: Mikrokosmos, v. 58, p. 204-207.

Bukry, D., 1973. Coccolith and silicoflagellate stratigraphy, Deep Sea Drilling Project Leg 18, Eastern North Pacific. In Kulm, L.D., von Huene, R., et al., Initial Reports of the Deep Sea Drilling Project, Volume 18: Washington (U.S. Government Printing Office), p. 817-831.

1975a. Coccolith and silicoflagellate stratigraphy near Antarctica, Deep Sea Drilling Project, Leg 28. In Hayes, D.E., Frakes, L.A., et al., Initial Reports of the Deep Sea Drilling Project, Volume 28: Washington (U.S. Government Printing Office), p. 709-723.

1975b. Silicoflagellate and coccolith stratigraphy, Deep Sea Drilling Project, Leg 29. In Kennett, J.P., Houtz, R.E., et al., Initial Reports of the Deep Sea Drilling Project, Volume 29: Washington (U.S. Government Printing Office), p. 845-872.

Bukry, D. and Foster, J.H., 1973. Silicoflagellate and diatom stratigraphy, Leg 16, Deep Sea Drilling Project. In van Andel, T.H., Heath, G.R., et al., Initial Reports of the Deep Sea Drilling Project, Volume 16: Washington (U.S. Government Printing Office), p. 815-871.

1974. Silicoflagellate zonation of Upper Cretaceous to lower Miocene deep-sea sediment: J. Res. U.S. Geol. Surv., v. 2, p. 303-310.

Deflandre, G., 1933. Formation énigmatiques du squelette chez quelques silicoflagelles: Bull. Soc. Bot. France, v. 80, p. 809-814.

1950. Contribution à l'étude des Silicoflagellidés actuels et fossiles: Microscopie, v. 2, p. 72-108.

Dumitrica, P., 1973. Paleocene, late Oligocene and postOligocene silicoflagellates in Southwest Pacific sediments cored on DSDP Leg 21. In Burns, R.E., Andrews, J.E., et al., Initial Reports of the Deep Sea Drilling Project, Volume 21: Washington (U.S. Government Printing Office), p. 837-883.

Glezer, Z.I., 1966. Silicoflagellatophycea: Cryptogamen flora USSR (English translation, Jerusalem): v. 7, p. 1-330. 
Hanna, G.D., 1928. Silicoflagellata from Cretaceous of California: J. Paleontol., v. 1, p. 259-263.

Jerković, L., 1969. Les nouvelles recherches de la superficie du squelette des Silicoflagellidés: God. Biol. Inst. Univ. Sarajevu, v. 22, p. 129-176.

Ling, H.Y., 1970. Silicoflagellates from central north Pacific core sediments: Am. Paleontol. Bull., v. 58, p. 85-129. , 1972. Upper Cretaceous and Cenozoic silicoflagellates and Ebridians: Am. Paleontol. Bull., v. 62, p. $135-229$.

1973. Silicoflagellates and ebridians from Leg 19: In Creager, J. G., Scholl, D. W., et al., Initial Reports of the Deep Sea Drilling Project, Volume 19: Washington (U.S. Government Printing Office), p. 751-775.

Locker, S., 1974. Revision der Silicoflagellaten aus der mikrogeologischen Sammlung von L.G. Ehrenberg: Eclog. Geol. Helv., v. 67, p. 631-646.

Mandra, Y.J., 1969. A new genus of silicoflagellates from an Eocene South Atlantic deep-sea core (Protozoa: Mastigophora): Occ. Pap. Calif. Acad. Sci., no. 77, p. 1-7.

Martini, E., 1971. Standard Tertiary and Quaternary calcareous nannoplankton zonation. In Farinacci, A. (Ed.), Plankt. Conf. Second Roma 1970 Proc.: Roma, (Tecnoscienza), v. 2, p. 739-785.

1972. Silicoflagellate zones in the late Oligocene and early Miocene of Europe: Senckenberg. Lethaea, v. 53 , p. $119-122$.
1974. Silicoflagellate zones in the Eocene and early Oligocene: Senckenberg. Lethaea, v. 54, p. 527-532.

, in press. Neogene and Quaternary silicoflagellates from the central Pacific Ocean (DSDP Leg 33). In Schlanger, S., Jackson, D., et al., Initial Reports of the Deep Sea Drilling Project, Volume 33: Washington (U.S. Government Printing Office).

Perch-Nielsen, K., 1975. Late Cretaceous to Pleistocene silicoflagellates from the southern Southwest Pacific, DSDP, Leg 29. In Kennett, J.P., Houtz, R.E., et al., Initial Reports of the Deep Sea Drilling Project, Volume 29: Washington (U.S. Government Printing Office), p. 677721 .

in press. New silicoflagellates and a silicoflagellate zonation in North European Eocene diatomites: Geol. Soc. Denmark Bull.

Schulz, P., 1928. Beiträge zur Kenntnis fossiler und rezenter Silicoflagellaten: Bot. Arch., v. 21, p. 225-292.

Tsumura, K., 1963. A systematic study of silicoflagellatae. J. Yokohama Municipal Univ., C 45, no. 146, p. 1-84.

Wornhardt, W.W. Jr., 1971. Eocene, Miocene and Pliocene marine diatoms and silicoflagellates studied with the electron microscope. In Farinacci, A. (Ed.), Plankt. Conf. Second Roma 1970 Proc., Roma (Tecnoscienza), v. 2, p. $1277-1300$. 


\section{PLATE 1}

Figure 1 Corbisema apiculata (Lemmermann). Proximal side, SEM 500 $\times$;

Sample 340-7, CC;

Corbisema bimucronata Zone.

Figure 2 Corbisema apiculata (Lemmermann).

Proximal side, SEM 500X;

Sample 339-12-3, 125-126 cm;

Naviculopsis biapiculata Zone.

Figure 3 Corbisema apiculata (Lemmermann).

Proximal side, SEM 500X;

Sample 339-12-3, 125-126 cm;

Naviculopsis biapiculata Zone.

Figures 4-6 Corbisema ovalis Perch-Nielsen.

Sample 340-7, CC;

Corbisema bimucronata Zone.

4. Proximal side, SEM $525 \times$.

5. Distal side, SEM $475 \times$.

6. Distal side, SEM $525 \times$.

Figure $7 \quad$ Corbisema flexuosa (Stradner).

Distal side, SEM 500×;

Sample 340-11, CC;

Corbisema bimucronata Zone.

Figures 8,9 Corbisema triacantha (Ehrenberg).

Naviculopsis biapiculata Zone.

8. Distal side, SEM $1050 \times$;

Sample 339-10-2, 55-56 cm.

9. Proximal side, SEM $950 \times$;

Sample 339-12-3, 115-116 cm.

Figure 10 Corbisema hastata (Lemmermann).

Distal side, SEM 950X;

Sample 339-10-2, 55-56 cm;

Naviculopsis biapiculata Zone.

Figure $11 \quad$ Corbisema $\mathrm{sp}$.

Distal side, SEM 950X;

Sample 339-7, CC;

Distephanus speculum Zone (displaced material).

Figure 12 Corbisema cf. apiculata (Lemmermann). Distal side, SEM 450X;

Sample 339-7, CC;

Distephanus speculum Zone (displaced material).

\section{PLATE 2}

Figures 1, 2

Figure 3

Figure 4

Figures 5, 6

Figure 7

Figure 8

Figure 9

Figure 10

Figures 11, 12

\section{San} Sample $348-11-2,20-21 \mathrm{~cm}$;
Mesocena circulus Zone.
11. Proximal side, SEM 550X.

12. Distal side, SEM $550 \times$.

Dictyocha cf. fibula Ehrenberg. Sample 348-14-1, 90-91 cm; Mesocena circulus Zone.

1. Distal side, SEM $455 \times$.

2. Proximal side, SEM $440 \times$.

Dictyocha cf. fibula Ehrenberg. Distal side, SEM 550X;

Sample 340-7, CC;

Corbisema bimucronata Zone.

Dictyocha quadria (Mandra).

Distal side, SEM 540X;

Sample 340-11, CC;

Corbisema bimucronata Zone.

Dictyocha pentagona (Schulz).

Distal sides, SEM 550X;

Sample 340-11, CC;

Corbisema bimucronata Zone.

Dictyocha hexacantha Schulz. Distal side, SEM 1000X; Sample 339-10-2, 55-56 cm; Naviculopsis biapiculata Zone.

Dictyocha challengeri $\mathrm{n}$. sp.

Distal side, SEM $225 \times$;

Sample 339-12-3, 115-116 cm;

Naviculopsis biapiculata Zone.

Dictyocha cf. frenguellii Deflandre.

Distal side, SEM 500X;

Sample 340-11, CC;

Corbisema bimucronata Zone.

Distephanus crux (Ehrenberg).

Proximal side, SEM 500×;

Sample 340-11, CC;

Corbisema bimucronata Zone.

Distephanus crux (Ehrenberg).

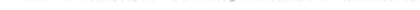

(see page 878 ) 
PLATE 1
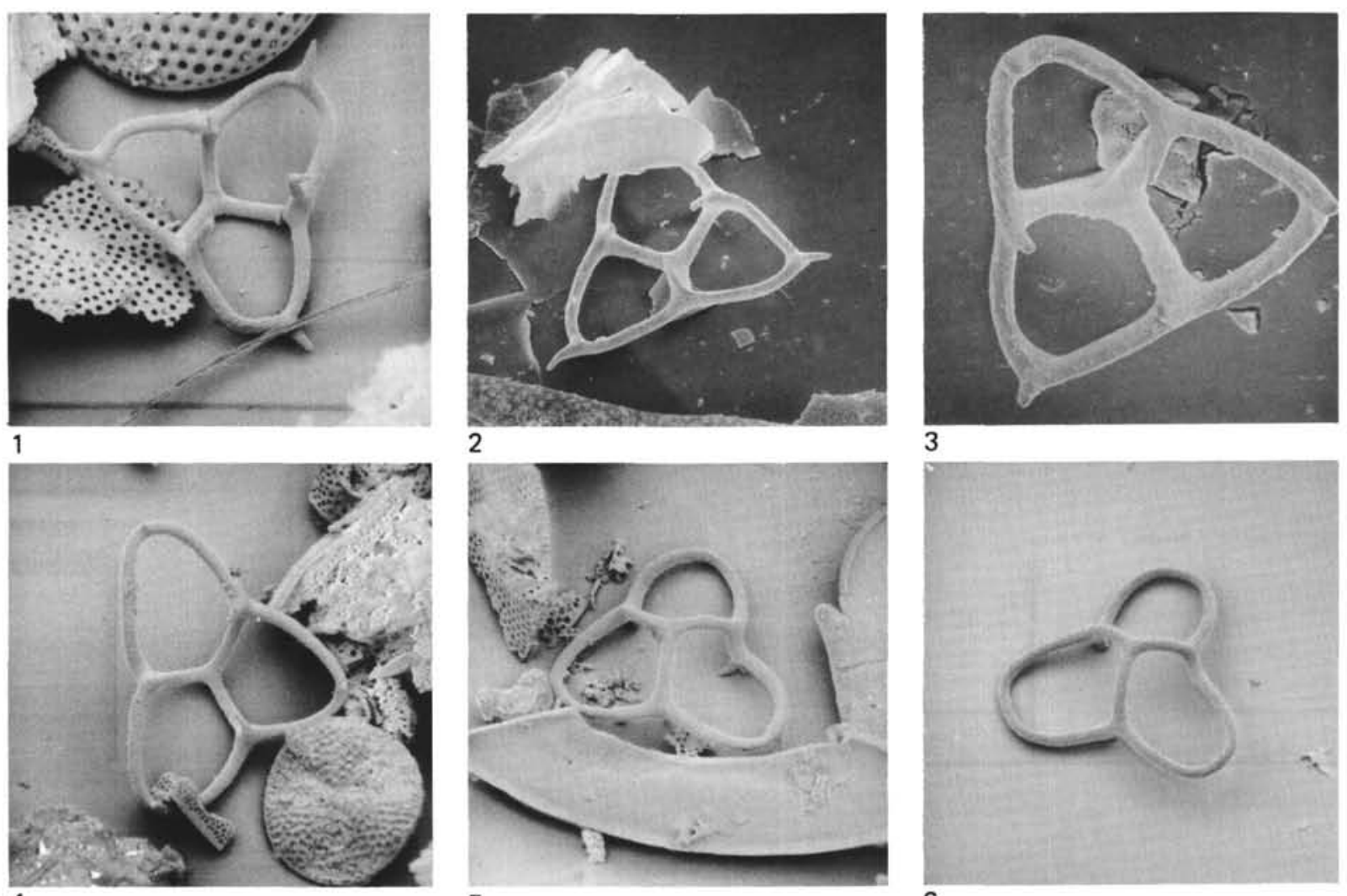

2
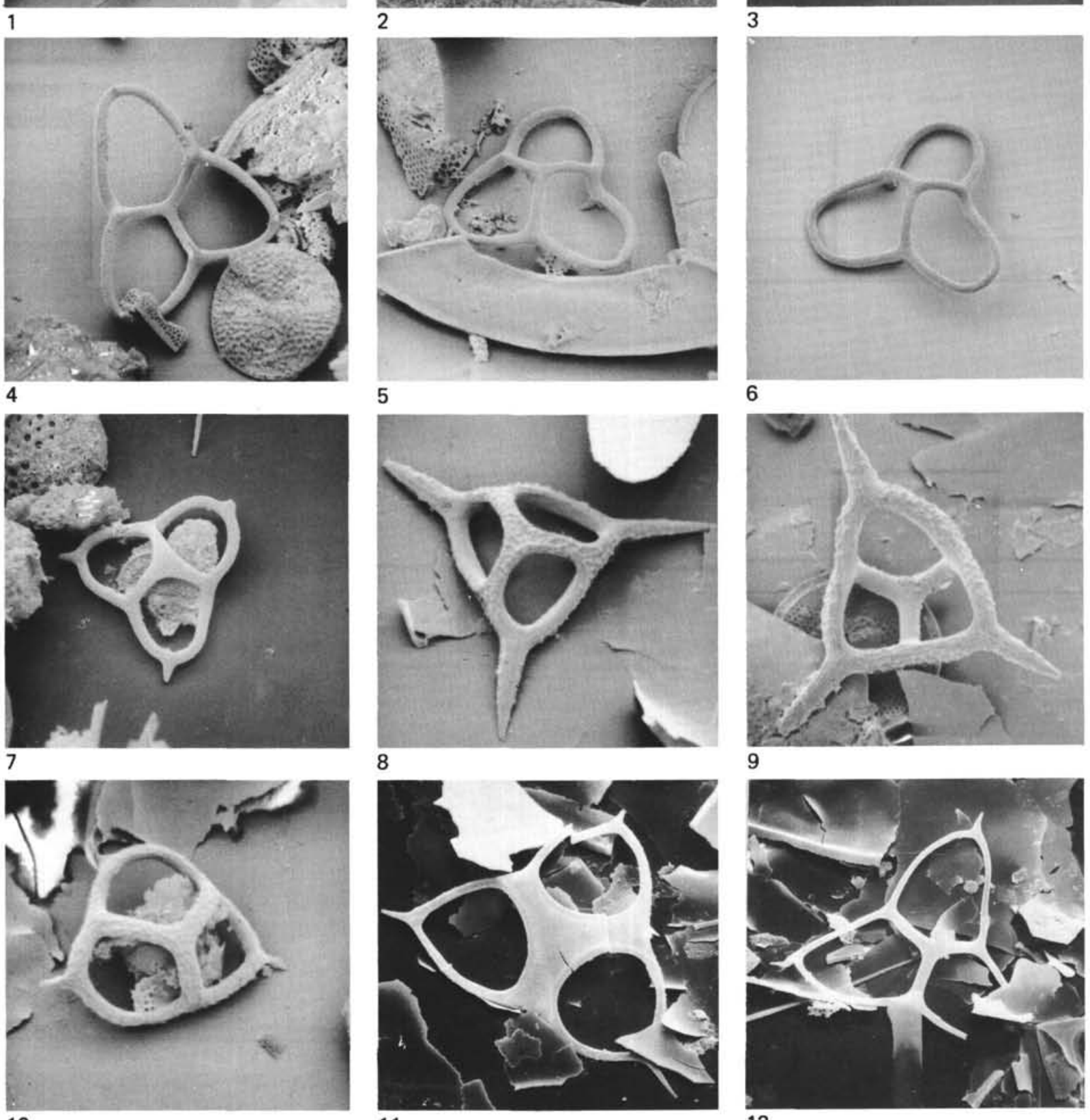
PLATE 2
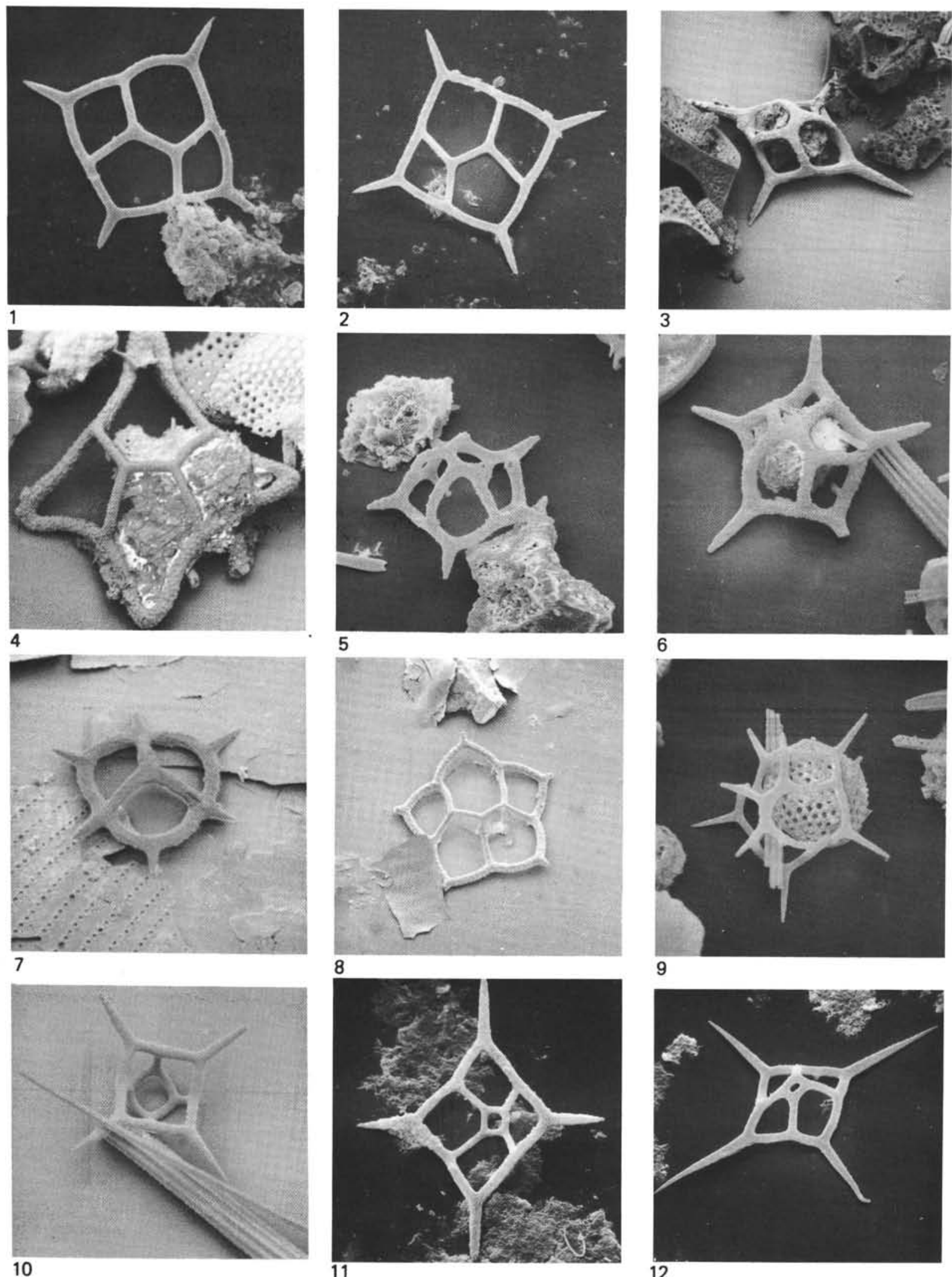


\section{PLATE 4}

Figure $1 \quad$ Mesocena apiculata (Schulz). Triangular form, SEM 550 $\times$; Sample 339-12-3, 115-116 cm; Naviculopsis biapiculata Zone.

Figure 1 Distephanus quinquangellus Bukry and Foster.

Distal side, SEM 450 $\times$;

Sample 348-14-1, 90-91 cm;

Mesocena circulus Zone.

Figure 2 Distephanus speculum (Ehrenberg).

Distal side, SEM 540×;

Sample 348-7-2, 30-31 cm;

Distephanus boliviensis Zone.

Figure 3 Distephanus speculum (Ehrenberg).

Distal side, SEM 450×;

Sample 348-11-2, 85-86 cm;

Mesocena circulus Zone.

Figure 4 Distephanus speculum (Ehrenberg).

Proximal side, SEM 500×;

Sample 348-11-1, 20-21 cm;

Mesocena circulus Zone.

Figures 5,6 Distephanus boliviensis (Frenguelli).

Sample 348-7-2, 30-31 cm;

Distephanus boliviensis Zone.

5. Distal side, SEM $540 \times$.

6. Distal side, SEM $500 \times$.

Figures 7,8

Figure 4

Figures 5, 6

Figure 2

Figure 3

Mesocena apiculata (Schulz).

Rounded triangular form, SEM $500 \times$;

Sample 348-15, CC;

Mesocena circulus Zone.

Mesocena oamaruensis Schulz.

SEM 450 $\times$;

Sample 340-7, CC;

Corbisema bimucronata Zone.

Mesocena diodon Ehrenberg.

Normal two-spined form, SEM 550X;

Sample 348-11-2, 20-21 cm;

Mesocena circulus Zone.

Mesocena elliptica Ehrenberg.

Normal four-spined form;

Mesocena circulus Zone.

5. Sample $348-11-2,20-21 \mathrm{~cm}$, SEM $550 \times$.

6. Sample $348-11-1,20-21 \mathrm{~cm}, \mathrm{SEM}$ $500 \times$.

Mesocena circulus Ehrenberg.

Sample 348-11-2, 20-21 cm;

Mesocena circulus Zone.

7. Flat view, SEM $550 \times$.

8. Side view, SEM $500 \times$.

Figure $9 \quad$ Naviculopsis navicula (Ehrenberg).

Distal side, SEM 550X;

Sample 338-13-3, 5-6 cm;

Naviculopsis navicula Zone.

(irculus Zone.

8. Side view, SEM $925 \times$.

9. Side view, SEM $950 \times$.

10. Oblique view from below, SEM $950 \times$.

Figures 11, 12 Cannopilus depressus (Ehrenberg).

Distal sides, SEM 900X;

Mesocena circulus Zone.

11. Sample 348-15, CC.

12. Sample 348-14-1, 90-91 cm.

(see page 880 )
Figure 10

Naviculopsis iberica Deflandre.

Distal side, SEM 500×;

Sample 338-17, CC;

Naviculopsis navicula Zone.

Figure 11

Naviculopsis lata (Deflandre).

Proximal side, SEM 500X;

Sample 338-17, CC;

Naviculopsis navicula Zone.

Figure 12
Naviculopsis quadratum (Ehrenberg).

Distal side, SEM 500×;

Sample 338-13-3, 5-6 cm;

Naviculopsis navicula Zone.

(see page 881 ) 
PLATE 3
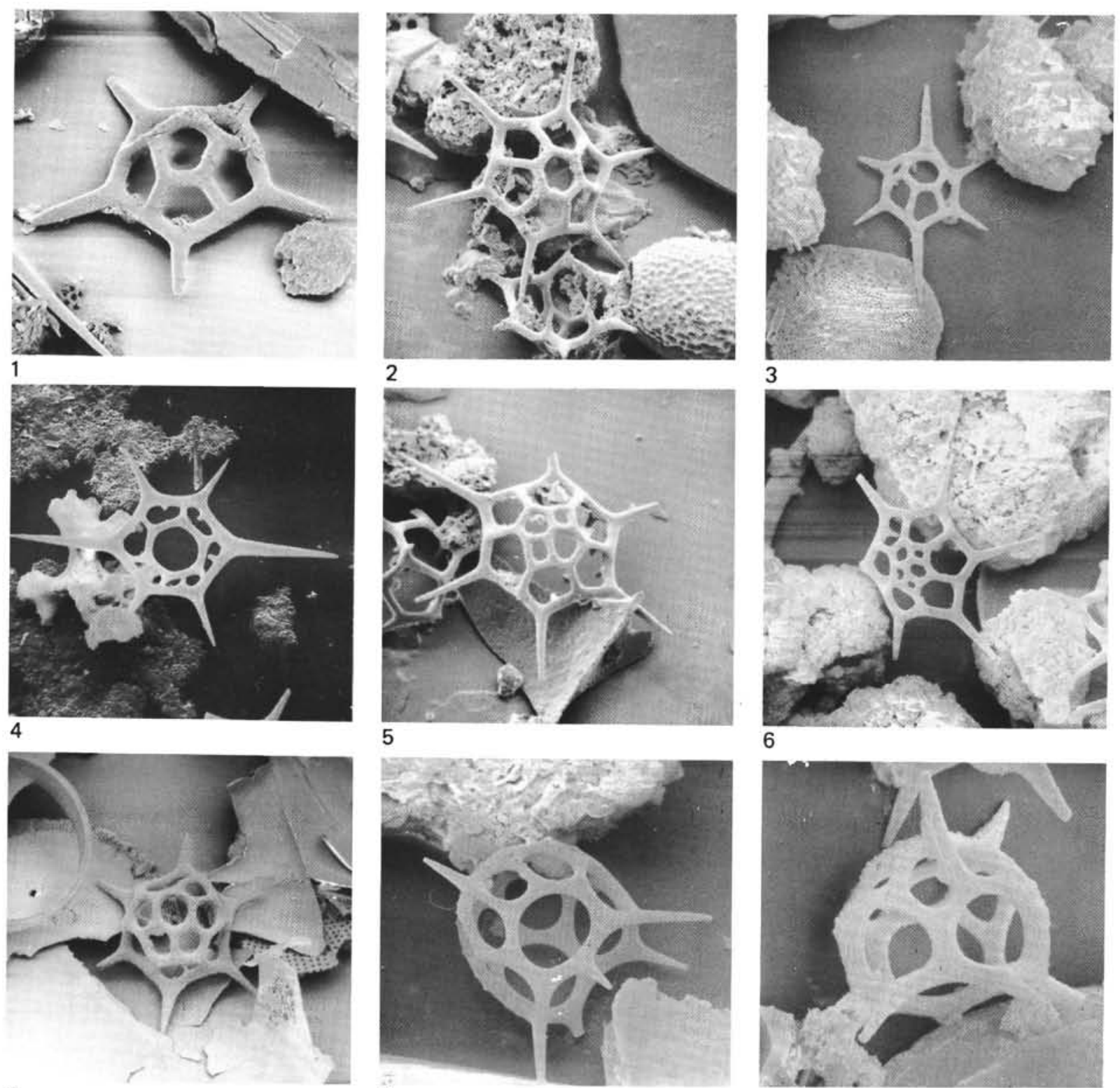

5
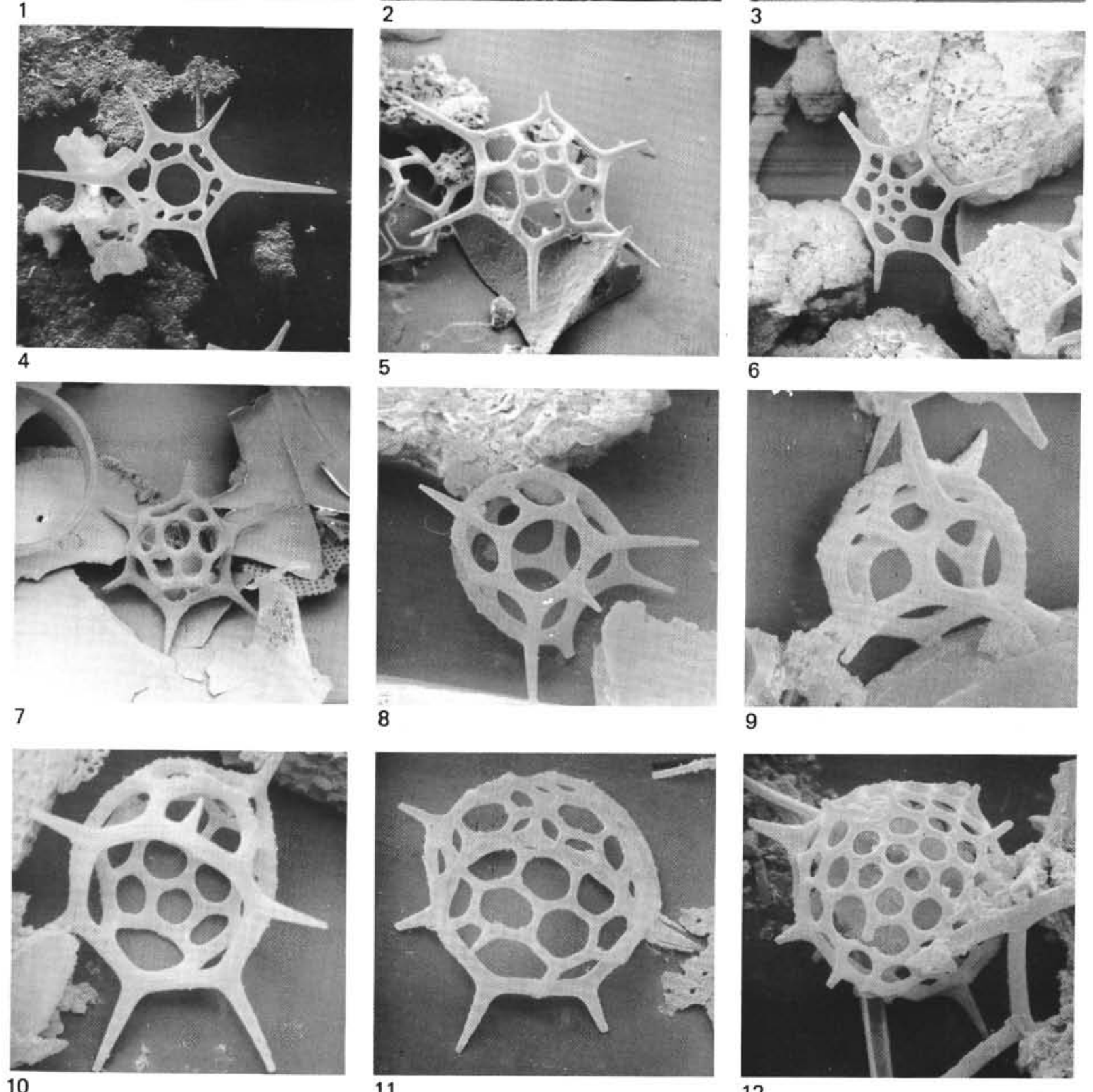

12 
PLATE 4
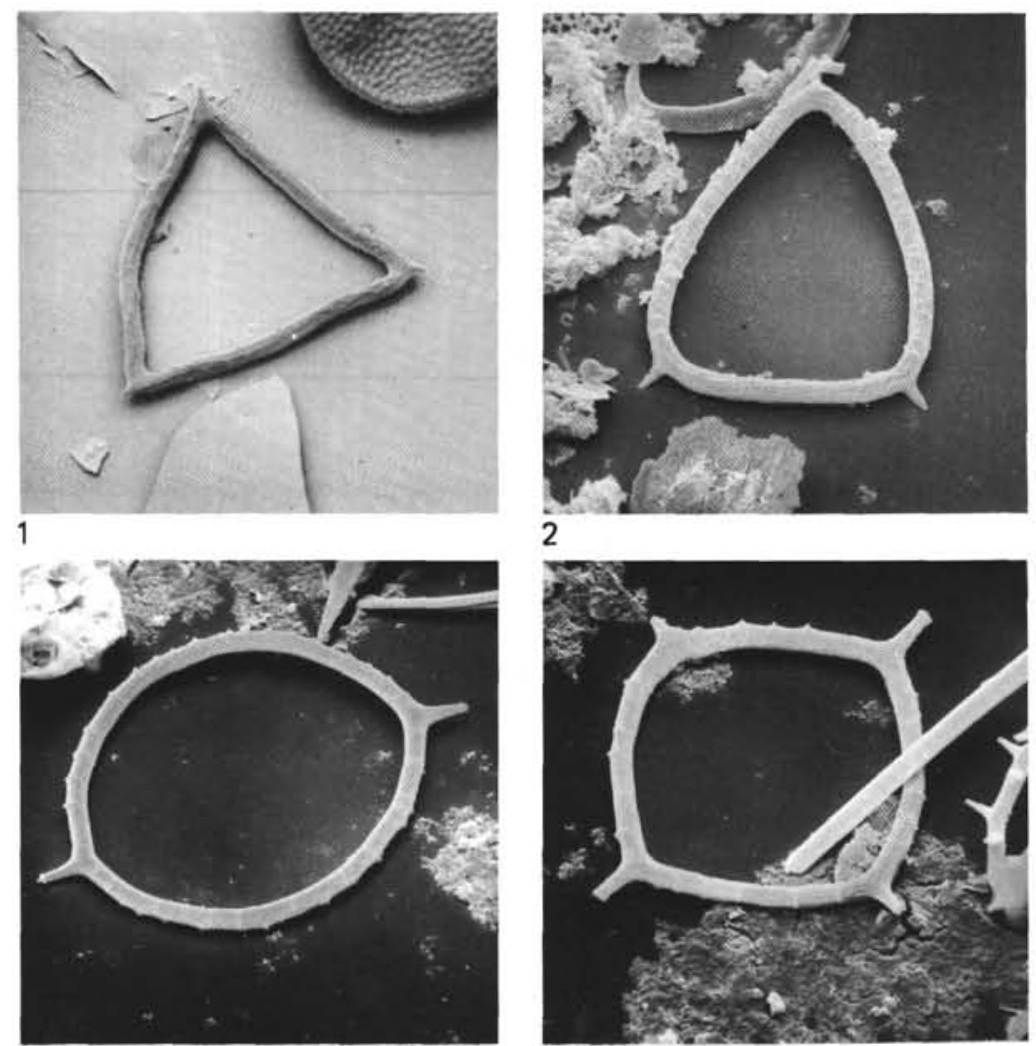

2
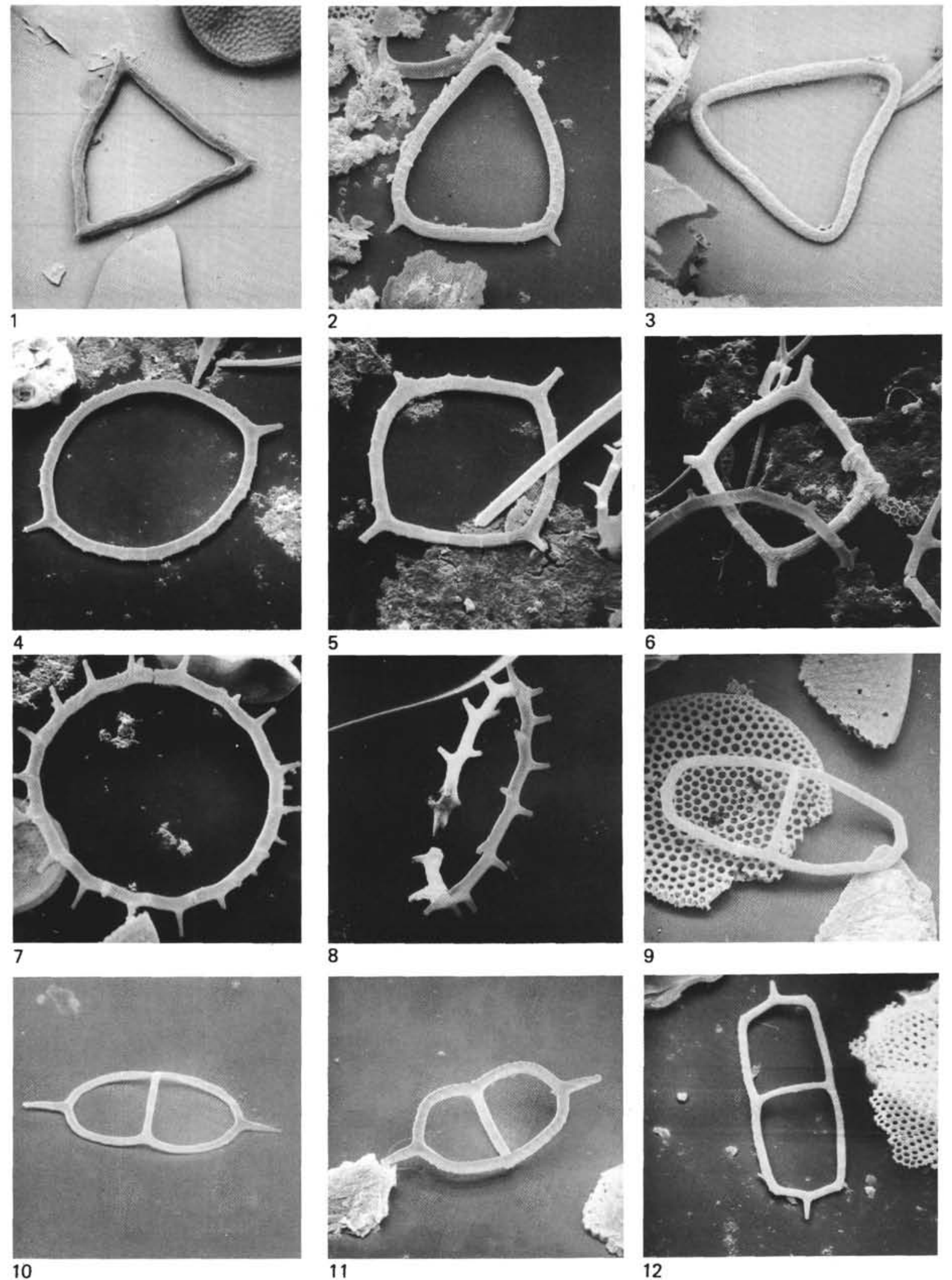


\section{PLATE 5}

Figure $1 \quad$ Naviculopsis constricta (Schulz).

Distal side, SEM 500X;

Sample 339-10-2, 55-56 cm;

Naviculopsis navicula Zone.

Figures 2, 3 Naviculopsis ponticula Perch-Nielsen.

Sample 340-1, CC;

Corbisema bimucronata Zone.

2. Distal side, SEM $270 \times$.

3. Side view, SEM $550 \times$.

Figure $4 \quad$ Corbisema apiculata (Lemmermann).

SEM 2500X;

Sample 339-7, CC;

Distephanus speculum Zone (reworked).

Figure $5 \quad$ Corbisema apiculata (Lemmermann).

SEM 2550X;

Sample 340-11, CC;

Corbisema bimucronata Zone.

Figure 6 Corbisema sp. SEM $2300 \times$ (see Plate 1, Figure 11);

Sample 339-7, CC.

Distephanus speculum Zone (displaced

Figure 7 Dictyocha $\mathrm{cf}$. epiodon Ehrenberg.

SEM 2500 $\times$;

Sample 339-12-3, 125-126 cm;

Naviculopsis biapiculata Zone.

Figure 8 Dictyocha $\mathrm{cf}$. fibula Ehrenberg.

SEM 2400×;

Sample 339-12-3, 125-126 cm;

Naviculopsis biapiculata Zone.

Figure 9 Dictyocha quadria (Mandra).

SEM 1000× (see Plate 2, Figure 4);

Sample 340-11, CC;

Corbisema bimucronata Zone.

Figure 10 Dictyocha challengeri $\mathrm{n} . \mathrm{sp}$.

SEM 1100× (see Plate 2, Figure 8);

Sample 339-12-3, 115-116 cm;

Naviculopsis biapiculata Zone.

Figure 11 Dictyocha pentagona (Schulz).

SEM 2250× (see Plate 2, Figure 5);

Sample 340-11, CC;

Corbisema bimucronata Zone.

Figure 12 Distephanus boliviensis (Frenguelli).

SEM 2500× (see Plate 3, Figure 6);

Sample 348-7-2, 30-31 cm;

Distephanus boliviensis Zone.

\section{PLATE 6}

Figure 1

Distephanus speculum (Ehrenberg).

Sample 348-11-2, 85-86 cm;

Mesocena circulus Zone.
a. SEM $2250 \times$.
b. SEM $4500 \times$.
c. SEM $4500 \times$.

Figures 2-4

Cannopilus ernestinae Bachmann.

Sample 348-15, CC;

Mesocena circulus Zone.

2. SEM $2450 \times$ (see Plate 3, Figure 10).

3. SEM $2400 \times$ (see Plate 3, Figure 9).

4. SEM $2300 \times$.

Figure 5

Mesocena apiculata (Schulz).

SEM 1000X;

Sample 339-12-3, 115-116 cm;

Naviculopsis biapiculata Zone.

Figure $6 \quad$ Mesocena elliptica (Schulz).

SEM 5525× (see Plate 4, Figure 6); Sample 348-11-1, 20-21 cm;

Mesocena circulus Zone.

Figure 7

Mesocena diodon Ehrenberg.

SEM 2650X;

Sample 348-11-1, 20-21 cm;

Mesocena circulus Zone.

Figure 8

Naviculopsis ponticula Perch-Nielsen. SEM 2500X;

Sample 340-11, CC;

Corbisema bimucronata Zone.

Figures 9, 10 Naviculopsis lata (Deflandre).

Sample 338-17, CC;

Naviculopsis navicula Zone.

9. SEM $2500 \times$.

10. SEM $2500 \times$ (see Plate 4 , Figure 11). 
PLATE 5
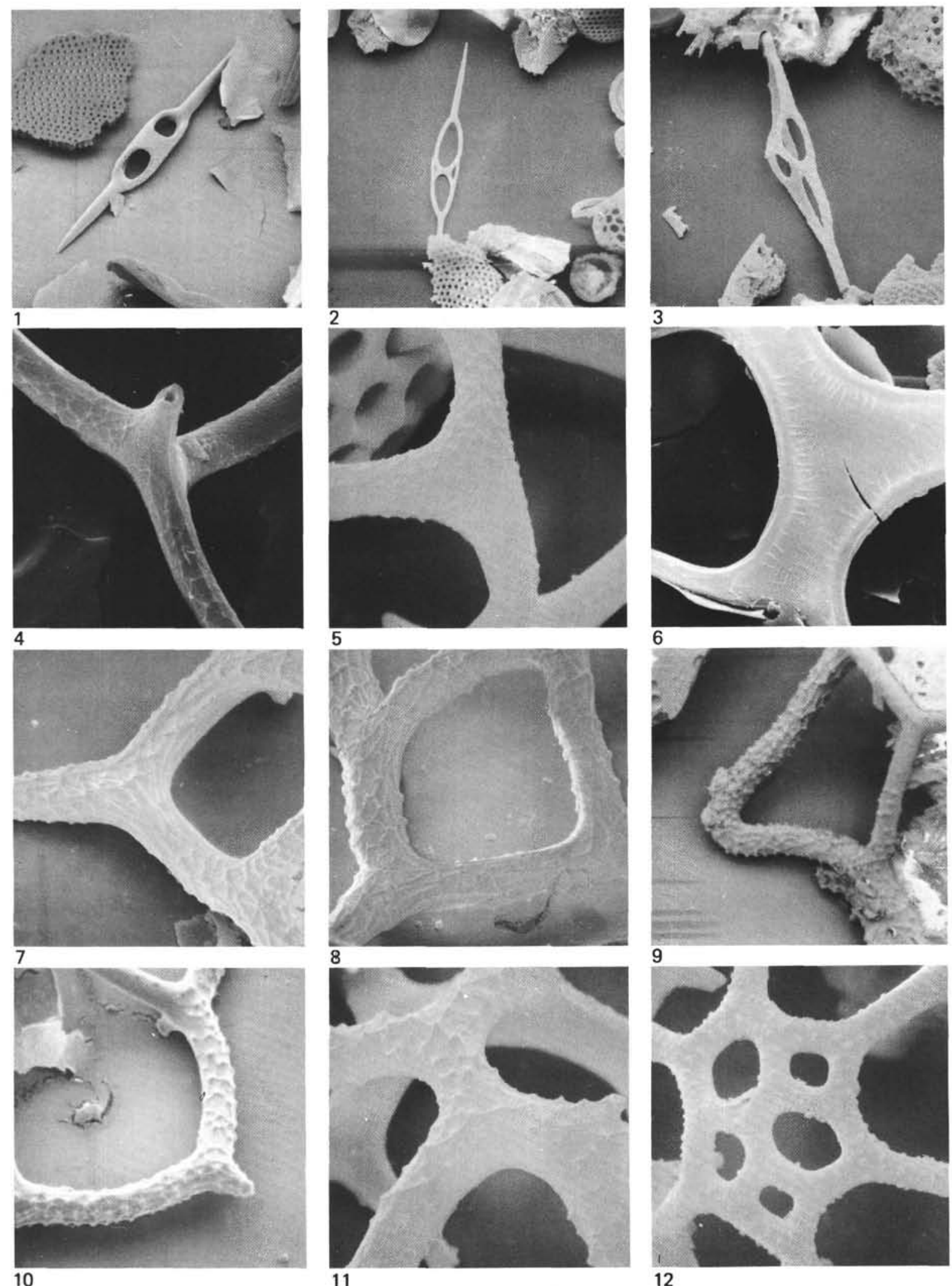
PLATE 6

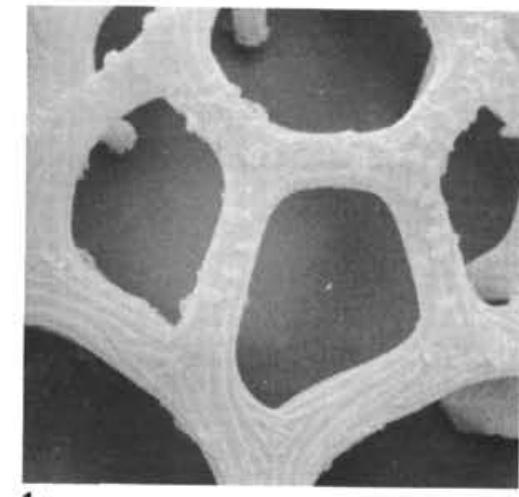

1a
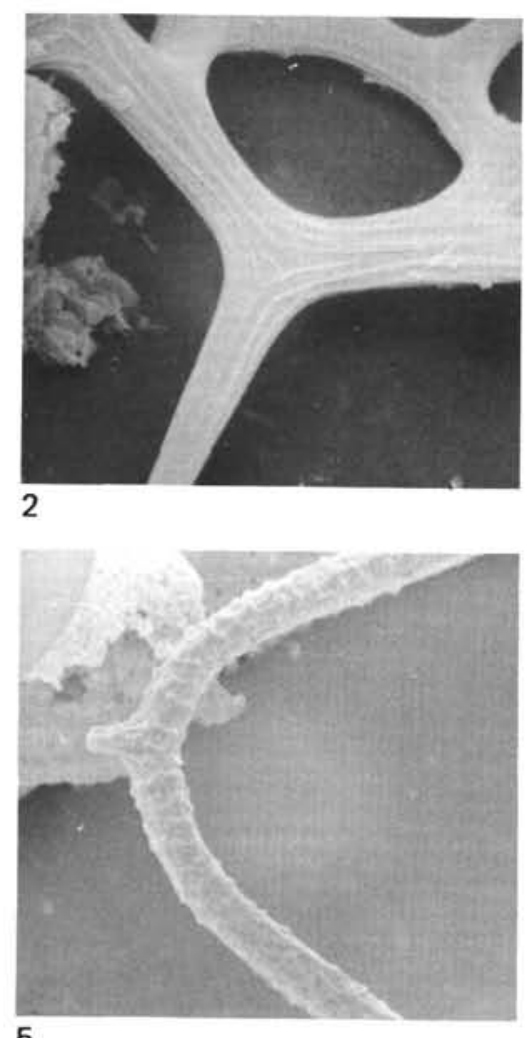

5

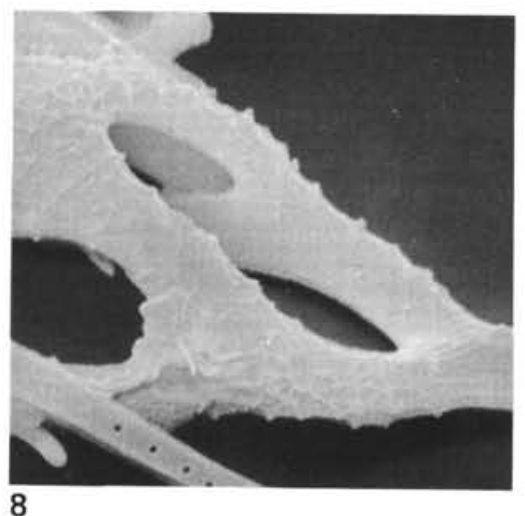

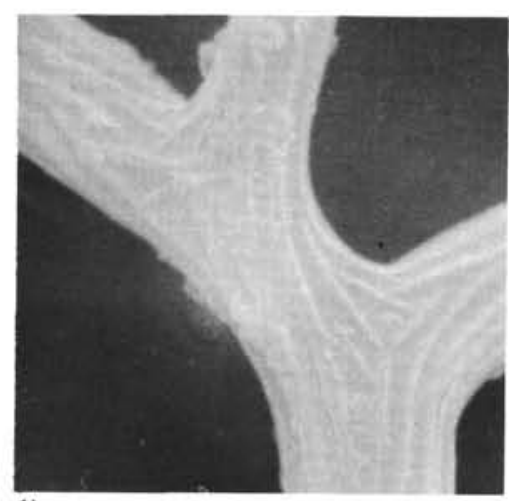

$1 b$

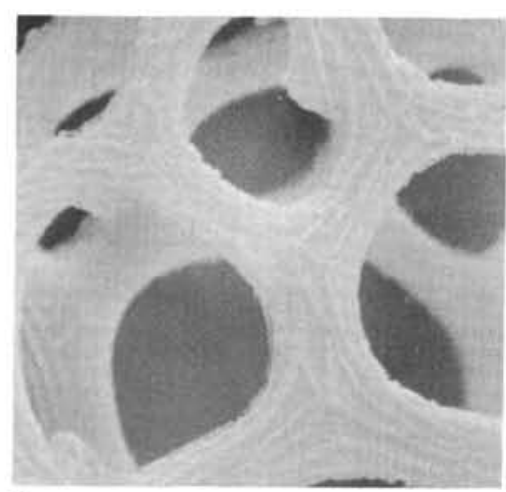

3
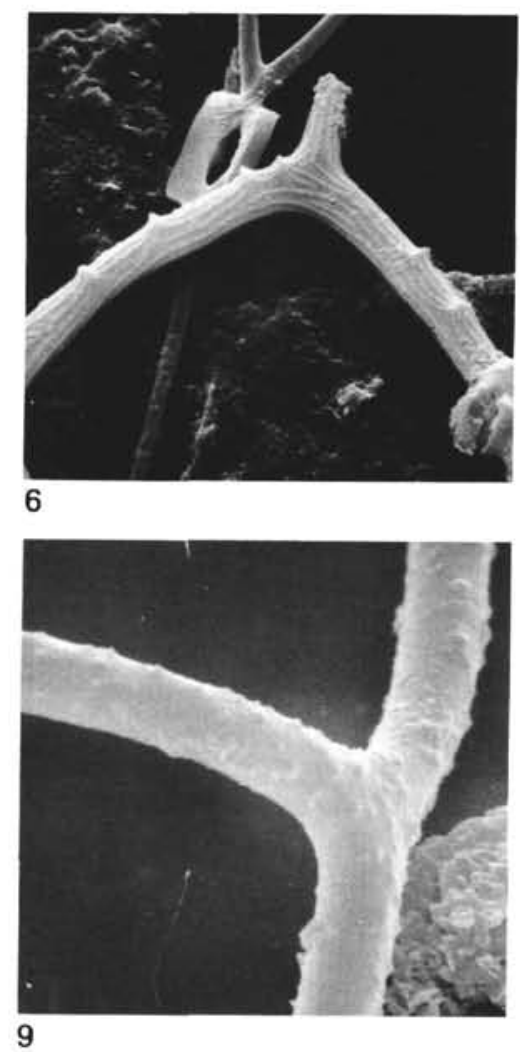
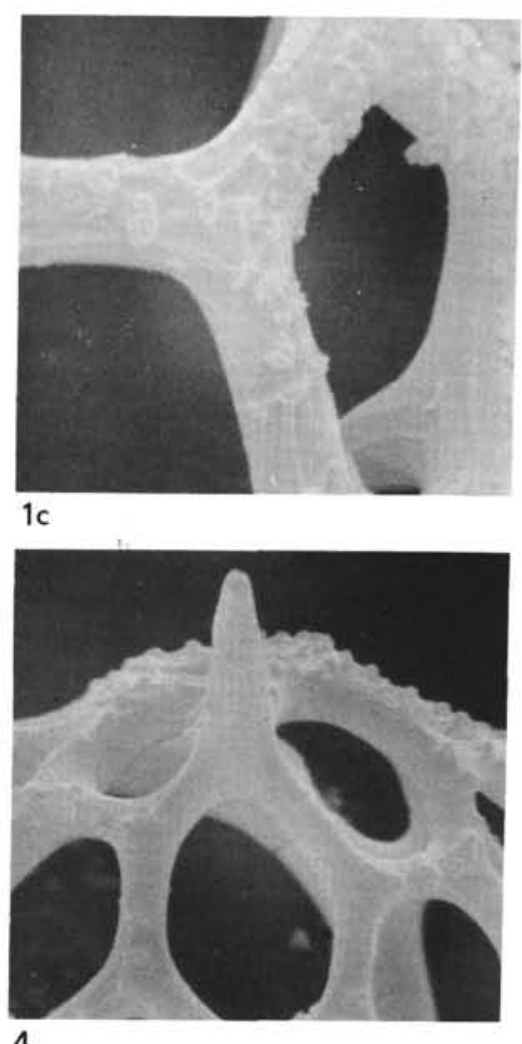

4
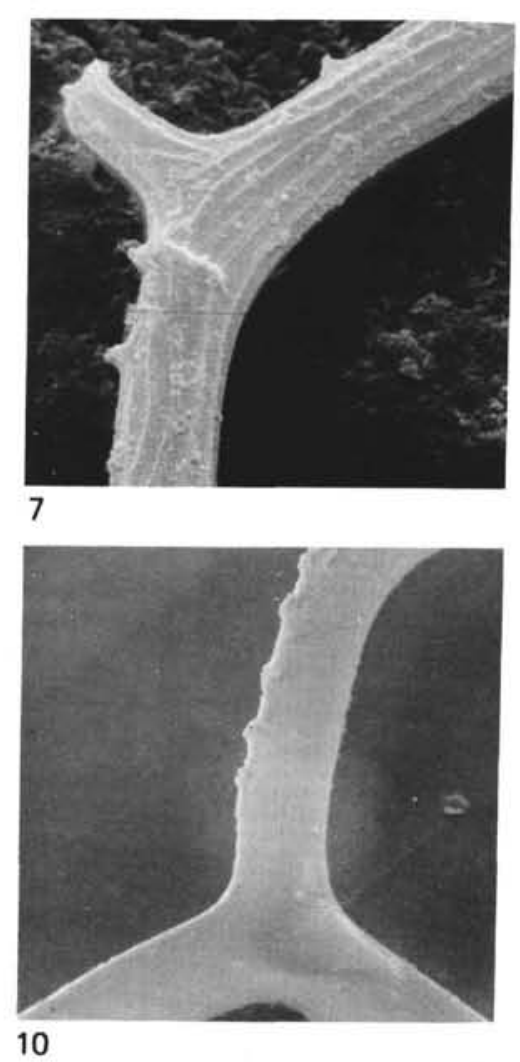


\section{PLATE 7}

(All specimens LM and except Figure 12 approximately $400 \times$ )

Figures 1,2 Corbisema apiculata (Lemmermann). Proximal side.

1. Sample 339-12-3, 125-126 cm; Naviculopsis biapiculata Zone.

2. Sample 343-5-4, 120-121 cm; Naviculopsis minor Zone.

Figures 3, 4 Corbisema ovalis Perch-Nielsen.

3. Proximal side;

Sample 340-7, CC;

Corbisema bimucronata Zone.

4. Distal side;

Sample 340-5, CC;

Naviculopsis foliacea Zone (?).

Figure 5 Corbisema cf. archangelskiana (Schulz).

Proximal side;

Sample 340-7, CC;

Corbisema bimucronata Zone.

Figure $6 \quad$ Corbisema cf. flexuosa (Stradner).

Distal side;

Sample 339-12-3, 125-126 cm;

Naviculopsis bimucronata Zone.

Figure 7 Corbisema flexuosa (Stradner).

Distal side;

Sample 338-13-2, 85-86 cm;

Naviculopsis navicula Zone.

Figure $8 \quad$ Dictyocha $\mathrm{sp}$.

Distal side;

Sample 340-4-3, 100-101 cm;

Naviculopsis foliacea Zone (?).

Figure 9 Corbisema spinosa Deflandre.

Distal side, (a) high focus, (b) medium focus;

Sample 339-10, CC;

Naviculopsis biapiculata Zone.

Figure $10 \quad$ Dictyocha hexacantha Schulz.

Proximal side;
Sample 339-12-3, 115-116 cm;

Naviculopsis biapiculata Zone.

Figure $11 \quad$ Dictyocha deflandrei Frenguelli.

Proximal side;

Sample 343-5-4, 25-26 cm;

Naviculopsis minor Zone.

Figure 12 Corbisema bimucronata Deflandre.

Distal side, approx. 350×;

Sample 340-8, CC;

Corbisema bimucronata Zone.

Figure $13 \quad$ Dictyocha sp.

Distal side, (a) medium focus, (b) high focus;

Sample 340-4-3, 100-101 cm;

Naviculopsis foliacea Zone (?).

Figure 14 Dictyocha $\mathrm{cf}$ transitoria Deflandre.

Distal side, (a) medium focus, (b) high focus;

Sample 343-5-4, 25-26 cm;

Naviculopsis minor Zone.

Figure 15 Distephanus crux (Ehrenberg).

Distal side;

Sample 338-15-1, 95-96 cm;

Naviculopsis navicula Zone.

Figure 16 Dictyocha rotundata Jousé.

Distal side, (a) medium focus, (b) high focus:

Sample 343-5-6, 110-111 cm;

Naviculopsis minor Zone.

Figures 17, 18 Distephanus antiquus Glezer.

Naviculopsis minor Zone.

17. Five-sided specimen, medium focus;

Sample 343-5-3, 100-101 cm.

18. Six-sided specimen, (a) medium focus, (b) high focus;

Sample 343-5-2, $125-126 \mathrm{~cm}$. 


\section{PLATE 7}

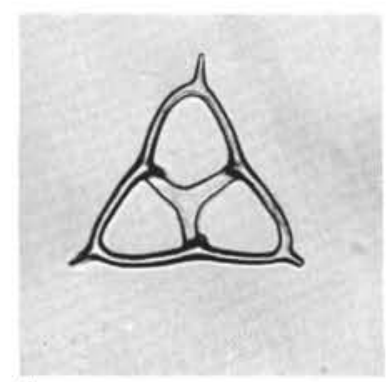

1
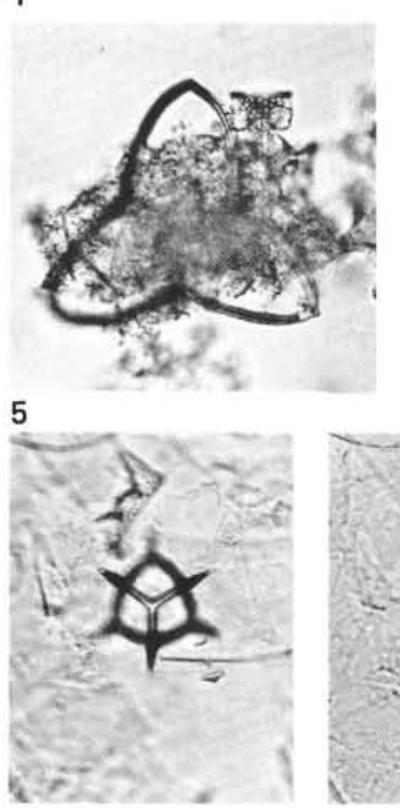

$9 a$

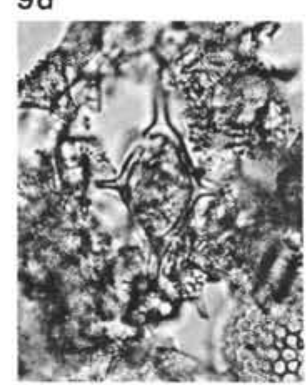

$13 a$

or

. $x, 1,0$ स्थे हो and 2

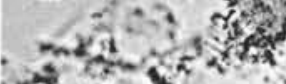
$x^{2}+\mathrm{di}^{2} \mathrm{x}$ $16 a$

$9 \mathrm{~b}$

$13 b$ $16 \mathrm{~b}$

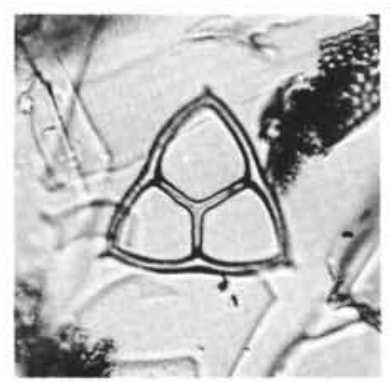

2

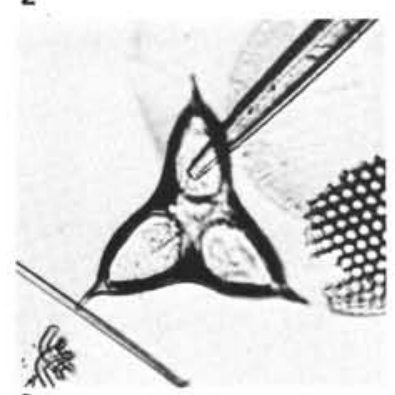

6
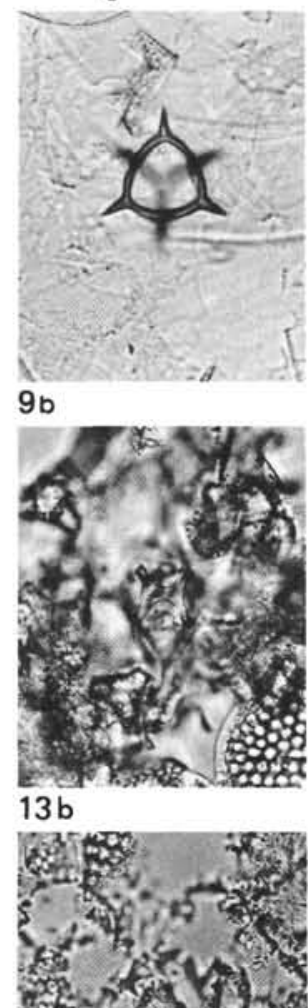

cxity
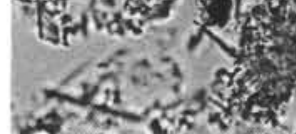

$x=58$ dis

10

$14 a$

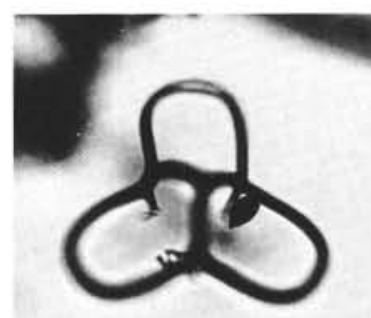

3

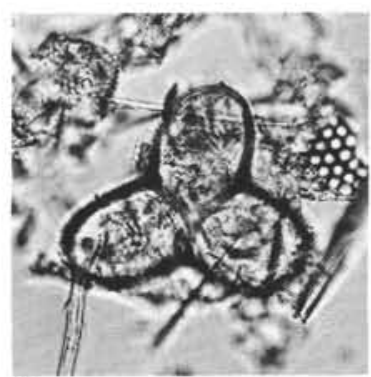

4

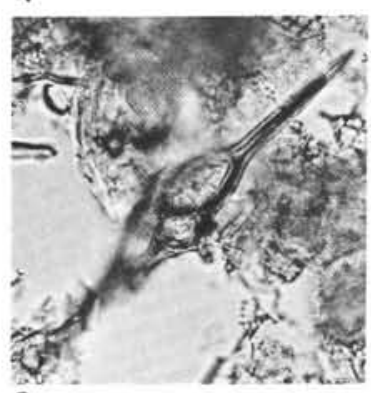

8
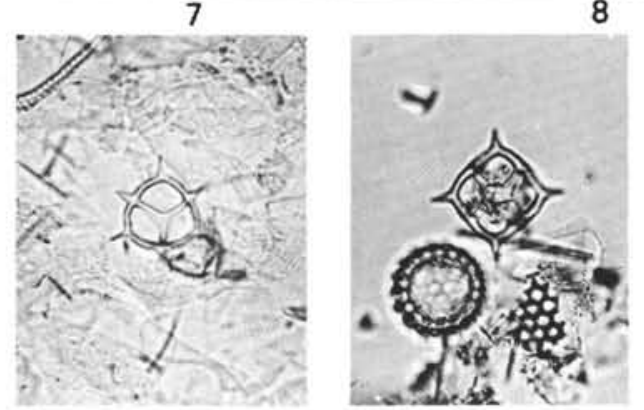

11
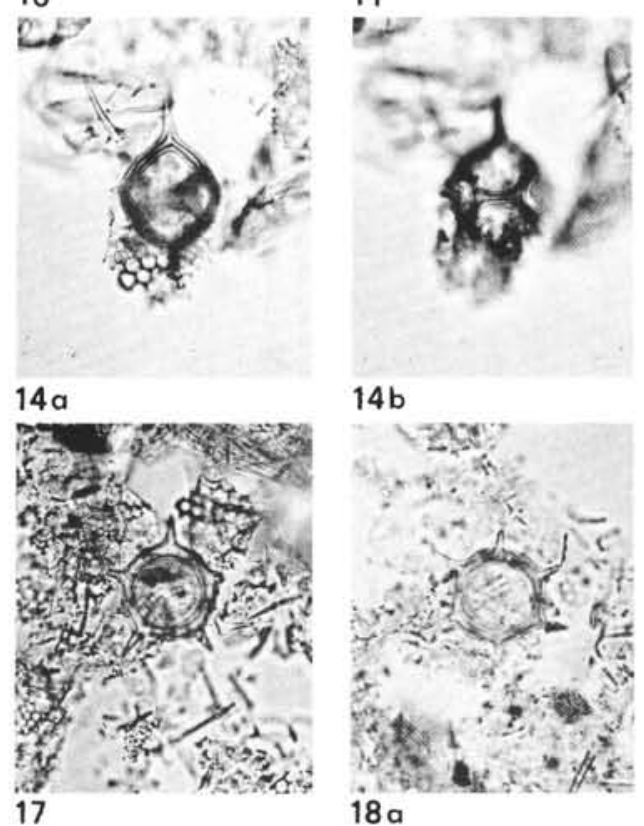

$14 \mathrm{~b}$
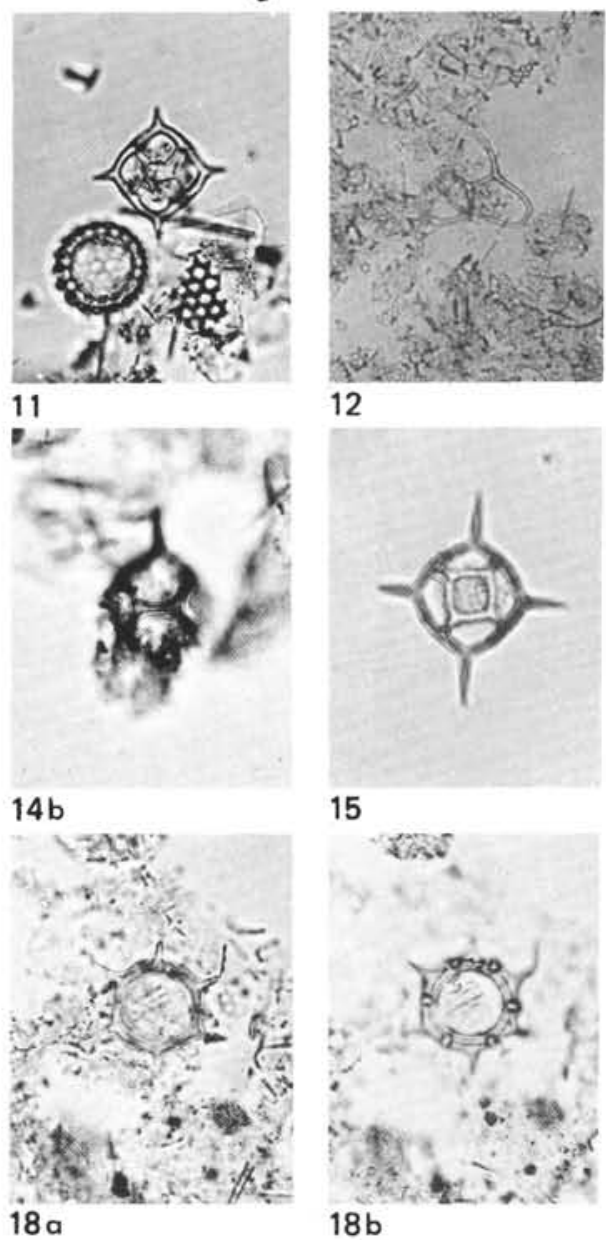

12

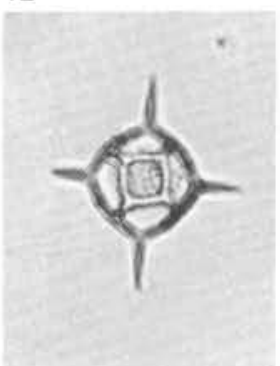

15

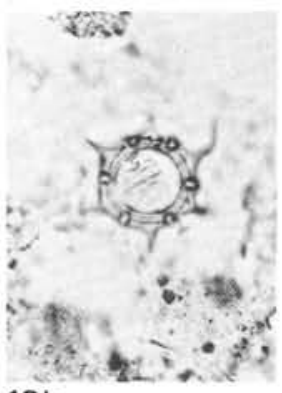

$18 \mathrm{~b}$ 


\section{PLATE 8}

(All specimens LM and except Figures 15-17 approximately $400 \times$.)

Figure 1 Dictyocha cf. epiodon Ehrenberg. Distal side; Sample 348-14-1, 90-91 cm; Mesocena circulus Zone.

Figure 2 Dictyocha cf. fibula Ehrenberg. Proximal side;

Sample 348-14-6, 85-86 cm; Mesocena circulus Zone.

Figure 3 Dictyocha challengeri $\mathrm{n}$. sp. Holotype SM.B 12796, proximal side; Sample 339-12-3, 125-126 cm; Naviculopsis biapiculata Zone.

Figure 4 Dictyocha cf. fibula Ehrenberg.

Proximal side;

Sample 339-7, CC;

Distephanus speculum Zone (reworked).

Figure 5 Dictyocha pentagona (Schulz).

Distal side;

Sample 340-11, CC;

Corbisema bimucronata Zone.

Figure $6 \quad$ Dictyocha sp.

Distal side;

Sample 339-10, CC;

Naviculopsis biapiculata Zone.

Figure 7 Dictyocha torta $\mathrm{n}$. sp.

Holotype SM.B 12797, (a) medium focus, (b) high focus;

Sample 338-26-2, 109-110 cm;

Dictyocha quadria Zone.

Figures 8, 9 Dictyocha pentagona (Schulz).

Naviculopsis navicula Zone.

8. Five-sided specimen;

Sample 338-17-2, 25-26 cm.

9. Six-sided specimen;

Sample 338-17-2, 135-136 cm.
Figure 10

Cannopilus sp.

Side view;

Sample 338-20-2, 30-31 cm;

Naviculopsis biapiculata Zone.

Figure 11

Distephanus longispinus (Schulz).

Proximal side, (a) medium focus, (b) low focus;

Sample 338-10, CC;

Corbisema triacantha Zone.

Figure 12 Distephanus speculum (Ehrenberg).

Side view of tilted specimen;

Sample 348-6, CC;

Distephanus boliviensis Zone.

Figure 13 Distephanus octonarius (Ehrenberg).

Distal side;

Sample 348-5, CC;

Distephanus speculum Zone.

Figure 14

Pseudorocella corona Deflandre.

Distal side;

Sample 338-17-2, 40-41 cm;

Naviculopsis navicula Zone.

Figure 15

Dictyocha quadria (Mandra).

Distal side, approx. 630X;

Sample 65/1-8, CC;

Corbisema bimucronata Zone.

Figure 16

Mass occurrence of diatom $340(=T r i-$ ceratium barbadense), approx. $380 \times$;

Sample 340-7, CC;

Corbisema bimucronata Zone.

Figure 17

Mass occurrence of diatom 348 (= Stephanogonia horridus), approx. $380 \times$;

Sample 348-16, CC;

Mesocena circulus Zone. 
PLATE 8
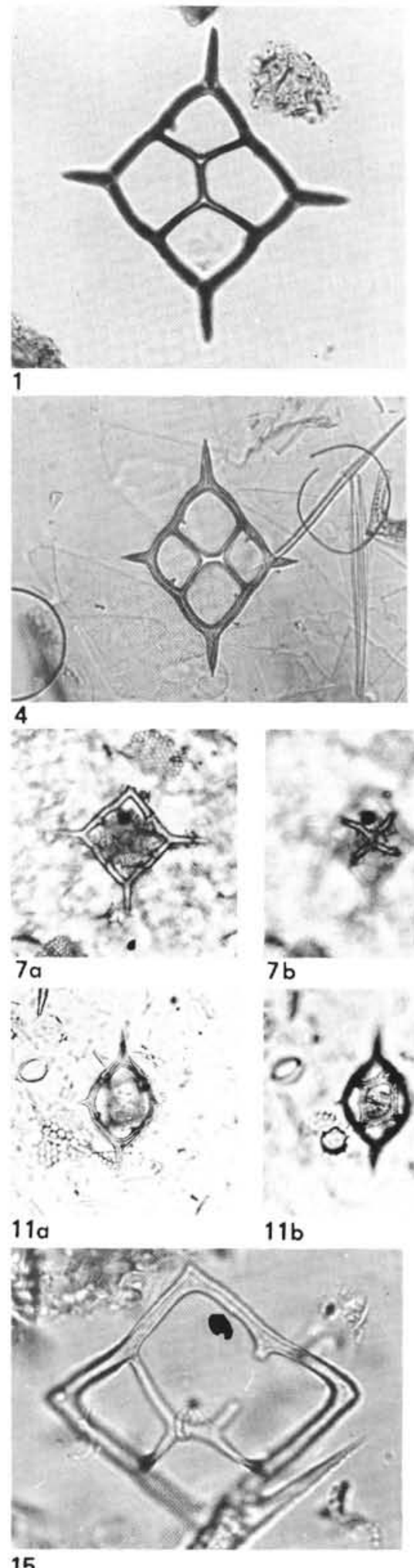
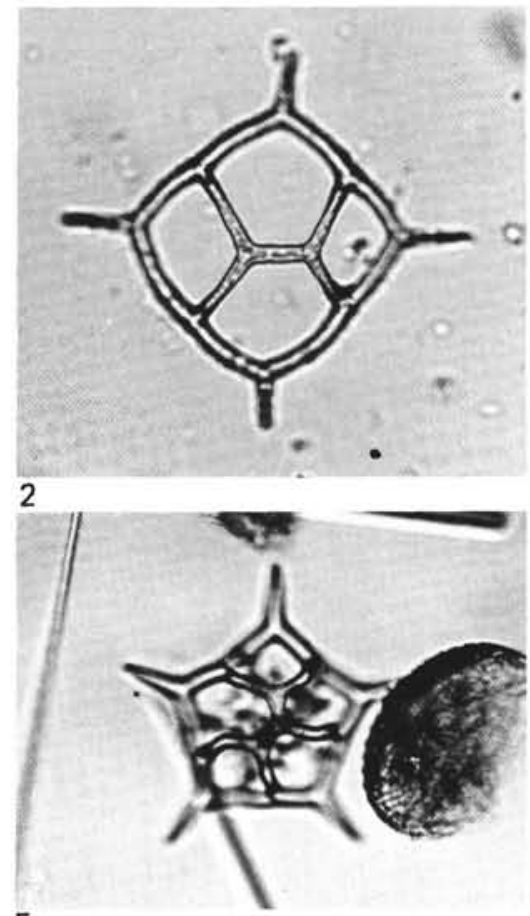

5

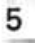

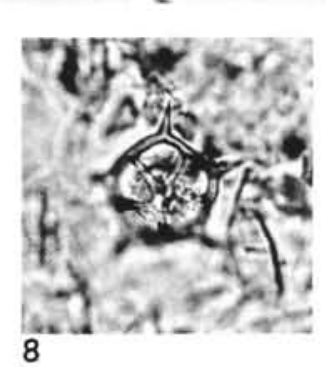
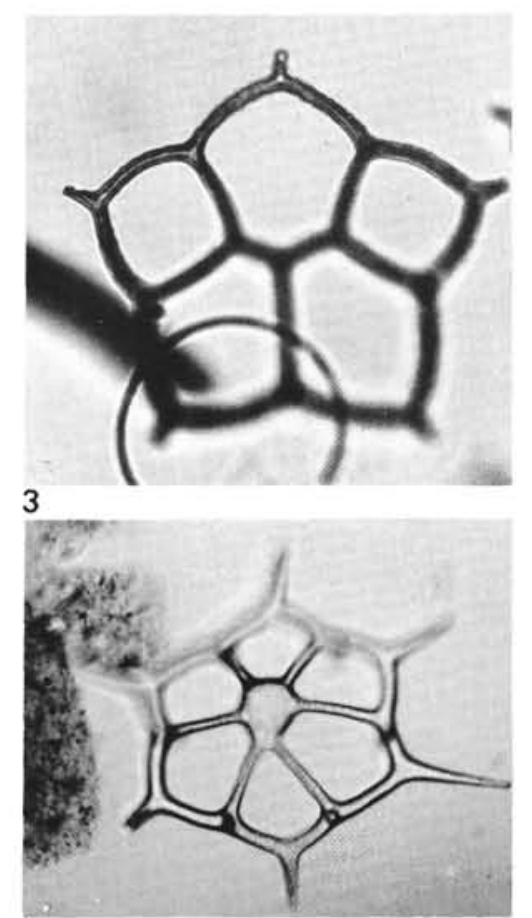

6
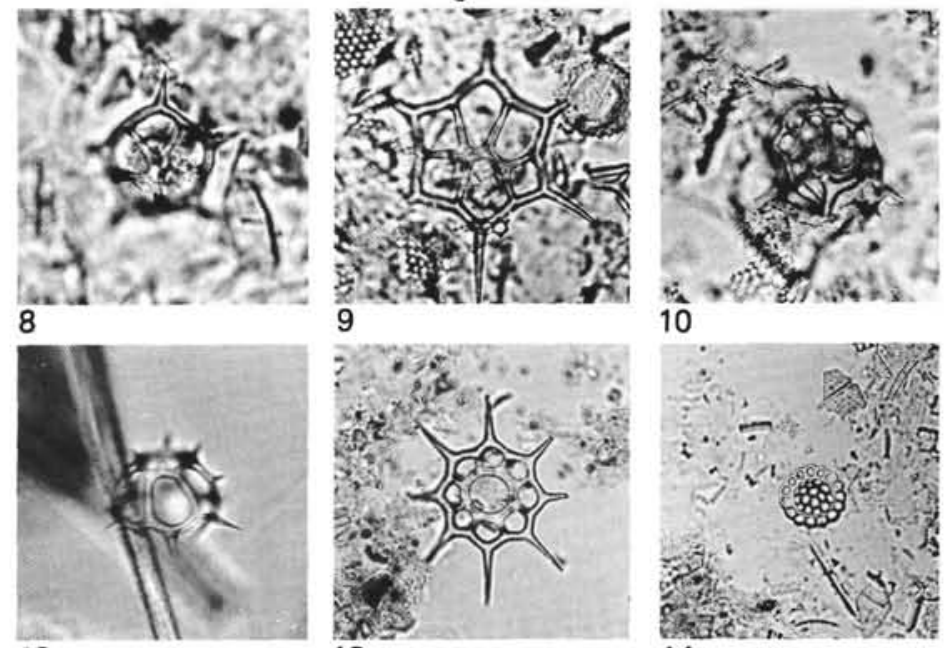

12

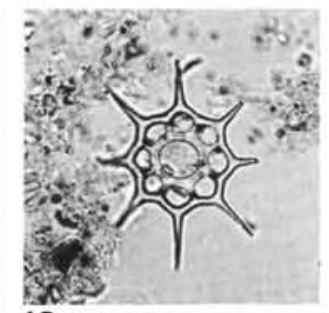

13
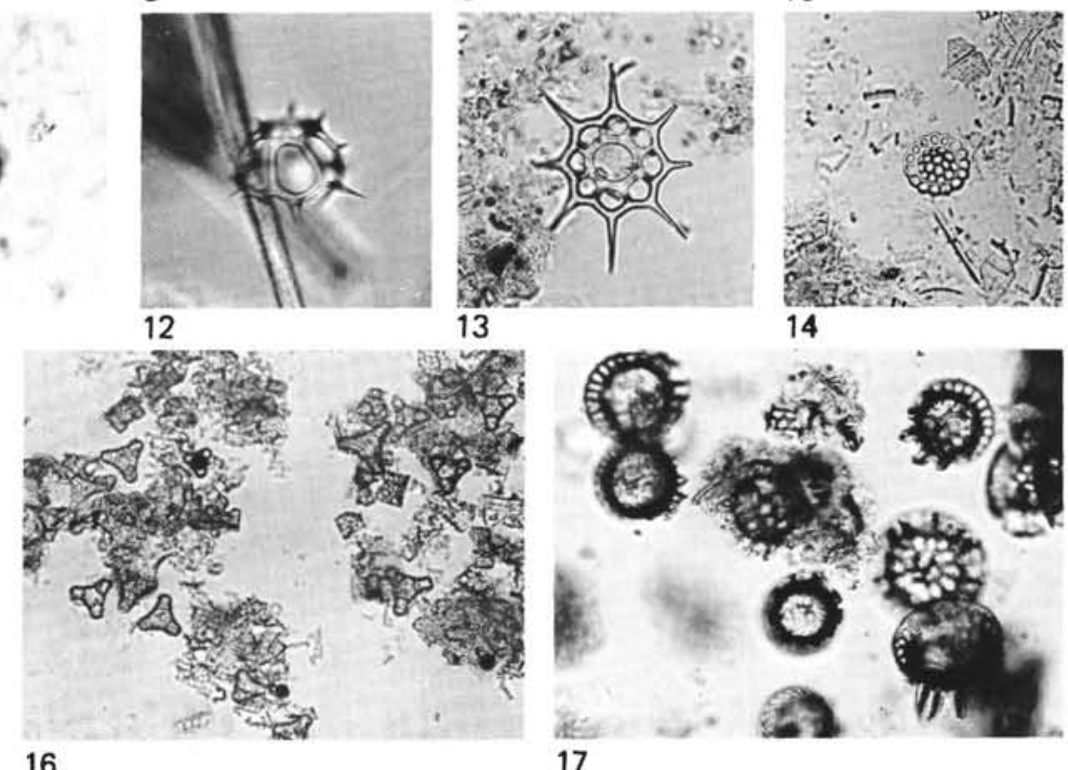

16

17 


\section{PLATE 9}

(All specimens LM and approximately $400 \times$.)

Figure $1 \quad$ Distephanus binoculus (Ehrenberg).

Distal side, (a) medium focus, (b) high focus;

Sample 348-11-1, 20-21 cm;

Mesocena circulus Zone.

Figure 2 Distephanus crux (Ehrenberg).

Distal side of aberrant specimen, (a) medium focus, (b) high focus;

Sample 338-7, CC;

Mesocena circulus Zone.

Figure 3 Distephanus boliviensis (Frenguelli).

Proximal side, (a) medium focus, (b) low focus;

Sample 348-6-1, 105-106 cm;

Distephanus boliviensis Zone.

Figure $4 \quad$ Distephanus quinquangellus Bukry and Foster.

Distal side, (a) medium focus, (b) high focus;

Sample 348-12-4, 90-91 cm;

Mesocena circulus Zone.

Figure $5 \quad$ Cannopilus hemisphaericus (Ehrenberg).

Distal side, (a) medium focus, (b) high focus;

Sample 338-19-4, 31-32 cm;

Naviculopsis biapiculata Zone.

Figures 6,7 Cannopilus ernestinae Bachmann.

Tilted specimens, (a) medium focus, (b) high focus;

Sample 338-7, CC;

Mesocena circulus Zone.

(See page 890)

\section{PLATE 10}

Figure $1 \quad$ Dictyocha quadria (Mandra).

Distal side, (a) medium focus, (b) high focus; LM 720 $\times$,

Sample 340-11, CC;

Corbisema bimucronata Zone.

Figure 2 Dictyocha quadria (Mandra).

Specimen with spherical-like protuberances on each corner;

Sample 283-6, CC (Leg 29);

Dictyocha quadria Zone.

a. Total view LM $680 \times$.

b. Left corner, medium focus, LM 1750×.

c. Left corner, high focus, LM $1750 \times$.

Figure $3 \quad$ Mesocena oamaruensis Schulz.

Specimen with spherical-like protuberances on each corner;

Sample 340-9, CC,

Corbisema bimucronata Zone.

a. Total view, LM $680 \times$.

b. Left corner, medium focus, LM 1750×.

c. Left corner, high focus, LM $1750 \times$.

Figures 4, 5 Mesocena cf. oamaruensis Schulz.

Spherical-like protuberances of broken specimens;

Corbisema bimucronata Zone.

4a. Medium focus, LM $400 \times$.

4b. High focus, LM 400×; Sample 340-9, CC.

5a. Medium focus, LM $400 \times$.

5b. High focus, LM 400×; Sample 340-11-2, 58- $59 \mathrm{~cm}$. 
PLATE 9

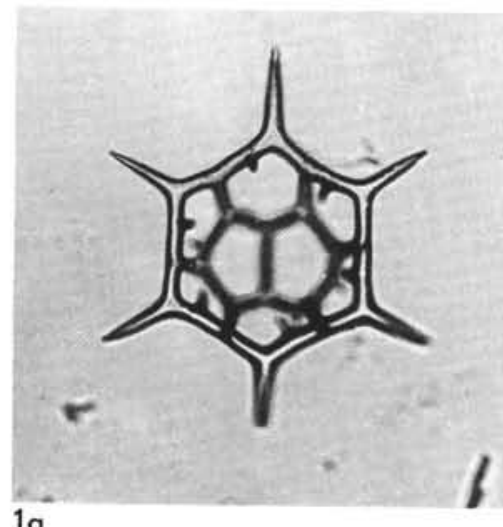

$1 a$

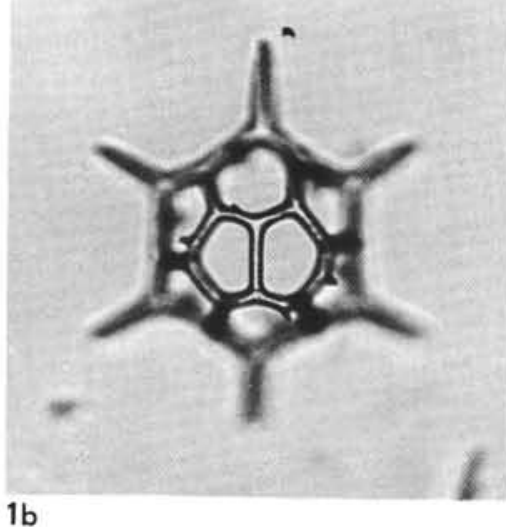

$1 b$
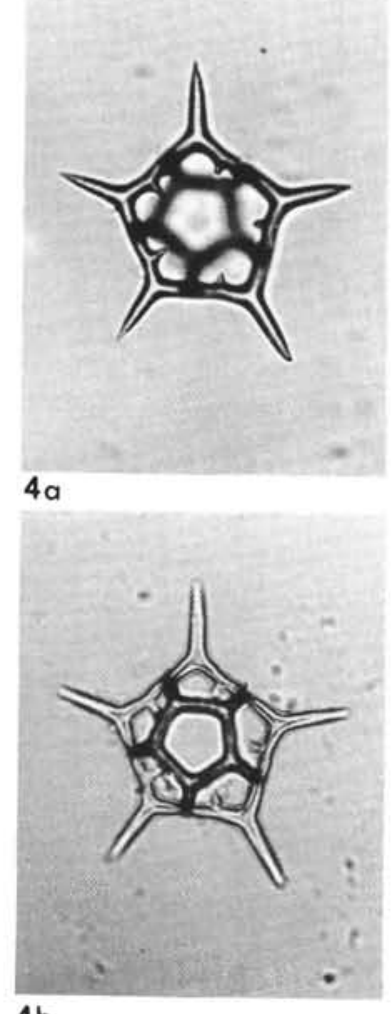

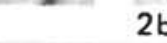

2 b

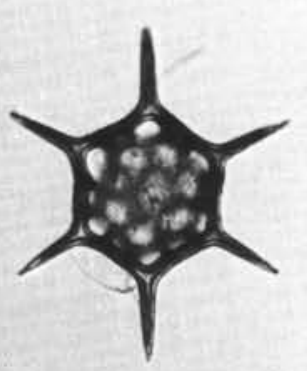

$5 a$

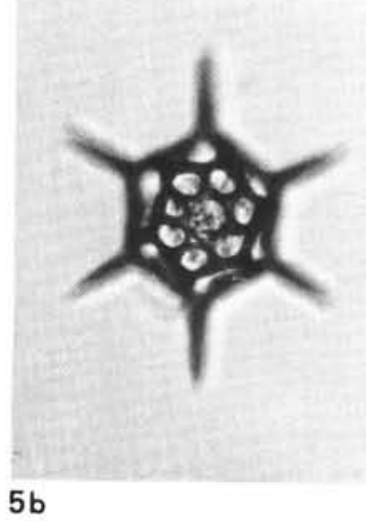

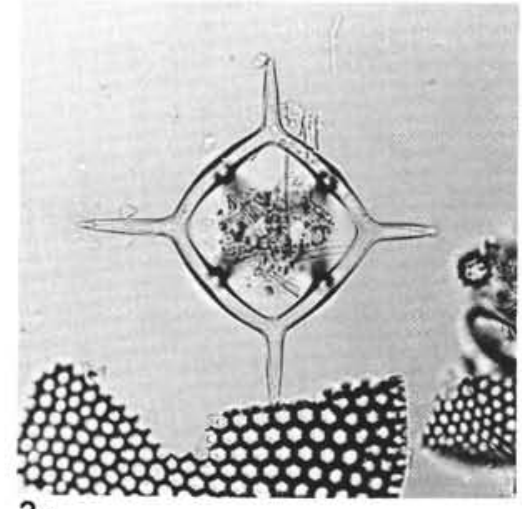

$2 a$
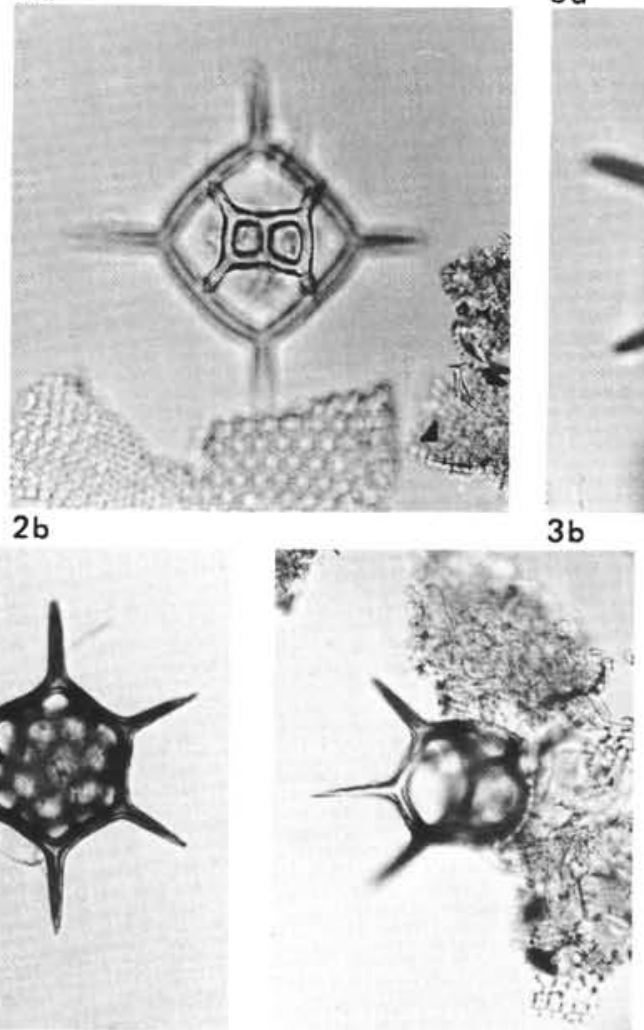

$6 a$

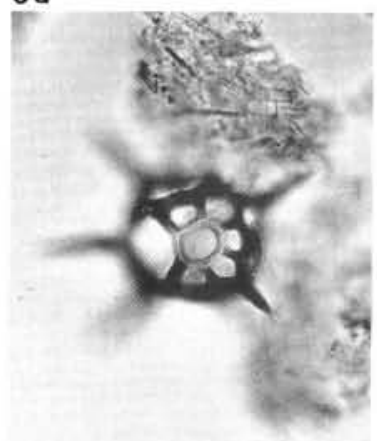

$6 b$

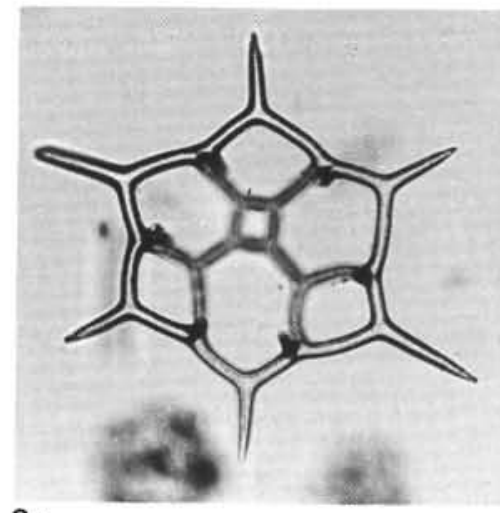

$3 a$
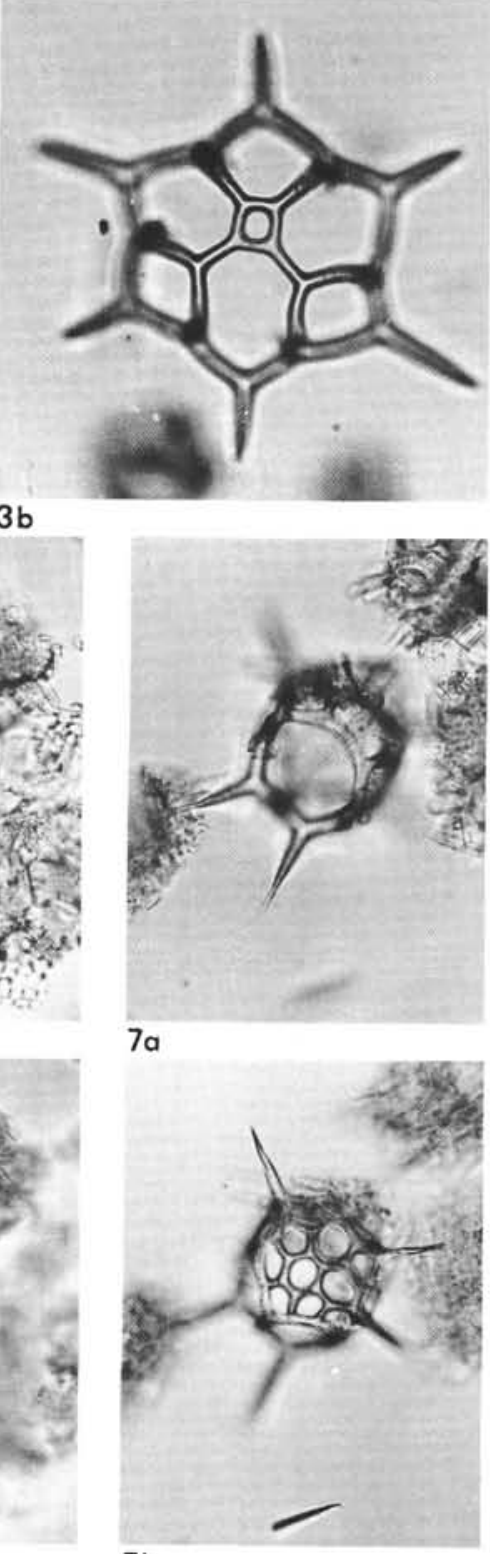
PLATE 10
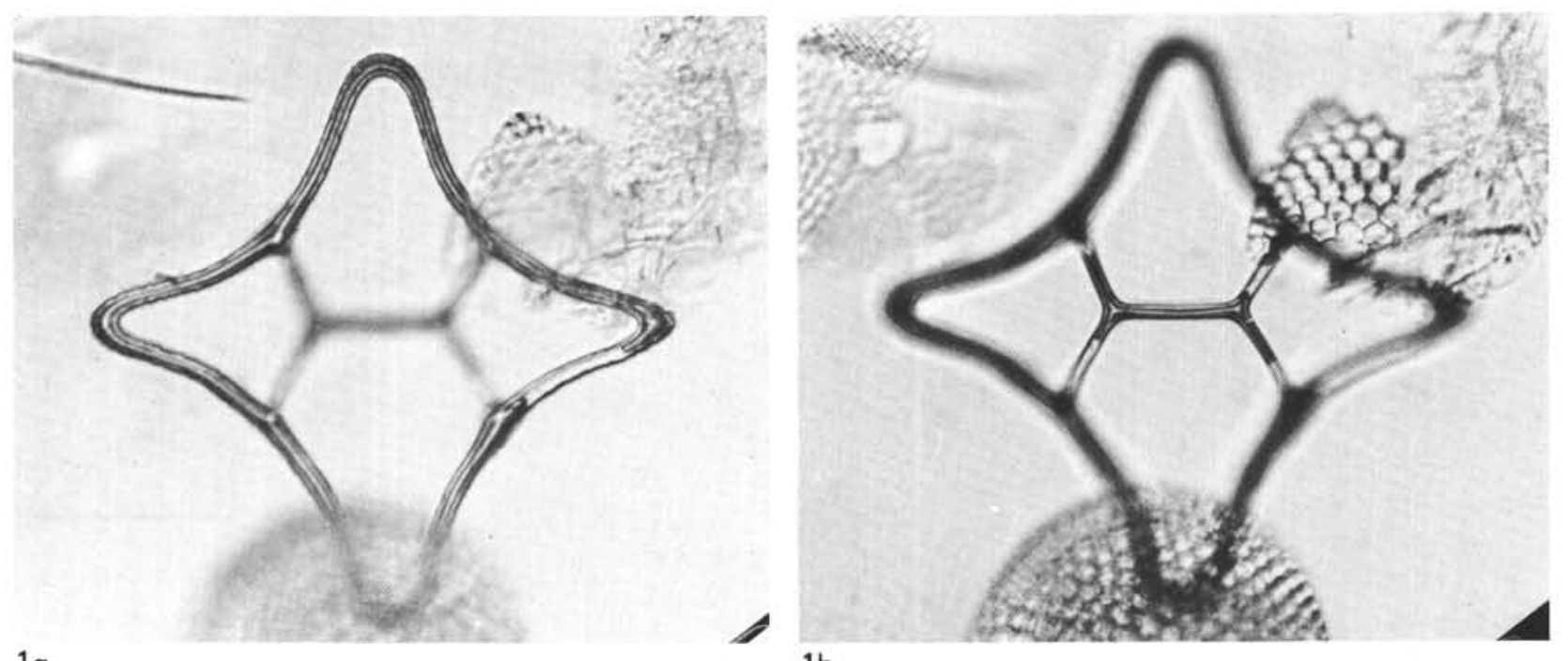

$1 a$

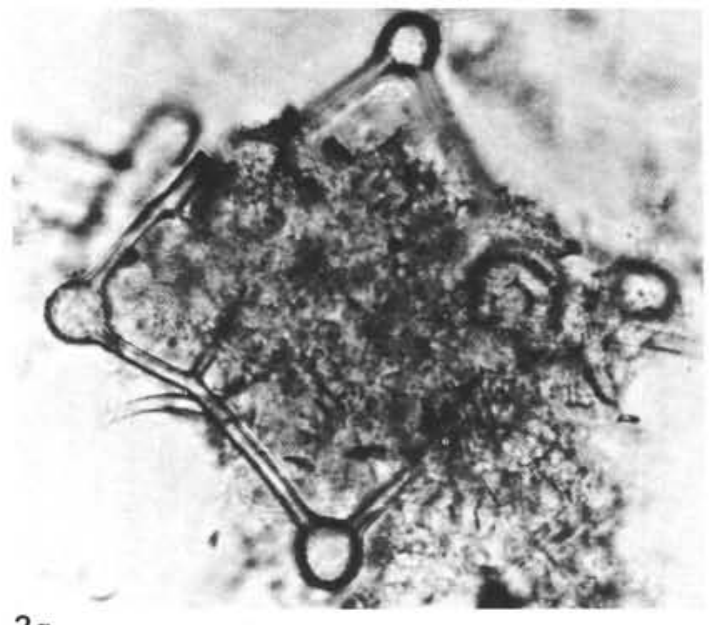

$1 \mathrm{~b}$

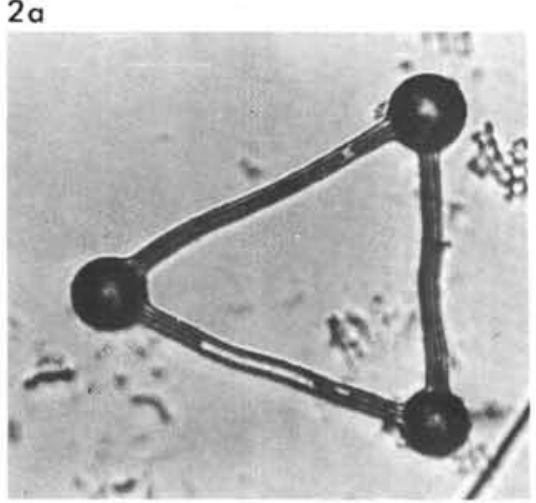

2b
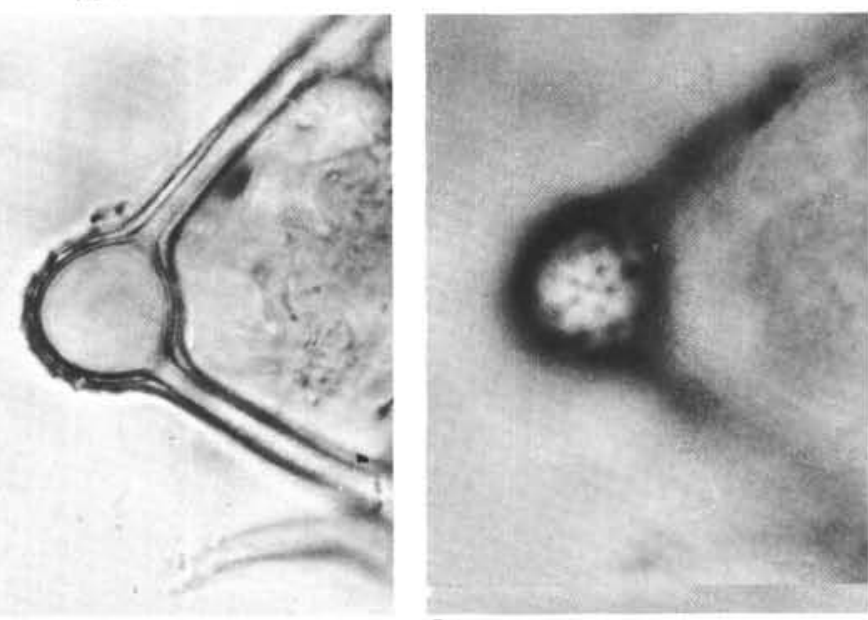

$2 c$
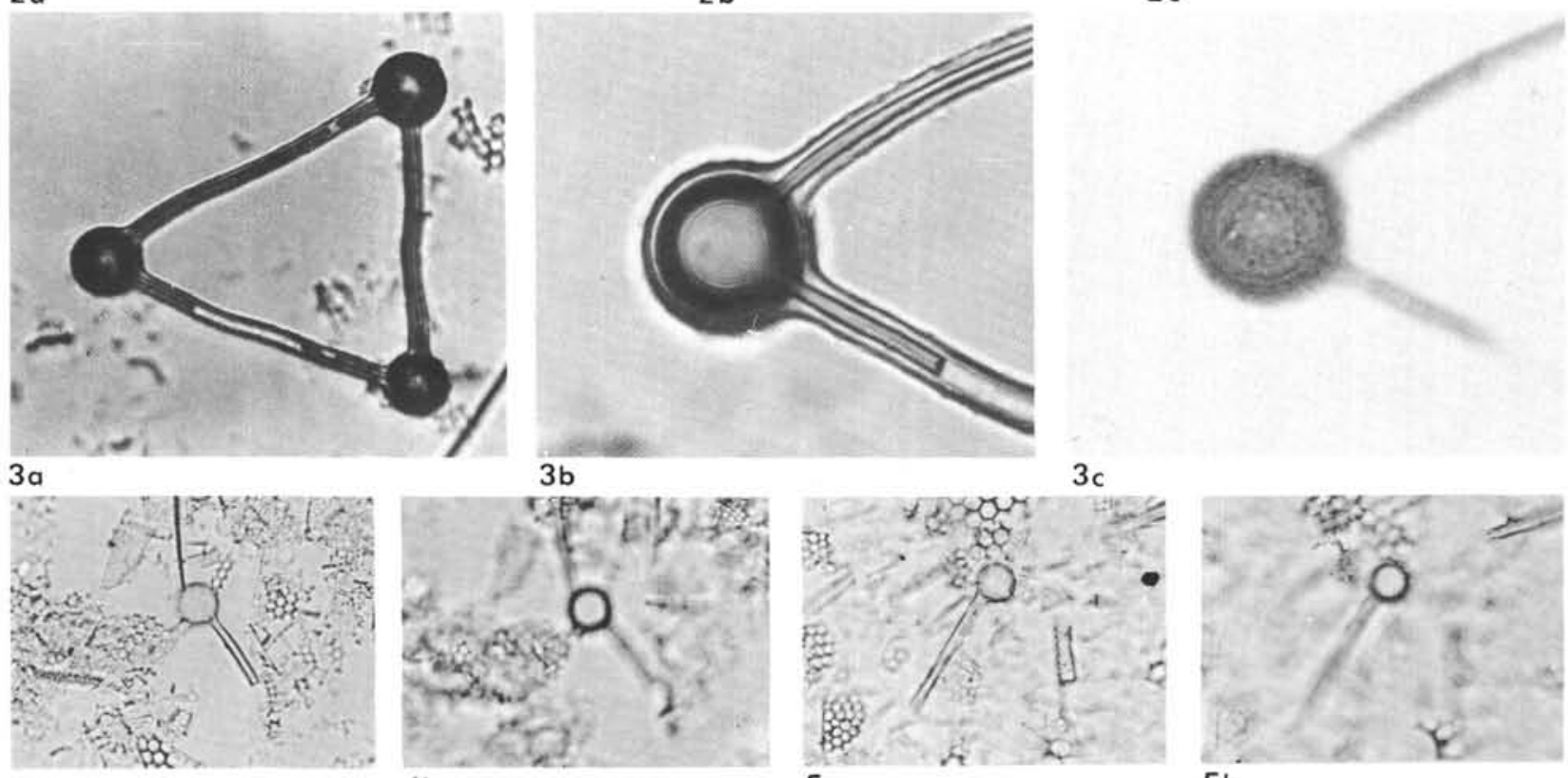

$4 b$
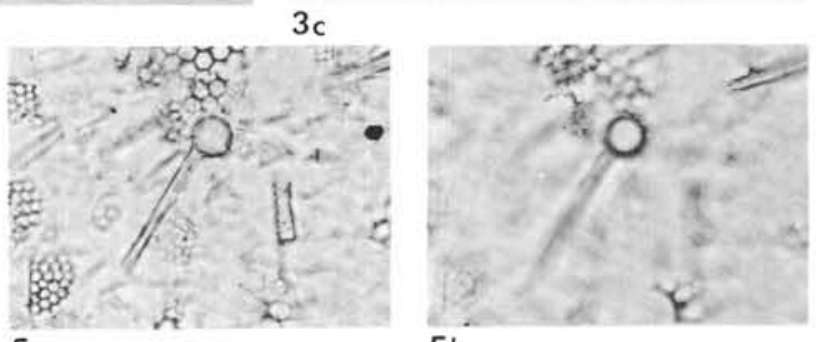

$5 a$

$5 b$ 


\section{PLATE 11}

(All specimens LM, and approximately $400 \times$.)

Figure 1 Mesocena concava Perch-Nielsen.

Sample 340-7-4, 145-146 cm;

Corbisema bimucronata Zone.

Figure $2 \quad$ Mesocena apiculata (Schulz).

Sample 338-13-1, 125-126 cm;

Naviculopsis navicula Zone.

Figure 3 Mesocena schulzii n. sp.

Holotype, SM.B 12798;

Sämple 338-16-5, 50-51 cm;

Naviculopsis navicula Zone.

Figure 4 Mesocena circulus Ehrenberg. Sample 348-11-5, 140-141 cm;

Mesocena circulus Zone.

Figure 5 Mesocena diodon Ehrenberg.

Aberrant specimen;

Sample 341-33-4, 130-131 cm;

Mesocena circulus Zone.

Figure 6 Mesocena $\mathrm{cf}$. diodon Ehrenberg.

Almost circular specimen with reduced spines;

Sample 338-8-4, 85-86 cm;

Corbisema triacantha Zone.

Figure 7 Mesocena diodon Ehrenberg.

Aberrant specimen;

Sample 348-17, CC;

Mesocena circulus Zone.

Figure $8 \quad$ Mesocena elliptica Ehrenberg.

Sample 348-11-1, 20-21 cm;

Mesocena circulus Zone.

Figure 9 Mesocena elliptica Ehrenberg.

Sample 338-14-3, 85-86 cm;

Naviculopsis navicula Zone.

Figure $10 \quad$ Mesocena $\mathrm{cf}$. elliptica Ehrenberg.

Sample 343-5-6, 35-36 cm;

Naviculopsis minor Zone.

Figure $11 \quad$ Mesocena diodon Ehrenberg.

Sample 338-7, CC;

Mesocena circulus Zone.

Figure 12 Mesocena apiculata (Schulz).

Sample 339-11, CC;

Naviculopsis biapiculata Zone.

Figure $13 \quad$ Mesocena schulzii n. sp.

Sample 399-10-2, 55-56 cm;

Naviculopsis biapiculata Zone.

Figure 14 Mesocena $\mathrm{cf}$. oamaruensis Schulz.

Sample 343-5-3, 100-101 cm;

Naviculopsis minor Zone. 
PLATE 11

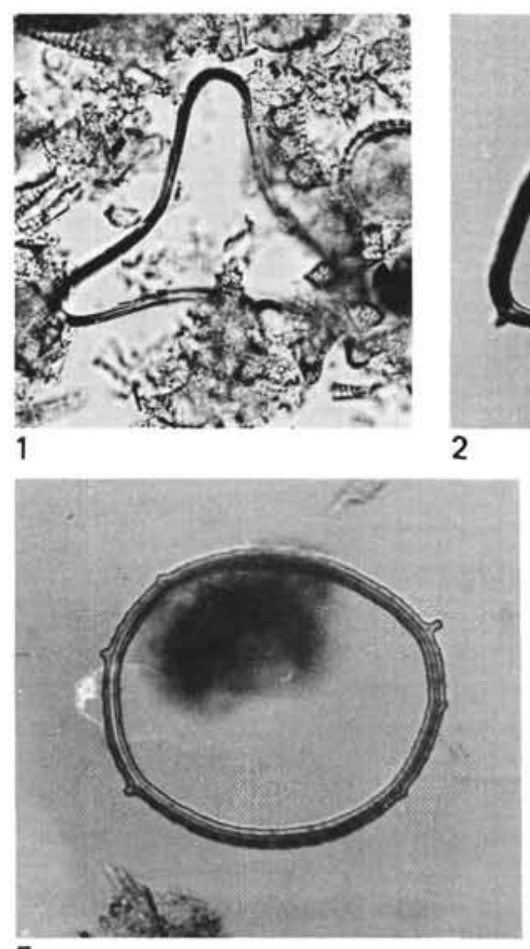

5

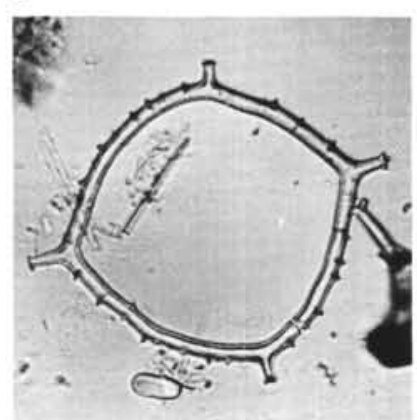

8

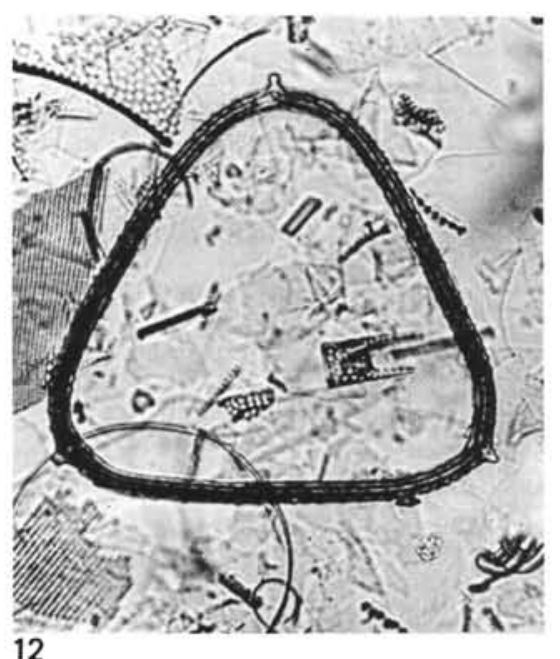

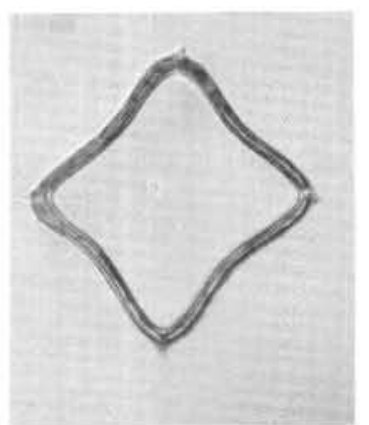

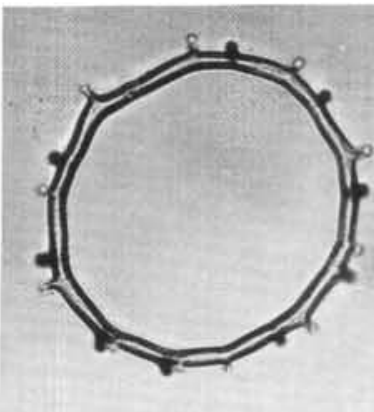

3

4

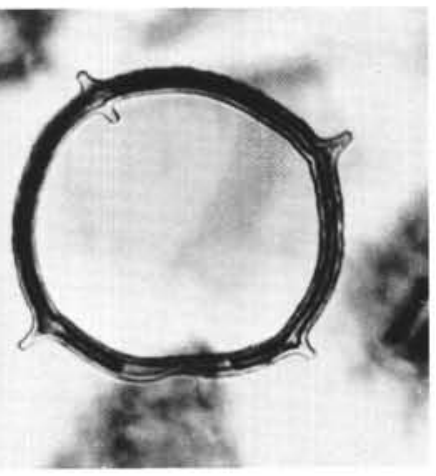

7

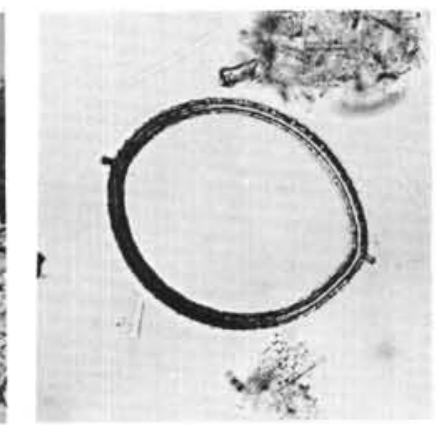

14
11
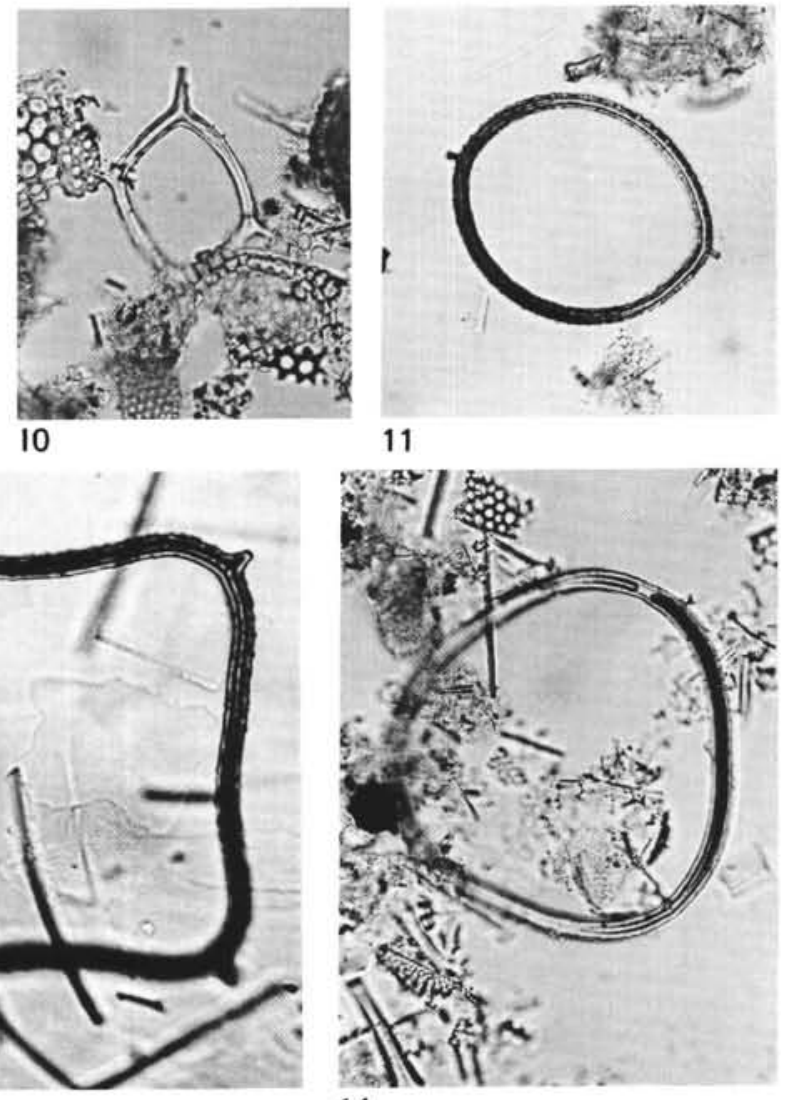
$x+50$.

10

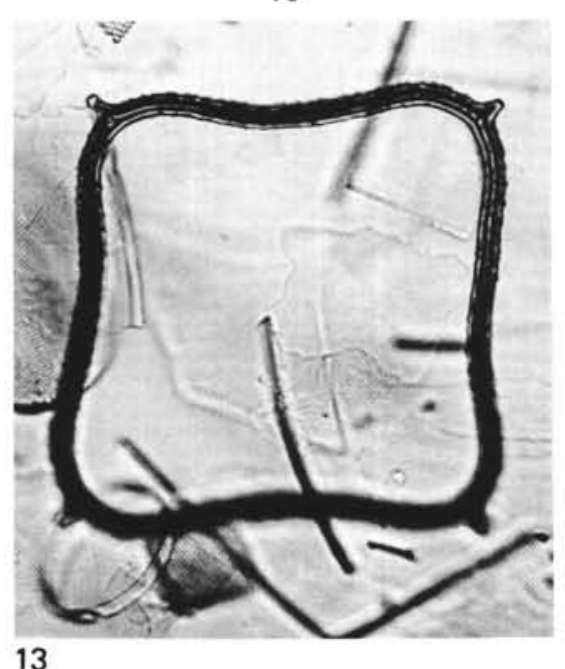

13 
PLATE 12

(All specimens LM, approximately $400 \times$.)

Figures 1,2 Naviculopsis ponticula Perch-Nielsen. Sample 340-11, CC;

Corbisema bimucronata Zone.

1. Distal side.

2. Side view of tilted specimen.

Figure 3 Naviculopsis cf. ponticula PerchNielsen.

Proximal side;

Sample 340-3-1, 140-141 cm;

Corbisema bimucronata Zone.

Figure $4 \quad$ Naviculopsis foliacea Deflandre.

Side view of slightly tilted specimen;

Sample 340-1-4, 115-116 cm;

Distephanus speculum Zone (reworked).

Figures 5-7 Naviculopsis sicca n. sp.

5. Holotype SM.B 12799, proximal side;

Sample 340-5-1, 110-111 cm;

Naviculopsis foliacea Zone (?).

6. Proximal side;

Sample 340-10-2, 100-101 cm;

Corbisema bimucronata Zone.

7. Side view;

Sample 340-7, CC.

Corbisema bimucronata Zone.

Figure $8 \quad$ Naviculopsis constricta (Schulz), broken specimen of Naviculopsis cf. ponticula Perch-Nielsen, and Dictyocha $\mathrm{cf}$. epiodon Ehrenberg.

Sample 339-7, CC;

Distephanus speculum Zone (reworked).

Figures 9-11 Naviculopsis aff. ponticula PerchNielsen.

Sample 338-29-1, 113-114 cm;

Corbisema bimucronata Zone.
9. Side view.

10. Distal view.

11. Tilted specimen.

Figure $12 \quad$ Naviculopsis cf. minor (Schulz).

Tilted specimen;

Sample 343-5-6, 110-111 cm;

Naviculopsis minor Zone.

Figure $13 \quad$ Naviculopsis biapiculata (Lemmermann).

Distal side;

Sample 338-21-1, 67-68 cm;

Naviculopsis biapiculata Zone.

Figure $14 \quad$ Naviculopsis cf. biapiculata (Lemmermann).

Distal side;

Sample 338-21-1, 67-68 cm;

Naviculopsis biapiculata Zone.

Figure $15 \quad$ Naviculopsis lata (Deflandre).

Proximal side;

Sample 338-17, CC;

Naviculopsis navicula Zone.

Figure $16 \quad$ Naviculopsis navicula (Ehrenberg).

Distal side;

Sample 338-15-1, 95-96 cm;

Naviculopsis navicula Zone.

Figure $17 \quad$ Naviculopsis iberica Deflandre.

Proximal side;

Sample 338-18, CC;

Naviculopsis lata Zone.

Figure 18

Naviculopsis quadratum (Ehrenberg).

Distal side;

Sample 338-13-3, 5-6 cm;

Naviculopsis navicula Zone. 


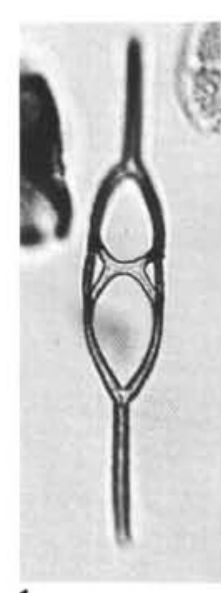

1
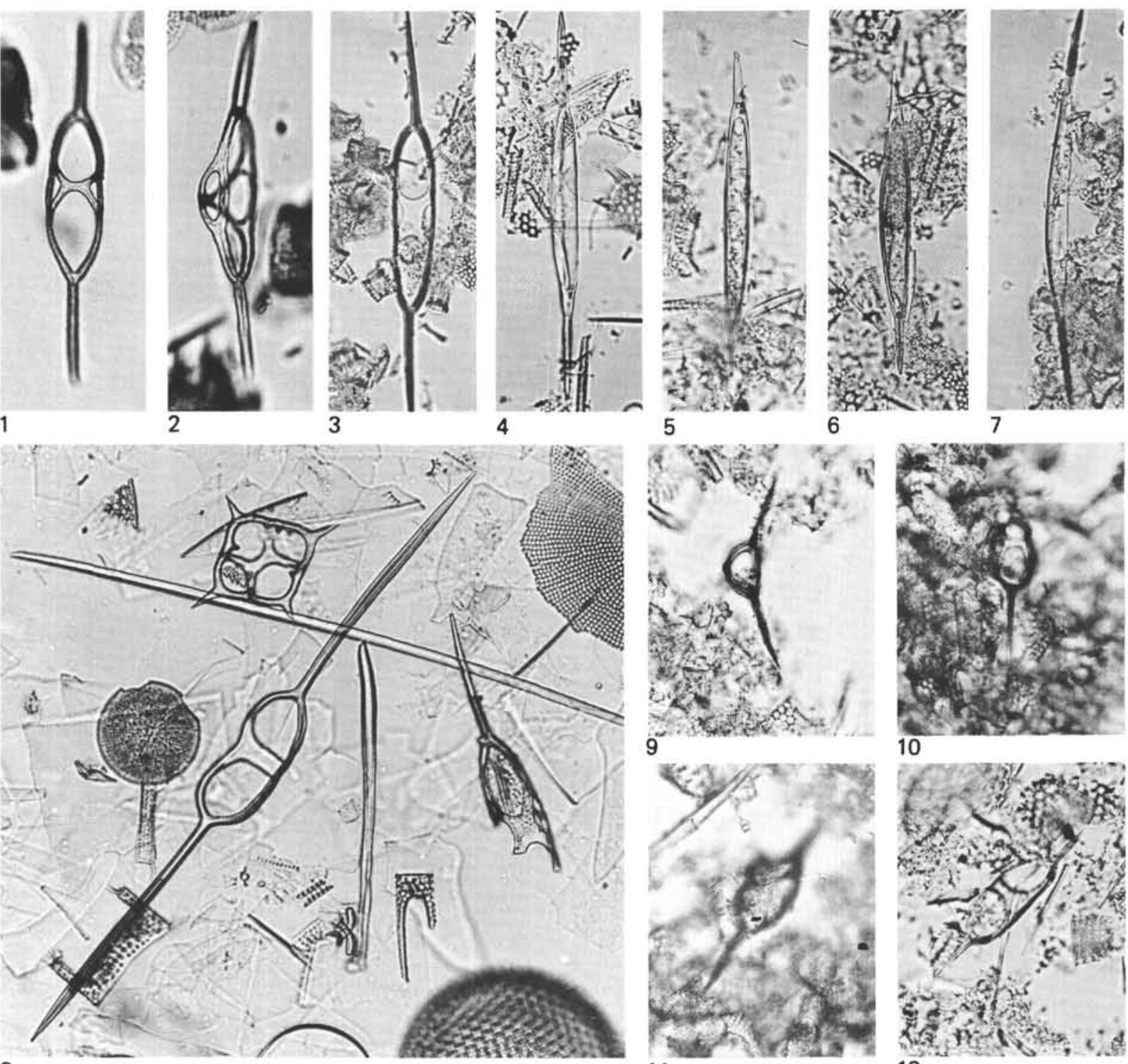

8

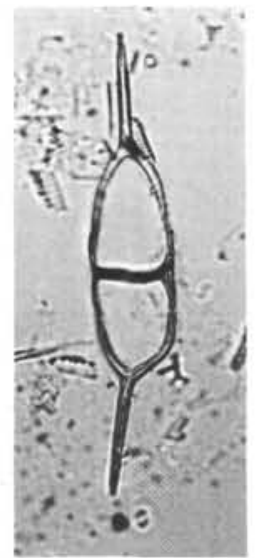

13

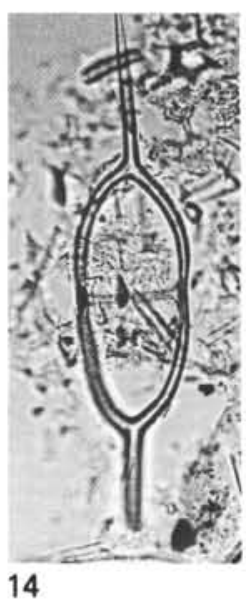

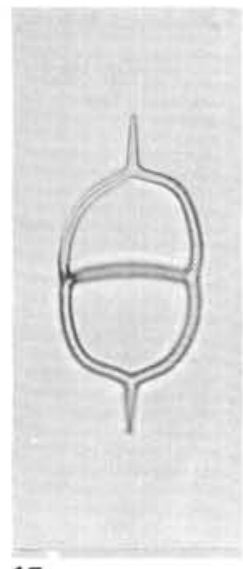

15
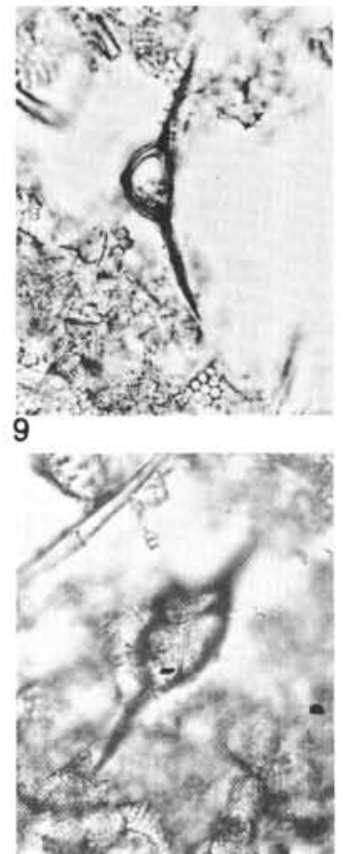

11

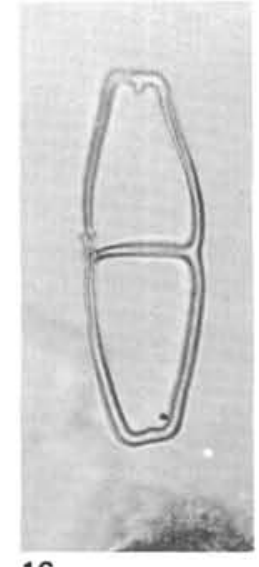

16

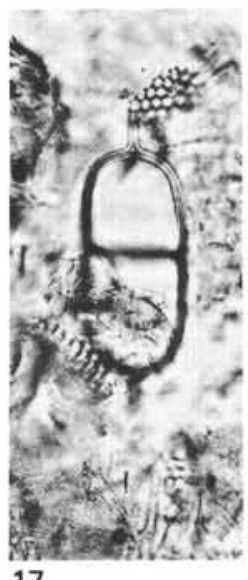

17

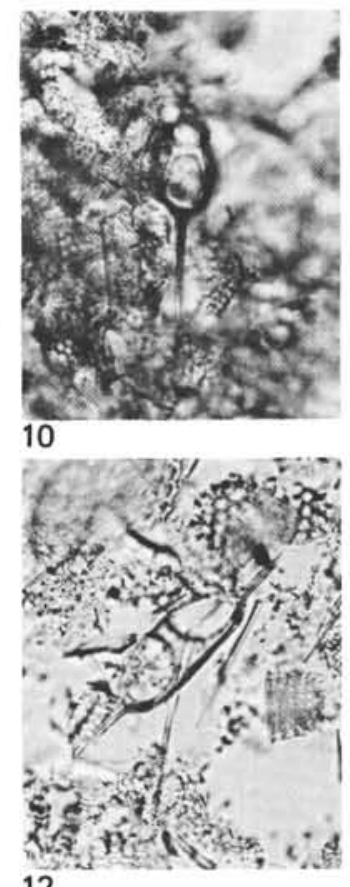

12

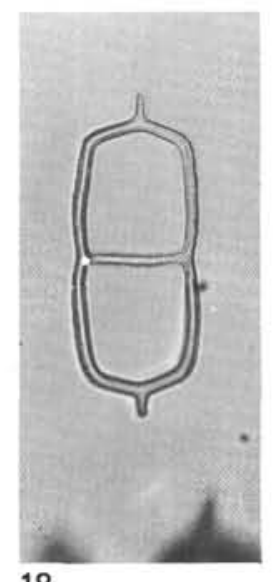

18 